NBER WORKING PAPER SERIES

\title{
IS IT WHOM YOU KNOW OR WHAT YOU KNOW? AN EMPIRICAL ASSESSMENT OF THE LOBBYING PROCESS
}

\author{
Marianne Bertrand \\ Matilde Bombardini \\ Francesco Trebbi \\ Working Paper 16765 \\ http://www.nber.org/papers/w16765 \\ NATIONAL BUREAU OF ECONOMIC RESEARCH \\ 1050 Massachusetts Avenue \\ Cambridge, MA 02138 \\ February 2011
}

The authors would like to thank Allan Drazen, Keith Krehbiel, Ken Shepsle, and seminar participants at the Korean Development Institute, the University of Chicago Booth School of Business, Columbia Graduate School of Business, University of California Berkeley Haas School of Business, University of Minnesota, the 2010 Wallis Conference on Political Economy, and Stanford Graduate School of Business. David Wood provided outstanding research assistance. Financial support from the Initiative on Global Financial Markets is kindly acknowledged. The views expressed herein are those of the authors and do not necessarily reflect the views of the National Bureau of Economic Research.

NBER working papers are circulated for discussion and comment purposes. They have not been peerreviewed or been subject to the review by the NBER Board of Directors that accompanies official NBER publications.

(C) 2011 by Marianne Bertrand, Matilde Bombardini, and Francesco Trebbi. All rights reserved. Short sections of text, not to exceed two paragraphs, may be quoted without explicit permission provided that full credit, including $\odot$ notice, is given to the source. 
Is It Whom You Know or What You Know? An Empirical Assessment of the Lobbying Process Marianne Bertrand, Matilde Bombardini, and Francesco Trebbi

NBER Working Paper No. 16765

February 2011

JEL No. D72,H7,P48

\begin{abstract}
$\underline{\text { ABSTRACT }}$
What do lobbyists do? Some believe that lobbyists' main role is to provide issue-specific information and expertise to congressmen to help guide the law-making process. Others believe that lobbyists mainly provide the firms and other special interests they represent with access to politicians in their "circle of influence" and that this access is the be-all and end-all of how lobbyists affect the lawmaking process. This paper combines a descriptive analysis with more targeted testing to get inside the black box of the lobbying process and inform our understanding of the relative importance of these two views of lobbying. We exploit multiple sources of data covering the period 1999 to 2008, including: federal lobbying registration from the Senate Office of Public Records, Federal Election Commission reports, committee and subcommittee assignments for the 106th to 110th Congresses, and background information on individual lobbyists. A pure issue expertise view of lobbying does not fit the data well. Instead, maintaining connections to politicians appears central to what lobbyists do. In particular, we find that whom lobbyists are connected to (through political campaign donations) directly affects what they work on. More importantly, lobbyists appear to systematically switch issues as the politicians they were previously connected to switch committee assignments, hence following people they know rather than sticking to issues. We also find evidence that lobbyists that have issue expertise earn a premium, but we uncover that such a premium for lobbyists that have connections to many politicians and Members of Congress is considerably larger.
\end{abstract}

Marianne Bertrand

Booth School of Business

University of Chicago

5807 South Woodlawn Avenue

Chicago, IL 60637

and NBER

marianne.bertrand@chicagobooth.edu

Matilde Bombardini

Department of Economics

University of British Columbia

997-1873 East Mall

Vancouver, BC V6T 1Z1

CANADA

and CIFAR and RCEA

and also NBER

matildeb@interchange.ubc.ca
Francesco Trebbi

University of British Columbia

1873 East Mall

Vancouver, BC, V6T1Z1

Canada

and NBER

ftrebbi@interchange.ubc.ca 


\section{Introduction}

At the intersection between the political and the economic spheres lays the lobbying industry. Trillions of dollars of public policy intervention, government procurement, and budgetary items are constantly thoroughly scrutinized, advocated, or opposed by representatives of special interests. The sheer relevance of the 4 billion dollars federal lobbying industry has become evident in any aspect of the 2008-2009 financial crisis, including emergency financial market intervention (the TARP), financial regulation, countercyclical fiscal policy intervention, and healthcare reform ${ }^{1}$. Notwithstanding its perceived fundamental role in affecting economic policy, very little systematic empirical research about the lobbying industry is available to economists and political scientists alike. For both sets of scholars what lobbyists do is a question without a definitive answer.

A large part of the academic theoretical literature on interest groups has painted the lobbying process as one of information transmission: informed interest groups send cheap or costly signals to uninformed politicians. ${ }^{2}$ This literature identifies a potentially welfare-enhancing role for the lobbying process, but has not produced substantial evidence in support of this mechanism. In this paper we take an indirect approach to this task by studying the intermediary between interest groups and policy makers, namely lobbyists. Stylized models of informational lobbying do not

\footnotetext{
${ }^{1}$ See for instance Birnbaum (2008): "A key provision of the housing bill now awaiting action in the Senate -- and widely touted as offering a lifeline to distressed homeowners -- was initially suggested to Congress by lobbyists for major banks facing their own huge losses from the subprime mortgage crisis[...]" [Vital Part of Housing Bill Is Brainchild of Banks, 6/25/2008, The Washington Post] or Pear (2009): "In the official record of the historic House debate on overhauling health care, the speeches of many lawmakers echo with similarities. [...] Statements by more than a dozen lawmakers were ghostwritten, in whole or in part, by Washington lobbyists working for Genetech, one of the world's largest biotechnology companies.” [In House Many Spoke With One Voice: Lobbyists', 11/15/2009, New York Times].

${ }^{2}$ Grossman and Helpman (2001) offer an exhaustive literature review. The basic idea is that interest groups, although known to be biased, are credible to the politician if their preferences are sufficiently aligned with the politicians' or the information they send is costly (or if it can be verified). Among the most prominent contributions are Crawford and Sobel (1982), Calvert (1985), Potters and Van Winden (1990, 1992, 1994), Austen-Smith (1992, 1993, 1994, 1995), Austen-Smith and Wright $(1994,1996)$. A few papers have looked at the interactions between the two tools available to interest groups (information transmission and campaign support), e.g., Austen-Smith (1995), Lohman (1995), and more recently, Bennedsen and Feldmann (2006).
} 
account for the presence of the lobbying industry as an intermediary, but understanding the role of the middlemen is important for two reasons. First it can offer some indirect evidence of how much of lobbying is indeed about information transmission. Second, given the large and growing size of the industry, ${ }^{3}$ lobbyists are likely to be more than just messengers, and understanding what they do should inform theoretical models.

With the goal of understanding what lobbyists do and why they are paid, this study considers two broad views of lobbying. Under one view, which resonates with the informational lobbying literature, lobbyists are experts who provide information to legislators and help guide their decision-making process. Such expertise might be particularly valuable when one considers that legislators themselves may have neither the technical background nor the time to delve into the detailed implications of all the pieces of legislation they are debating. This view is also maintained by the American League of Lobbyists, which on its official website states "Lobbying is a legitimate and necessary part of our democratic political process. Government decisions affect both people and organizations, and information must be provided in order to produce informed decisions. ${ }^{4}$

This expertise view of lobbying stands in contrast with the view, held by many in the media and on the street, that lobbyists' main asset is not what they know but instead whom they know. ${ }^{5}$ In interviews with insiders, McGrath (2006) reports "There are three important things to know about lobbying: contacts, contacts, contacts." What is valuable under this alternative view is not lobbyists' expertise, but instead their access to various members of Congress through personal, and possibly also financial, connections. ${ }^{6}$ This perspective does not completely rule out a flow of

\footnotetext{
${ }^{3}$ See Appendix Table A1

${ }^{4}$ http://www.alldc.org/publicresources/lobbying.cfm

${ }^{5}$ See Salisbury et al. (1989) for an early discussion and test based on surveys of lobbyists and Apollonio, Cain and Drutman (2008, section B), Drutman (2010) for a recent discussion.

${ }^{6}$ It is important to notice, however, that such a view of lobbyists does not necessarily imply (even though it could be associated with) a quid-pro-quo aspect of the lobbying process. According to the "quid-pro-quo" view, politicians either modify their electoral platform or implement policies when in office and receive in exchange valuable campaign contributions that are used more or less directly to sway voters. A large number of models with different
} 
information from interest groups to politicians, but excludes that lobbyists are the source of expertise.

Sorting out these two views of lobbying is important because they differ in their implications for the quality of the legislative output. With very few exceptions, mostly limited to specific congressional studies, systematic evidence has eluded both political economists and political scientists. ${ }^{7}$ Moreover, many of the existing studies report the lobbyists' point of view on what lobbyists do, being based on surveys of insiders (Esterling, 2004; Heinz et al., 1993), a potentially biased representation relative to what lobbyists actually do.

In this paper, we combine multiple data sources that help us paint a picture of the lobbying process over the last decade. This includes lobbying records as maintained by the Senate Office of Public Records (SOPR), lobbyists’ campaign contribution donations from the Federal Election Commission, and biographical information for a subset of lobbyists that we collect from an online registry.

We first document basic facts about the expertise of lobbyists and connections between lobbyists and politicians. We build measures of expertise by looking at the entire set of lobbying records that are associated with a given lobbyist and evaluating how narrow or broad the range of issues a lobbyist's name is associated with is. While we cannot directly observe lobbyists' contacts with politicians, we propose to proxy for it with a count of the number of campaign contributions that lobbyists make to various politicians and Members of Congress. ${ }^{8}$ We remain agnostic as to what

objectives share this fundamental "quid-pro-quo" approach. A non-exhaustive list of papers that have employed this approach includes Austen-Smith (1987), Baron (1989), Baron (1994), Snyder (1990), Snyder (1991), Grossman and Helpman (1994, 1995, 1996), Dixit et al. (1997) and Besley and Coate (2001). Bombardini and Trebbi (2009) explore the interaction between monetary support and direct votes promised by interest groups but essentially maintain the quid-pro-quo approach. This strand of the literature has received a lot of attention from the empirical point of view, in particular in its application to the literature on endogenous trade policy (Goldberg and Maggi, 1999; Gawande and Bandyopadhyay, 2000, Bombardini, 2008).

${ }^{7}$ Early related contributions include Langbein (1986), Salisbury et al. (1989), Wright (1990), Heinz et al. (1993).

${ }^{8}$ Wright (1990) is among the first to report a positive correlation between lobbying contacts and campaign contributions, while Ainsworth (1993) underscores that "indeed, there is evidence that campaign contributions appear to be most useful as predictors of access (Grenzke 1989; Herndon 1982; Langbein 1986).” 
these connections represent and prefer to keep the view that they proxy for any kind of contact between lobbyists and politicians. According to many scholars campaign contributions are simply a way to gain access to time-constrained politicians, "a chance to 'tell their story"” (Sabato, 1985). The presence of such access costs is compatible with an informational view of lobbying, where those groups that gain access communicate useful information to the politician. But such connections could also represent personal relationships where the lobbyist's expertise plays no role.

We first establish some key trends in the data. In particular, we show that the steady growth in the size of the lobbying industry over the last decade has been paralleled with an also somewhat steady growth in the number of connections between lobbyists and politicians. Interestingly, the growth in lobbying has been almost exclusively driven by external lobbying, not in-house lobbying, with external lobbyists being those that maintain generally more ties to politicians (at least through individual campaign contributions). Furthermore, while connections to politicians appear on the rise among all types of lobbyists, the prevalence of issue expertise among lobbyists has been quite stable over the last decade.

An important facet of the current media and policy debate surrounding lobbying has centered on the revolving door between positions on the Hill and positions in lobbying. On the one hand, revolving door lobbyists could be a key source of issue expertise, and restricting the ease with which these individuals can move from offices in Congress or government to the lobbying sector may result in the loss of valuable knowledge. On the other hand, this group might be particularly powerful in influencing current lawmakers due to overlapping social networks. Contrary to the first view, we establish unambiguously that revolving door lobbyists are not those with deeper issue expertise; what distinguishes them from other lobbyists is a much higher number of connections to politicians and current lawmakers.

Simply counting the number of legislators a given lobbyist makes campaign contributions to obviously falls short of establishing that such connections play a role in the lobbying process. Indeed, a lobbyist may give campaign contributions to a set of politicians for reasons that are purely personal, and unrelated to his or her professional activities. 
We therefore next dig deeper into understanding whether and how connections between lobbyists and politicians (through campaign contributions) matter for their job. We show that whom lobbyists make campaign contributions to is systematically related to what they work on. Specifically, a lobbyist that works on, say health care-related issues is systematically more likely to be connected (through campaign contributions) to legislators whose committee assignments include health care. Lobbyists’ donations are not given for purely personal reasons. The evidence rather hints at campaign contributions proxying for the lobbying activity of lobbyists, likely a tell-tale of the otherwise unobservable connection between lobbyists and congressmen.

In what we see as one of the main contributions of the paper we attempt to disentangle whether whom or what lobbyists know drives their activity. We find evidence that lobbyists switch issues in a predictable way as the legislators they were previously connected to through campaign donations switch committee assignments. Hence, for example, a lobbyist that is connected to a legislator whose committee assignment includes health care in one Congress is more likely to cover defense-related issues in the next Congress if the legislator he or she is connected to is reassigned to defense in the next Congress. In other words, part of what lobbyists do appears to be a function of whom they know and have access to, rather than what they know. We however also see some evidence of lobbyists establishing connections to politicians that are entering a lobbyist's prior area of activity due to a change in committee assignment. Hence, lobbyists' connections operate as an exogenous driver of what issues they work on, but are also in part endogenously created to facilitate the transmission of knowledge and expertise to the relevant lawmakers. We view the first type of connections as representing underlying long-standing ties, while the second type reflects temporary links established in order to communicate the relevant information.

In a complementary analysis, we ask what makes lobbyists more valuable, using the dollar value attached to the lobbying reports. We investigate what makes hiring the lobbying team on a given report expensive and find that, while having at least an expert on the team is important, having connected lobbyists brings twice as large a premium. This confirms the relevance of the first type of connections discussed above: the positive premium we estimate for connected lobbyists suggests that some political contributions by lobbyists might be best understood as a 
manifestation of deeper, harder to replicate, personal ties. The barriers to entry into establishing the type of connections of politicians we measure in the data (campaign contributions below $\$ 2,400$ ) are very low compared to the premium they command; so what earns a premium is the relationship between lobbyists and politicians that certain campaign contributions embody. Also, to approximate the value of an individual lobbyist, we use some residual measure of the dollar value of the lobbying reports he or she is assigned to. Is the lobbyist's value coming from his or her expertise in specific technical areas? Or is it coming from the connections that the lobbyist maintains with politicians and lawmakers? This additional analysis confirms that connections rather than issue expertise might be the relatively scarce resource lobbyists are bringing to the table. Finally, we check for changes in premia associated with "issue cycles", that is whether returns respond to an issue becoming popular. We find no evidence that the return of a specialized lobbyist moves with the issue cycle, and it seems that most of the adjustment during a boom is through additional entry of non-specialists who start lobbying on that issue. Analogously to the issue cycle, we check for evidence of "political cycles" in the returns to lobbyists, and find an increase in the returns to lobbyists associated to a given party when that party is in a position of power.

Can our findings rule out that lobbyists are experts or that they convey information? The evidence points to a relatively small role played by technical expertise, ${ }^{9}$ but is consistent with a scenario where lobbyists connected to a given politician are valuable because they have a deep knowledge of that politician's constituency, ${ }^{10}$ and have built a relationship of trust and credibility vis-à-vis that politician. They could be communicating information, but their returns are seemingly more related to the complementary asset they bring to the table and to their role as intermediaries in the transmission of information.

\footnotetext{
${ }^{9}$ Incidentally, it is easy to verify that large lobbying firms like Patton Boggs LLP or Cassidy and Associates employ very few individuals with background that points to specific technical training, even when the lobbying covers technical issues such as biotechnology or nuclear energy. See Table A-3 where report information extracted from the biographies of lobbyists posted online by the lobbying firms.

${ }^{10}$ Hansen (1991) suggests that "Lawmakers operate in highly uncertain environments. They have an idea of the positions they need to take to gain reelection, but they do not know for sure. Interest groups offer to help . . . They provide political intelligence about the preferences of congressional constituents.”
} 
The rest of the paper proceeds as follows. We first describe the pool of lobbyists and present some summary statistics on their professional background (Section 2). We then define our measures of expertise and connections, and discuss trends in those over the last decade (Section 3). Section 4 briefly looks into which specific asset lobbyists are particularly endowed with (issue expertise or connections). We then move to more detailed tests of whether and how connections to politicians affect what lobbyists work on (Section 5). Section 6 presents our analysis of the premia associated with issue expertise, connections and past experience on the Hill or in government offices, along with an analysis of returns over "issue cycles" and "political cycles”. We conclude in Section 7.

\section{The Lobbyists}

We use lobbying registration information from the Senate Office of Public Records (SOPR) to build a database of lobbyists for the period 1999 to $2008 .{ }^{11}$ Each of the records filed with SOPR contains not only the name of the reporting firm and the name of the client firm or organization, but also the names of the individual lobbyists that were involved in this specific lobbying case. It is therefore possible to construct, starting with the lobbying records, a database that contains the names of all lobbyists that were active at the federal level over the last decade. ${ }^{12}$ We identify

\footnotetext{
${ }^{11}$ Data on lobbying expenditures from the Senate Office of Public Records has been previously employed in a very small number of papers, some of which utilize only a very limited subset of the available information. Ansolabehere, Snyder and Tripathi (2003) focus on the link between campaign contributions and lobbying and show that the two are correlated, consistently with a view that campaign contributions are a way for interest groups to buy access to politicians. Once access is gained lobbyists have a chance to voice the interests of their clients. The paper also shows that the pattern of campaign contributions varies according to the intensity of lobbying of a given group. Baumgertner and Leech (2001) offer a partial analysis of the distribution of lobbyists across issues, finding high concentration in some issues and very low in others. Bombardini and Trebbi (2008) study trade association lobbying in international trade, while Igan, Mishra and Tressel (2009) and Mian, Sufi and Trebbi (2010) study lobbying by home mortgage firms during the US housing market expansion. In an interesting and related paper Blanes-i-Vidal, Draca, and Fons-Rosen (2010) employ SOPR data to assess the drop in revenues occurring to a subset of lobbyists with past experience as senatorial aides when their Senator leaves office.

${ }^{12}$ Any type of information provision and research activity related to contacts to politicians requires registration. From the Office of the Clerk, Lobbying Disclosure Act Guidance: 'Lobbying activity is defined in Section 3(7) as "lobbying contacts and efforts in support of such contacts, including ... background work that is intended, at the time it is performed, for use in contacts, and coordination with the lobbying activities of others." If the intent of the work is to support ongoing and future lobbying, then it would fall within the definition of lobbying activities.' Any
} 
about 37,000 individual lobbyists between 1999 and 2008. The Center for Responsive Politics lists on average 13,024 unique lobbyists per year between 1998 and 2010, varying from 10,404 in 1998 to 14,869 in 2007.

The SOPR data also allows us to separate the lobbyists into two sub-groups based on whether they are in-house lobbyists (these are the cases where the registering firm is the same as the client firm in the lobbying report) or whether they work for a lobbying firm that is representing another organization (the cases where the registering firm is different from the client firm). In what follows, we refer to the former group as the "internal" (or in-house) lobbyists and to the latter group as the "external” lobbyists. ${ }^{13}$ We can also use the SOPR data to compute, for each lobbyist*year observation: number of years of experience (with the caveat of the right-tail truncation), and number of records the lobbyist name is attached to in a given year. Furthermore, we can compute how many years a given lobbyist appears as active over the sample period (10 years at most).

We rely on www.lobbyists.info to obtain additional time-invariant background information about the lobbyists we identify in the lobbying records. This website, which was originally derived from the directory "Washington Representatives" and is maintained by Columbia Books \& Information Services (CBIS), is the best information source we are aware of for federal lobbyists. Often included on the website are short biographies that allow us to further profile the lobbyists. In particular, we searched for specific strings in this online directory to build a set of background experience indicators, such as whether a lobbyist has "Republican” or "Democrat" associations, whether the lobbyist has "House" or "Senate" or "White House" experience, or whether the lobbyist is referred to as "Hon." (the explicit title for former members of

individual paid to perform such activities in excess of $20 \%$ of his work time and who establishes more than one lobbying contact with a politician over a quarter has to register as lobbyist.

${ }^{13}$ If a lobbyist ever appears as both internal and external in a given year, we arbitrarily categorize her as external in that year. When we collapse the panel data at the lobbyist level, we also categorize as external a lobbyist that appears both as internal and external in different sample years. 
Congress). ${ }^{14}$ Not all lobbyists identified in the SOPR data appear on www.lobbyists.info; in practice, we found about 14,000 of the 37,000 lobbyists identified in the SOPR data in www.lobbyists.info. ${ }^{15}$

Table 1 summarizes the lobbyist-level data; the unit of observation is a lobbyist and all lobbyists are equally weighted to compute these summary statistics. About 40 percent of lobbyists work in-house. The average lobbyist appears in the data for about four years and has nearly two years of experience; he/she is associated with about 5 lobbying records in a typical active year. Among those lobbyists that we can find in www.lobbyist.info, 97 percent have some biographical information associated with their name. Among those, about 11 percent have some association to the Republican party and about 9.8 percent to the Democratic party. A bit more than 1 percent of the lobbyists for which we could find biographical information are former members of Congress. ${ }^{16}$ About 2 percent of the biographies mention some experience in the White House. There is also a large representation of former "aides" (11 percent) and individuals with experience in senators' offices (around 10 percent). ${ }^{17}$

Table 2 shows how lobbyists' background has changed over the years. The most dramatic change over time appears to be in the share of in-house lobbyists, which has declined from nearly 60 percent at the beginning of the sample period to less than 40 percent by the end. In

\footnotetext{
${ }^{14}$ To be specific, we first downloaded the whole directory by running a blank search on the database. Second, we run a series of searches conditional on matching certain strings of text in the bio, like "senate" or "house" or "Democrat", etc. Third, we merged together every single list against the whole set of lobbyists, generating a dummy conditional on the matching being successful (i.e. you get Democrat=1 if you are in the output of that search). Prior to converging on this coding method, we run about 200 manual spot searches to check that the method was producing reliable results.

${ }^{15}$ Maybe not surprisingly given that we downloaded the directory information in 2009, we are more successful at identifying lobbyists that were active in the later part of the sample period than lobbyists that were active at the first few years. The match rate varies between the upper 30 percents at the beginning of the period to the mid 60 percents towards the end. Those lobbyists that can be identified in www.lobbyists.info typically have more years of experience and are associated with more lobbying records in each active year. See Table 1.

${ }^{16}$ A majority of those are ex-House Representatives, and about equal shares come from the right and left wings of the political spectrum (.7 percent and .6 percent, respectively).

${ }^{17}$ Of course, these two groups can overlap.
} 
fact, as can be seen in Appendix Table A1, the rapid growth in total lobbying expenses over the last decade (about a 30 percent increase) can be almost exclusively accounted for by a growth of external lobbying, which doubled over the sample period. In-house lobbying instead, while up in the first part of the last decade, was back down to its starting level by the end of the decade. While this is not the central topic of this paper, this does suggest that building an understanding of the recent growth of lobbying expenses should start with identifying the key drivers of the external lobbying process. In what follows, we make sure to present separate analysis for external and internal lobbying. ${ }^{18}$

Now, despite an active media coverage that might have suggested the contrary, there is no systematic evidence (at the individual lobbyist level at least) that the revolving door is more open today than it was in the past. The share of active lobbyists in 2008 that were, for example, former members of Congress, is smaller by 2008 than it was in 1999. Similarly, there are fewer (in percentage terms) active lobbyists in 2008 that have experience in the White House or experience as "aide" or in a senate office than there was in 1999. Much of the decline in the share of revolving door lobbyists appears to be concentrated in the second half of the sample period.

\section{Expertise and Connections}

\section{A. Expertise}

One of the prevailing views of what lobbyists do is that they support overly burdened legislators (and regulators) with much needed expertise on often complicated topics, and therefore provide valuable guidance in the lawmaking and rulemaking processes. In this section, we construct measures of expertise (or specialization) at both the lobbyist and lobbying firm levels; we also describe trends in those measures over time.

\footnotetext{
${ }^{18}$ A widely held view of internal lobbyists is of watchdogs monitoring the day-to-day activity of Congress flagging potential issues of interests for their company (and calling in the professional external lobbyists when necessary). Such activity does not appear to require any particular expertise or connections. Hrebenar and Morgan (2009) highlight how many of the in-house lobbyists are also not full-time lobbyists and often volunteer or amateur lobbyists, especially with regard to groups dealing with moral, environmental, or religious issues.
} 
We propose to measure the extent to which lobbyists are experts by assessing how narrow or broad the range of issues they are assigned to is. This can be done with the SOPR data. Associated with each report is a checklist of all the issues a given report is covering. (The full list of issues is reported in Appendix A1. A sample report is presented in Appendix A2.) More precisely, consider a report $r$ at time $t$. The report lists a number of issues $I_{r t}$ (where $I_{r t}$ is bound between 1 and 76 possible issues), the name of all $L_{r t}$ lobbyists employed and the dollar amount paid for lobbying services on those issues $I_{r t}$ at time $t, V_{r t}$. Let us assume that the report value is divided symmetrically across all lobbyists, so that the service of each lobbyist $l$ in the report is valued $V_{l r t}=\frac{V_{r t}}{L_{r t}}$. If we impute this value symmetrically to all issues, then the dollar amount for issue $i$ and lobbyist $l$ on report $r$ at time $t$ is $V_{i l r t}=\frac{V_{l r t}}{I_{r t}}$. If lobbyist $l$ works on $R_{l t}$ reports then we can indicate by $V_{i l t}$ the value of lobbying on issue $i$ so that $V_{i l t}=\sum_{r=1}^{R_{l t}} V_{i l r t}$. We sum $V_{i l t}$ across all active years for lobbyist $l$ to obtain $V_{i l}$. Using these dollar values as weights, we compute for each lobbyist $l$ an issue-based Herfindahl Index (HHI) that measures how concentrated this lobbyist's assignments are across all possible issues $I$ :

$$
\mathrm{HHI}_{l}=\sum_{i=1}^{I}\left(\frac{V_{i l}}{V_{l}}\right)^{2}
$$

where $V_{l}=\sum_{i=1}^{I} V_{i l}$. Hence, a lobbyist whose name is attached to only one issue across all lobbying records over the last decade would be assigned an HHI of 1. As a complementary measure, we also generate a dummy variable called "specialist" that equals 1 if a lobbyist spends (in dollar terms) at least a quarter of his assignments in each active year on the same issue. We call a "generalist" a lobbyist that never spends (i.e. in no active year) more than a quarter of his assignments on the same issue.

The measures of specialization we propose are subject to both downward and upward sources of bias. First, there are typically multiple lobbyists assigned to a given lobbying report (the mean across reports is 3 ; the median is 2), and it is possible that not all the lobbyists whose names is listed on a report cover all the issues associated with the report. Because we do not observe when 
such within-report specialization occurs, we cannot account for it; this will lead us to underestimate how specialized a given lobbyist is. Second, because lobbyists typically do not work for many years in our data (the average number of active years is about 4), our proposed specialization measures may mistakenly classify as specialists those lobbyists that appear on only a very limited number of reports or work for a very limited number of years; this will lead us to overestimate the degree of specialization.

Table 3 presents means and trends over time in the average level of expertise in the unbalanced panel of lobbyists (e.g. a panel that includes only lobbyists in the years in which they are active). All lobbyist-year observations are equally weighted in the construction of these statistics. Across all years and all lobbyists (Table 3, Panel A), our expertise measures lead us to qualify about a quarter of lobbyists as specialists and about another quarter as generalists; the average issuebased HHI in the lobbyist panel is .34. There is no monotonic trend over time in the share of specialists or the HHI measure; if anything, the share of specialists seems to have gone down in the first half of the decade and back up in the second half. Panel B replicates the same statistics but restricts the panel to the subset of lobbyists that appear in the lobbying data for at least 4 years. As we had anticipated, the share of specialists drops somewhat in this subsample (19 percent across all years, respectively); the HHI measure is basically unchanged. In this subsample, we again see no systematic trend in expertise over the sample period.

Panels C and D report means and trends in specialization for external and internal lobbyists, respectively. External lobbyists are more likely to be specialists than internal lobbyists (mean of .3 vs. .2 across all years) and less likely to be generalists (mean of .13 vs. .4 across all years). In neither of these two subsamples do we observe systematic trend in issue expertise over time.

Figure 1A displays the distribution of the share of specialists across lobbying entities for the entire sample period. Our motivation for looking at such distribution is the possibility that a subset of lobbying firms might want to differentiate by “specializing in specialization.” Under this view, one might expect multiple modes when plotting the distribution of the specialist share across firms. We can easily compute this firm-level measure from the SOPR data as it links 
every lobbyist to the firm he or she is working for. ${ }^{19}$ The distribution of specialist share in professional lobbying organizations does appear bimodal, with a large mode around 0 and another much smaller mode around 1; the distribution for in-house lobbying teams does not display any mode at 1 .

\section{B. Connections}

In contrast with the view that lobbyists add issue expertise to the law- and rulemaking process is the view that lobbyists' main asset is their social network and, in particular, their personal relations to lawmakers. In the words of Hon. John Boehner "many of the lobbyists who enter our offices every day to represent their clients are, for all practical purposes, complete mysteries to us. Yet for the House to function, some degree of trust is necessary. Many lobbyists are of the highest integrity and feel as much of a duty to the House as a democratic institution as they do to their clients. But there's every incentive for those with more questionable ethics to shortchange us and the House. And absent our personal, longstanding relationships, there is no way for us to tell the difference between the two." 20

While investigative journalism has given us detailed accounts of relationships between legislators and lobbyists, these accounts only provide spotty pictures that cannot be generalized to the entire lobbying industry or lawmaking group. A clear difficulty in terms of painting a more complete picture is to build a systematic measure of connections. We propose to exploit information on campaign contributions lobbyists make to politicians to construct such a measure. Specifically, we search the campaign contribution records kept by the Federal Election Commission to identify all campaign contributions made by the lobbyists identified in the SOPR data. For each lobbyist, we can measure whether he or she has made at least one contribution to a

\footnotetext{
${ }^{19}$ In computing this measure, we weigh each lobbyist-firm observation by the number of records he or she was listed on across the entire sample period and restrict ourselves to the sample of organizations that employ at least two lobbyists over the entire sample period.

${ }^{20}$ John Boehner: For a Majority That Matters (January 9, 2006).
} 
campaign over the sample period $^{21}$; we can count a lobbyist's average number of contributions in any given Congress; and we can also tag those lobbyists that make "many" campaign contributions in any given Congress (we arbitrarily define “many” as five or more).

One clear concern about this measure is that it may systematically miss strong connections between lobbyists and politicians, as such connections may not require campaign contributions. To build some sense of how much of a concern this is, we considered a group of 50 lobbyists with family members serving in Congress (source: Public Citizen, 2007). There is arguably no connection stronger than family ties. Were campaign contributions just a weak substitute for closer ties, we would expect to see no connections as we measure them (e.g. through political donations) between these lobbyists and their family members in Congress. In fact, we found that 30 percent of these 50 lobbyists make campaign contributions to their family members. As an additional check, we also made use of a list of 21 lobbyists and public affairs consultants with strong ties to Republican Congressman John A. Boehner published by the New York Times ${ }^{22}$. Cross-checking with FEC individual campaign contribution data we were able to recover 52 percent of the connections. Hence, our connection measure, while certainly noisy, will arguably correlate with strong ties. $^{23}$

Another concern about this measure could be that, while a lobbyist may be connected to a politician, it is really the client hiring the lobbyist that is paying the campaign contributions to the politician, and not the lobbyist directly. This alternative concern may be partially addressed by considering the relationship between the campaign contributions received by politicians from lobbyists and from their clients respectively. While it is particularly cumbersome to explore any possible client-lobbyist-congressman connection in the data, the Center for Responsive Politics (CRP) presents lobbyist-client clusters of donations to members of Congress between January

\footnotetext{
${ }^{21}$ FEC disclosure requires indicating the individual name, occupation and employer of the donor, allowing a precise match to SOPR data.

${ }^{22}$ Lipton (2010) [A GOP Leader Tightly Bound to Lobbyists, 09/11/2010, New York Times].

${ }^{23}$ On second thought, this might be intuitive. While it is reasonable to assume that politicians certainly allow communication without payment from closely connected lobbyists, the strong ties are also the first to be pulled when politicians need funds.
} 
2007 and June $2009 .{ }^{24}$ Clients must be members of the health care/health insurance industry and have hired at least ten outside lobbyists who display some campaign contribution to the same Congressmen as the clients contributed to. Under the view requiring clients to carry the bulk of the campaign donations relative to their lobbyists, the amount of campaign contributions received by congressmen from clients should vastly exceed the lobbyists' donations. Quite the contrary, for 52 out of 61 congressmen identified by the CRP as recipients of lobbyist-client bundles the amount of lobbyists' contributions exceeds what paid by clients. The lobbyist-client difference is large and statistically significant with lobbyists contributing on average $\$ 14,642$ more than their clients, an average relative difference of about $+50.4 \%$.

Table 4 reports means and trends for the campaign contributions measures. The unit of observation is a given lobbyist in an active year and all observations are equally weighted when computing the statistics. Across all lobbyist-year observations (Panel A), the fraction of lobbyists with at least one donation is 27 percent; about 8 percent make contributions to more than 5 politicians in the average year they are active as lobbyists. The trends analysis reveals an upward swing in both the frequency and number of donations, with maybe a bit of a slowdown in the last sample year. When we focus on lobbyists with staying power (those active in lobbying for at least 4 years between 1999 and 2008 - Panel B), the pattern of increased connectivity over time between lobbyists and politicians becomes even clearer: for example, while only about 9 percent of lobbyists active in 1999 are of the type that makes campaign contributions to 5 politicians or more in a given Congress, that fraction goes up to 13 percent by 2007/2008.

A comparison of panels C and D reveals a large difference between in-house and external lobbyists. Connections through campaign contributions are much more common among external lobbyists than among those that work in-house. For example, while we categorize about 14 percent of external lobbyists as with "many connections", 3 percent of in-house ones fall into this category. Figure 1B displays the distribution of the share of lobbyists with "many connections" across lobbying entities for the entire sample period. As for Figure 1A, our motivation for looking at such distribution is the possibility that a subset of lobbying firms might want to

\footnotetext{
${ }^{24}$ http://www.opensecrets.org/lobby/lm_health.php
} 
differentiate by "specializing in connections." Under this view, one might expect multiple modes when plotting the distribution of the share of very connected lobbyists across firms. As for Figure 1A, we compute the share of very connected lobbyists in a firm by weighing each lobbyist-firm observation by the number of records he or she was listed on across the entire sample period and we restrict ourselves to the sample of organizations that employ at least two lobbyists over the entire sample period. The distribution of the share of connected lobbyists appears to be very spread out among professional lobbying firms. There is a large mode around 0, but also two smaller modes around .5 and 1 .

\section{Background Determinants of Expertise and Connections}

Table 5 relates specialization to lobbyist's biographical information. ${ }^{25}$ The unit of observation is a lobbyist and all lobbyists are equally weighted in these OLS regressions. We present regressions both for all lobbyists (odd columns) and for those with at least 4 years of presence in the SOPR data (even columns). The dependent variable in the first 6 columns is the "specialist" dummy; the dependent variable in the last 6 columns is the issue-based HHI. The main theme that emerges from this Table is that lobbyists with prior political experience or political affiliations are less likely to be experts. For example (column 2), lobbyists with prior association with the Republican or Democratic party are about 5 percentage points less likely to be specialists; former members of Congress are about another 3 percentage points less likely to be specialist (not statistically significant); those lobbyists with experience in some White House offices are another 5 percentage points less likely to be specialist. There is also some evidence (especially apparent with the more continuous HHI measure in Panel B) that expertise tends to be a more common asset for older lobbyists (e.g. those whose biographies go back to the 1960s and 1970s). The patterns above appear to be more systematic and more precisely estimated among external lobbyists.

In summary, the regressions in Table 5 appear to contradict the view that expertise on specific technical issues is the main asset being transferred through the revolving door between Capitol

${ }^{25}$ The sample here is of course smaller, e.g. limited to the subset of lobbyist we could identify in www.lobbyist.info and for whom detailed biographical data was available. 
Hill or offices in the executive branch and the lobbying world. Of course, it could be other forms of expertise that this selected group of lobbyists is bringing to the table, such as some general knowledge of the law-making process. Our results do however contradict the view that revolving door lobbyists bring specific knowledge of complex topics such as, say, health care policy or the economics of financial markets.

Following the same format as Table 5, Table 6 relates lobbyists' contacts to politicians to their biographical information. Again, the unit of observation in this Table is a lobbyist and all lobbyists are equally weighted. There is unambiguous evidence that past experience on the Hill or in the White House is associated with more connections to politicians through campaign contributions. Consider the last 6 columns, where the dependent variable is a dummy variable that equals 1 if the lobbyist makes campaign contributions to at least 5 politicians in the average Congress we observe him in the lobbying records. We find (column 7) that lobbyists with associations with the Republican or Democratic parties are respectively 10 and 14 percentage points more likely to fall in this "many connections" category. Former members of Congress and those with some prior experience around the White House are respectively another 14 and 10 percentage points more likely to maintain many connections to politicians.

Table 7 provides some evidence on which lobbyists make campaign contributions to which politician. We perform this analysis separately by Congress and present results for the $107^{\text {th }}$ and $108^{\text {th }}$ Congresses. Within each Congress, we restrict ourselves to the subset of lobbyists for whom we could find background information on www.lobbyist.info and are active during that term and to the subset of politicians that are Members of Congress during that term. We then create all possible lobbyist-lawmaker pairs (by cross-matching the list of lobbyists with the list of Congressmen and women) and create a dummy variable that equals 1 if the lobbyist in a pair has made a campaign contribution to the lawmaker in that pair, 0 otherwise. We perform the analysis both with and without lobbyist and lawmaker fixed effects. Standard errors are clustered at the lobbyist level. Maybe not surprisingly, whether a given lobbyist contributes to a given politician's campaign is systematically related to whether the lobbyist and the politician share the same political ideology. 


\section{Are Connections to Politicians Related to What Lobbyists Do?}

The empirical approach we have followed so far to measure how connected a given lobbyist is has consisted in counting the number of politicians the lobbyist makes campaign contributions to. However, there is nothing in the way we constructed this measure that systematically establishes a link between these campaign contributions and the lobbyists' main professional activities. Lobbyists, like any other individuals, may decide to express their personal support for a political candidate by giving to their political campaign. Such personal taste would be consistent with our findings in Table 7 where lobbyists' campaign donations follow ideological lines. Yet, in this section, we show that there is more to the campaign contributions than just a private showing of political support. Whom lobbyists give to (and most likely whom lobbyists know) is systematically related to what issues they work on. In fact, we will show later in this section evidence for a much stronger result: lobbyists appear to change issues in a predictable way as the legislators they are connected to (through campaign contributions made in the past) change committee assignments.

The nature of the empirical exercise we perform in Table 8 is as follows. As in Table 7, we perform our analysis separately by Congress and present for now results for the $107^{\text {th }}$ and $108^{\text {th }}$ Congress. (We obtained qualitatively similar results for the other sessions of Congress covered in our sample time period). We start with the pool of all Senators and House Representatives in a given Congress. We then use committee assignment information to determine the specific lobbying issues ${ }^{26}$ each of these Members of Congress are particularly tied to in that Congress. ${ }^{27}$ For instance, the powerful House Appropriations committee maps into the lobbying Budget issue (BUD). As we did for Table 7, we then create a dataset that includes all possible lobbyistlegislator pairs in a given Congress by crossing the pool of active lobbyists with the pool of lawmakers.

\footnotetext{
${ }^{26}$ For the full list see SOPR instructions for Lobbying Disclosure files (line 11) available at http://www.senate.gov/reference/resources/pdf/LD1_Instructions.pdf

${ }^{27}$ Appendix A3 reports the correspondence matrix between House and Senate committees and lobbying issues. The data on committee assignments is from Stewart and Woon (2009).
} 
For each lobbyist-legislator pair, it is possible to construct some measures of the "issue overlap" between the legislator and the lobbyist in the pair. The first measure we propose simply counts the number of issues a given legislator is assigned to (given his or her committee position in that Congress), that also appear in at least one of the lobbying records associated with the lobbyist during that session of Congress. We also define a dummy variable that equals 1 for a lobbyistlegislator pair if the lobbyist's records during that session of Congress cover all the issues assigned to the legislator in that Congress, 0 otherwise.

In this sample of all possible lobbyist-legislator pairs in a given Congress, we then test whether the issue overlap between the lobbyist and legislator in the pair is systematically larger when the pair actually exists in the campaign contribution data, e.g. when the lobbyist made a campaign contribution to that legislator in any of the two years that Congress was in session.

The first four columns of Table 8 focus on the $108^{\text {th }}$ Congress, the last four on the $107^{\text {th }}$ Congress. Reported in each column is the estimated coefficient on a dummy variable that equals 1 if the lobbyist made a campaign contribution to the legislator, 0 otherwise. Note that for each overlap measure and Congress we report the results of two regressions: one with legislator fixed effects and one with lobbyist fixed effects; such fixed effects are important since, for example, the overlap measures we have defined may largely vary across legislators simply based on whether they are assigned to narrowly-focused committees or committees with broader mandates. Also, standard errors are clustered at the lobbyist level.

There is systematic evidence across all Congresses that the existence of a campaign contribution connection between a lobbyist and a legislator is associated with a higher likelihood that the lobbyist and legislator work on the same issues. For example, the likelihood of a perfect issue overlap between a lobbyist and a legislator (e.g. the lobbying records associated with that lobbyist during that session of Congress cover all the issues associated with the legislator's committee) in a random pair in the $108^{\text {th }}$ Congress is 11.5 percent. The likelihood increases by 2.9 percentage points, or about 25 percent if the lobbyist made a campaign contribution to that legislator (column 3, Table 8), controlling for whether the lobbyist and legislator share political orientation or house or senate affiliations. 
The evidence put forward in Table 8 suggests that campaign contributions are not simply a reflection of the lobbyists' personal political tastes; instead, lobbyists' campaign contributions are systematically related to the lobbyists’ professional engagements.

Before exploring different mechanisms that might explain this evidence, we take a first step towards understanding better how connections between lobbyists and politicians relate to their respective work assignments by replicating the analysis from Table 8 on various relevant subsamples of the data. Again, we report results only for the $107^{\text {th }}$ and $108^{\text {th }}$ Congress but have obtained qualitatively similar results for other time periods. A few consistent patterns emerge from the heterogeneity analysis presented in Table 9. First, it appears that the correlation between issue overlap and campaign contributions is limited to the set of external lobbyists. For in-house lobbyists, we do not seem able to predict what issues they work on based on whom they make campaign contributions to. This is obviously likely related to the fact that campaign contributions by in-house lobbyists are a much rarer occurrence (Table 5). ${ }^{28}$ Interestingly, the association between campaign contributions and issue overlap is quantitatively stronger among expert lobbyists than among non-experts, even though a statistically significant association exists for both groups.

The statistical associations we have isolated in Tables 8 and 9 imply a relationship between whom lobbyists know and what they work on. There are however many different ways to interpret such a relationship. We are particularly interested in separating two possible interpretations. The first interpretation is that what determines what a lobbyist works on is whom he or she knows: because a lobbyist knows a given politician (as proxied for by making contributions to that politician's campaign), he or she has influence on that politician and therefore is particularly effective in affecting outcomes related to the issues this politician's committee covers. In a sense, under this first interpretation, whom a lobbyist knows comes first and this determines in great part what he or she works on. A second interpretation is that what a

\footnotetext{
${ }^{28}$ It is possible though that, for in-house lobbyists, we are missing a big part of the connections to politicians as those may occur through campaign contributions directly made by the firms and organizations that employ those lobbyists, rather than by the lobbyists themselves.
} 
lobbyist knows determines which politician he or she is more likely to establish some connections with. Under this second interpretation, lobbyists are defined by what they know more than whom they know. However, there is some friction in the communication of this expertise, maybe because of lawmakers' overburdened schedule and limited attention span. Campaign contributions are then a way to get politicians' attention; they serve as some grease in the transmission of information and expertise between lobbyists and lawmakers. In Tables 10 and 11, we present a concrete attempt at parceling out these two mechanisms.

In Tables 10A, B and C, we present an empirical test of whether lobbyists "stick to" the people they know when it comes to what issues they work on. If lobbyists essentially provide companies with access to politicians in their "circle of influence," one would expect lobbyists' job assignments to be determined by the identity of the politicians in charge, independent of the specific issues being decided upon; hence a lobbyist should "follow" a congressman that he or she knows as the congressman moves from one committee assignment to another.

To perform that test, we isolate the subset of Congressmen that switch committee assignments between Congress $t$ and Congress $t+1$. Such switches can be safely assumed exogenous to the lobbyist's decision, as mostly driven by congressmen's tenure and idiosyncratic electoral shocks to members of the committee. We form all the possible pairs between a given Congressman and the lobbyists in our sample and create issue overlap in the pair at $t$ as previously defined (the number of issues that the politician works on at time $t$ that are covered by the lobbyist at time $t$ ). Because of computational constraints we cannot consider all the lobbyists in the sample, so we adopt the strategy of keeping only those that work on similar issues as the politician before the reassignment. For this group it is easier to establish whether the lobbyist follows the Congressman given a common point of “departure”. We therefore keep the 1000 lobbyists (and therefore pairs) that are closest to the Congressman in terms of issue overlap at time $t$. The data set is formed by appending 1000 pairs for each "switcher" for each Congress. Notice that there are 513 Congressman that switch assignment at some point in the period considered, so we have 513,000 pairs. For each pair we create a connection dummy variable that is one if the lobbyist and the Congressman are actually connected through campaign contributions. 
We then ask in Table 10A whether the overlap of issues covered by the lobbyist and the Congressman in $t+1$ can be predicted by whether the pair was connected in Congress $t$. The dependent variable is the number of new issues ${ }^{29}$ that both lobbyist and politician work on at time $t+1$. As a control, the overlap between the lobbyist in Congress $t$ and Congressman in Congress $t+1$ captures the fact that the lobbyist may be already working on the issues the legislator takes up as new assignment.

In all columns of Table 10A we find evidence that lobbyists follow the lawmakers that they have connections with, as those lawmakers switch committee assignments. Specifically, we find a larger overlap in Congress $t+1$ when the lobbyist had previously made campaign contributions to the politician in the pair. Starting from column 1 where we only include Congress fixed effects, the results are qualitatively unchanged if we add Congressman fixed effects (column 2), controls for the lobbyist characteristics (column 3), lobbyist fixed effects (columns 6 to 8), issue overlap at $t$, or if we limit our analysis to the lobbyist.info sample (columns 4 and 5). In columns 6 to 8 , the analysis based on within lobbyist variation confirms that, given a lobbyist, he is more likely to follow a politician when he is connected to him. At a mean 1.3 overlap of new issues at $t+1$ the estimated effect ranges between about 8 and 28 percent additional overlap for connected lobbyists.

In Table 10B we look at possible heterogeneity of this finding across relevant subsamples of lobbyists and lawmakers. First, we see that the relationship we have uncovered only applies to external lobbyists. Moreover, the relationship between prior connections and future work assignments seem to exist only for non-specialists.

In Table 10C we repeat the analysis in the sample of freshmen, i.e. Congressmen that enter Congress at $t+1$. Notice that we still observe contributions during the campaign stage and therefore all variables of interest, except for issue overlap at $t$, can be defined for this sample. Since we are including all lobbyists, table 10C performs the analysis separately for sets of Congresses, for computational reasons. The results are largely confirmed: as freshmen are

\footnotetext{
${ }^{29}$ New from the Congressman point of view, i.e. the set of issues that the Congressman works on at time $t+1$
} 
elected and are assigned to given committees, lobbyists who gave them campaign contributions start working on the same issues (controlling for whether the lobbyist was already working on those issues).

An alternative and simple, although indirect, way of quantifying the degree to which lobbyists enter new issues as politicians switch to new committee assignments is to relate the amount of churning for these two groups. More specifically, for each issue and congress we calculate the fraction of new congressmen assigned to the issue and the share of dollars spent on the issue coming from lobbyists that did not work on the issue in the prior congress. When weighting by dollar amount attached to the issues, the correlation between the two "entry" variables is $40 \%$. This implies that, if all congressmen were new to an issue, then $40 \%$ of lobbyists in dollars terms would be new to the issue. This figure is $80 \%$ if we limit the analysis to those issue-congress observations that are above the median in terms of the share of Congressmen that have at least one connection to lobbyists.

Table 11 provides evidence that connections to politicians are also endogenously created by lobbyists as new lawmakers enter their area of expertise. We again restrict the sample to the subset of lawmakers that switch committee assignments between two consecutive sessions of Congress. We form all pairs of these politicians with every lobbyist in Congress $t+1$ and for computational reasons we analyze only two Congresses $\left(107^{\text {th }}\right.$ and $\left.108^{\text {th }}\right)$. The dependent variable is now a dummy that equals 1 if the lobbyist made at least one campaign contribution to the lawmaker in the pair in Congress $t+1$. The independent variable of interest is a measure of issue overlap between the lobbyist at $t$ and the Congressman at time $t+1$. More specifically we define a 'lead' issue overlap as the number of issues covered by Congressman at time $t+1$ that are covered by the lobbyist at time $t$. The question we ask is whether, as the 'lead' issue overlap increases, i.e. a politician moves at $t+1$ into issues coinciding with those already covered by the lobbyist at time $t$, the lobbyist is more likely to establish a connection with that politician. We control for whether a connection was already established at time $t$ and for issue overlap at time $t$. We find a significant effect of lead issue overlap on connection at time $t$. The coefficients in the full sample range are positive and statistically significant, implying a higher propensity to contribute to congressmen entering the area of activity of the lobbyist. The coefficient estimates 
range between 0.00069 and 0.00059 (Table 11 reports coefficients in x1000 units), so that a one unit increase in lead issue overlap increases the probability of a connection being established by $29.5 \%$ to $34.5 \%$ relative to the average probability of a connection $(0.2 \%)$. The heterogeneity analysis in the remaining columns of Table 11 suggests again that the relationship we observe mostly extends to the pool of external lobbyists.

The evidence in Tables 10 and 11 suggests that there are two broad types of connections. Some connections are long-standing and come first in determining what a lobbyist works on. Other connections are created as politicians enter the area of activity of a lobbyist.

\section{What Makes a Lobbyist Valuable?}

\section{A. Report-level Analysis}

Our analysis so far suggests that lobbyists' personal access to lawmakers, as proxyied for by the campaign contributions they make to these lawmakers, might be a consequential driver of what issues they work on. A complementary approach to assess the relative importance of access versus issue expertise in the lobbying process might consist in asking how much these two assets are valued. Who is paid more? Is it a lobbyist with lots of connections to politicians, or a lobbyist that masters the intricate details of health care policy or financial market reforms? Unfortunately, we do not have any information on lobbyists' income. ${ }^{30}$ But we do observe the price tag associated with each lobbying report. It is therefore possible to assess how the characteristics of the lobbyists that are assigned to a report relate to how much was spent on that report. We perform this analysis in Table 13. Because of computational constraints and because the previous

\footnotetext{
${ }^{30}$ Concerning payment structures: "There are several fee structures on K Street, from annual retainers and lump sums for specific projects to monthly and even hourly rates. [...]. Some firms with stellar reputations for gaining access to high levels of government charge annual fees and usually take on whatever lobby efforts, large or small, are required during the term of the contract. Sometimes, when things are heating up in Washington, clients will often drop big money to make sure that their Washington representatives have the pedal to the floor until the race is run. But it is most common to find clients paying a monthly rate. Universities, local and municipal governments, and companies that are most closely focused on the appropriations process pay fees of between $\$ 5,000$ and $\$ 30,000$ a month. [...] Several lobbyists say prices are negotiable, depending on the length of the lobbying relationship, the intensity of the work, and the client's perceived ability to pay [...]."' [LobbySearch: The Who, When, and How Much of Hiring a Lobbyist].
} 
patterns we have documented are much more pronounced for external lobbyists we limit our analysis to this group. An obvious limitation of this empirical approach is that we cannot isolate the contribution of an individual lobbyist to a given report (recall that most report have more than one lobbyist assigned to it). In Table 14, we will present an alternative approach where we try to get at individual lobbyists' value-added to a given report by estimating a vector of lobbyist fixed effects.

Before discussing the record-level analysis in Table 13, we report in Table 12 the total dollar decomposition of lobbying aggregate amounts by category of lobbyists. Connected lobbyists and lobbyists with multiple connections not only command a very large share of the industry in terms of aggregate revenues, but also stand out in terms of amounts per lobbyists (connected lobbyists cover 42 percent of the revenues but are only 25 percent of the industry population). Specialists command substantially lower shares, even if they represent 25 percent of the population. For external lobbyists the patterns are even more pronounced.

The disproportionate returns accruing to lobbyists with connections in this simple decomposition is a recurring theme in the remainder of this section. We have documented the existence of two types of connections through campaign donations. One conforms to the standard "pay to play" view of campaign contributions: a link is temporarily established by a lobbyist to access the relevant politician (Sabato, 1985). The other stands in for deeper and hard-to-replicate ties. However, only the latter can command a premium in excess of what is necessary to pay for access, i.e. individual campaign donations (currently capped at $\$ 2,400$ by the FEC). The high returns to connectedness estimated below largely exceed such amount, lending support to the hypothesis that a significant fraction of the observed connections stand in for deeper and longstanding relationships.

The prominence of premia to connections over expertise is evident in the report-level analysis of Table 13. The unit of analysis is an external lobbying record, as defined in the SOPR data. The dependent variable is the logarithm of the dollar amount attached to that report, $\ln \left(V_{r t}\right)$. All regressions reported in Table 13 include a vector of year dummies, a vector of dummies for report type (e.g. end-of-year report or mid-year report), and a vector of dummy variables for the 
issues that are being covered in the report. We also control non-parametrically for the number of lobbyists included on the report (with separate indicator variables for all numbers -from 1 to 62). Finally, all regressions include controls for the average tenure of the lobbyists assigned to the report, as well as the average number of active years among these lobbyists over the entire sample period and the average number of reports per lobbyist on the team per year. For ease of interpretation we construct two dummy variables. The first one equals 1 if there is at least one specialist in one of the issues covered by the report. The second dummy equals 1 if there is at least a lobbyist on the report that is connected to a politician that works on an issue in that report.

We find qualitatively similar results across all specifications. Specifically, everything else equal, we find a premium of about 3 to 5 percent for a lobbying report that has a relevant specialist, while that premium is about 8 to 10 percent for a report with a relevant connected lobbyist. Overall, having a specialist on the team comes at a premium, but having connected lobbyists commands a premium twice as large. Given an average report amount $V_{r t}$ of $\$ 63,200$, this implies a per-report premium of $\$ 5,056-\$ 6,320$ per connected lobbyist ${ }^{31}$.

The last column of Table 13 introduces a number of characteristics of the lobbyists on the report. We find additional premia for most of the variables that describe the political background of the lobbyists on the team. Everything else equal, staffing a lobbying case exclusively with former Members of Congress increases its price by about 12 percent. Teams composed of lobbyists with Democratic and especially Republican affiliations cost more. The largest premium we observe is for lobbyists with past experience in the White House.

\section{B. Lobbyist-Level Analysis}

The report-level analysis above suggests interesting patterns that can be further investigated moving to an individual lobbyist analysis. As indicated above, one of the difficulties with the report-level analysis is that we cannot zero in on the value added of a specific lobbyist. Hence,

\footnotetext{
${ }^{31}$ The premium is computed per report and thus needs to be further multiplied by the number of reports on which a lobbyist typically works on (between 23 and 45 per year on average and assuming that a connected lobbyist works on reports where he is connected to a politician that works on an issue in that report) to obtain a yearly connection premium. This places the value of a connection in excess of $\$ 116,000$ per year.
} 
we can only estimate premia at the working team level. For a subset of lobbyists that can be observed working with diverse set of co-workers, though, it is possible to estimate fixed effects in the dollar amount associated with having their name attached to a lobbying report.

Specifically, we start with a dataset where the unit of observation is at lobbyist*lobbying report level. We define as the dependent variable the logarithm of the total dollar amount associated with that lobbying report $\ln \left(V_{r t}\right)$ (the same dependent variable as in Table 13, $\ln \left(V_{r t}\right)$ is now replicated for each lobbyist in the report). We then estimate lobbyist fixed effects in a regression that also includes year dummies, a vector of indicator variable for all issues or topics, and nonparametric controls for the number of lobbyists associated with the report $L_{r t}$ (e.g. dummies for each possible size of the lobbying team).

Intuitively, it should be clear that such lobbyist fixed effects cannot be estimated for all individuals. To fix ideas, consider a pair of lobbyists that always work together. It will be impossible to separately estimate separate fixed effects for each of them. Instead, we will only be able to compute fixed effects for those lobbyists that we observe as part of changing teams across lobbying reports. Because the estimation of such individual fixed effects (and the standard errors associated with them) is quite computationally intensive, we for now restrict the sample to external lobbyists that are active in at least 6 years over the entire sample period. Furthermore, this condition guarantees lower measurement error in the fixed effect estimates. ${ }^{32}$

Once we have computed the lobbyist's fixed effects, we can then relate them to each lobbyist's level of expertise, connections and past professional experience. We do this in Table 14, where the unit of observation is a lobbyist and the dependent variable is the estimated lobbyist fixed effect derived from the regression outlined above. We estimate median regressions, which allow us to better address outlier concerns; we also weigh each observation by the inverse of the standard error associated with the estimated fixed effect for that lobbyist/observation further accounting for noise in the estimation.

\footnotetext{
${ }^{32}$ For estimating each fixed effect at least six observations are available. For a related discussion Besley and Preston (2007) who discuss the issue of consistency of the individual-specific fixed effects in the case of assessing bias of local authorities with small $T$.
} 
Before moving to the regression results, we discuss Figures 2 and 3, which graphically show how the distribution of lobbyist fixed effects relate to both their expertise and their level of connections. In Figure 2, we see that the distribution of fixed effects for specialists and nonspecialists are almost identical. When we separate lobbyists into those with high (>.33) and low issue-based HHI, we find the distribution of fixed effects for the high HHI group to be more spread out and with more mass towards low fixed effects compared to the distribution of fixed effects for the low HHI group. Hence we observe no premium associated with issue expertise. If anything, those lobbyists that concentrate on fewer issues appear to come at a discount. Figure 3 plots the distributions of lobbyist fixed effects for those with no political connection and those with at least one connection (top), as well as for those with 5 connections or more in any given Congress and those with less than 5 connections (bottom). In both cases, it is very clear that the distribution of fixed effects for those with some or many connections is shifted to the right compared to the distribution for those with no or few connections.

The regression analysis in Table 14 qualitatively confirms the patterns we observed in Figures 3 and 4. Issue experts do not receive any premium; if anything, a higher level of issue concentration carries a discount. ${ }^{33}$

In contrast, there is a positive and significant premium associated with having more political connections through campaign contributions. The premium appears to be especially large for those lobbyists that entertain many connections to politicians (6 to 10 percent). Even after controlling for connections, we still find a large premium associated with some of the political background characteristics. In particular, everything else equal, past experience in the White House increases a lobbyist fixed effect by 12 to 15 percent. The premium associated with affiliation to the Republican party is larger and more precisely estimated than the premium associated with the Democratic party. The estimated coefficient for former Member of Congress

\footnotetext{
${ }^{33}$ This evidence can be reconciled with the report-level results: the fixed effect analysis provides a measure of the average return to a specialist, which is revealed to be lower than for non-specialists. This is not in contrast with the fact that when they work on issues on which they are experts, specialists may receive a higher than average compensation.
} 
is quantitatively smaller ( 2 to 8 percent) and less precisely estimated here than in the report-level analysis in Table $13 .^{34}$

\section{C. Issue Cycles and Political Cycles}

In this section we perform alternative exercises aimed at measuring whether premia associated to issue expertise or to connections change with, respectively, the 'issue cycle' and the 'political cycle'. More specifically in our first exercise we ask whether a lobbyist that has affiliation to a specific party sees his average return increase as this party moves to a position of power.

Figure 4 presents evidence that connections to politicians matter for lobbyists' professional activities and particularly for their average revenue. In computing those measures, we assign to each lobbyist on the report the average per lobbyist dollar amount on that report $V_{r l t}$, aggregate over each year and take logs. Figure 4 reports the Republican lobbyist revenue premium in percentage terms relative to a Democratic lobbyist (benchmarked at zero) based on total perlobbyist per-year amount reported in the SOPR data. Republican lobbyists tally higher revenues during Republican Congresses and Republican administrations (up to 30\% more during the first year of Bush's second term). ${ }^{35}$ The political cycle is not driven by specific issues being more likely to be associated to certain parties. Revenue premia are virtually unchanged running the specification issue-by-issue in the vast majority of issues. This estimated revenue cycle can be attributed to a decrease in the value of connections when political allies are out of office. In this sense this result is very much in line with the finding of Blanes-i-Vidal, Draca, and Fons-Rosen (2010) that assess a 20\% drop in revenues occurring to lobbyists with past experience as senatorial aides when their connected Senator leaves office.

\footnotetext{
${ }^{34}$ In regressions not reported here, we also tested for the possibility that expertise might only be valuable when combined with connections, a possibility that seemed in keeping with some of the patterns we observed in Table 9 . We tested for this hypothesis in both the report-level analysis and the lobbyist fixed effect analysis. We did not find this interaction term to be economically or statistically significant.

${ }^{35}$ The picture also clearly emphasizes the success of the so-called K-Street Project implemented by the Republican party leadership during the first part of the 2000's. The project was a "database intended to track party affiliation, hill experience and political giving of every lobbyist in town.” [Confessore (2003), Welcome to the Machine, 03/07/2003, Washington Monthly] with the explicit aim of selectively assigning political access to GOP lobbyists.
} 
In Appendix Table A2, we also report, by year, total lobbying expenses associated with lobbyists with a Republican affiliation and total expenses associated with lobbyists with a Democratic affiliation. We also report, by year, number of active lobbyists with Republican or Democratic affiliations. The patterns in this data match political cycles. In particular, the RepublicanDemocratic gaps (columns 3 and 6) appear smallest in the very first years of the sample (Democratic President) and the last few years (Democratic Congress). Hence, Republican (Democratic) lobbyists seem to be professionally more active when political power in Washington moves to the right (left).

In our second exercise we ask whether the average return to an issue-specialist increases in periods where that issue becomes more popular and spending on that issue increases overall (perhaps because a relevant piece of legislation is being discussed in Congress or at the committee level). We construct our measure of issue cycle as follows. Consider the value $V_{r t}$ of report $r$ at time $t$, and divide it by the number of issues on that report $I_{r t}$. This generates an average value per issue $i$ on report $r, V_{i r t}$. Then we sum across all the reports that contain issue $i$ at time $t, R_{i t}$ to obtain $V_{i t}$, the total amount spent on issue $i$ at time $t$ :

$$
V_{i t}=\sum_{r=1}^{R_{i t}} V_{i r t}
$$

For each lobbyist $l$ we construct a variable that captures whether the issue in which the lobbyist is an expert is booming. Define the set of issues for which lobbyist $l$ is a specialist as $S_{l}$ and then construct a lobbyist-specific issue cycle measure $C_{l t}$ :

$$
C_{l t}=\sum_{i=1}^{s_{l}} V_{i t}
$$

In Table 15B the dependent variable is the average return for lobbyist $l$ at time $t, V_{l t}$ (previously defined). The results show that the average return to a lobbyist does not seem to respond to an expansion, in dollar terms, of the issues in which a lobbyist is specialized. In Table 15A we show that the adjustment during a boom is mainly in terms of non-specialists entering a given issue. 
More specifically the first panel shows that the total number of lobbyists working on a given issue increases when the issue expands, while the second panel shows that the share of issuespecialists declines during an issue boom, hinting to the fact that entry is primarily by nonexperts. This seems to point to relatively low barriers to entry in a specific issue.

In summary, assuming one takes the analysis in Tables 12,13,14, and 15B as evidence of what lobbyists' characteristics are most prized, we find weak support to the view that issue expertise is what makes a lobbyist "special." Instead, the lobbyists that appear to earn a premium are those that have connections to many politicians and to the ruling political party. At first glance, the barriers to entry in establishing connections to politicians of the type we track here appear quite low (the average donation to a campaign is just a few thousand dollars). Such low barriers to entry seem inconsistent with the view that "connected" lobbyists would maintain a sustainable comparative advantage of the magnitude we measure here. What is likely going on is that the campaign contributions are a symptom of deeper connections between lobbyists and politicians, which cannot as easily be replicated by others. In contrast, it appears that the barriers to entry into issue expertise are either indeed quite low (maybe the experts do not need to be the lobbyists themselves but can be brought in from industry or academia) or that issue expertise is really not necessarily instrumental to "winning” a lobbying case.

\section{Conclusions}

Our objective in this paper is to provide some guidance on what lobbyists actually do. We were motivated by two opposite views of lobbying that have been discussed both in the policy and media circles and in the academic literature ${ }^{36}$. The first view considers lobbyists as issue experts who can contribute valuable information to the law- and rule-making process; the second view considers them more as sources of access to lawmakers, because of their personal ties and knowledge of those lawmakers. The lively debate surrounding what lobbyists actually do has been made particularly relevant by the dramatic growth of the lobbying industry over the last decade and their recent prominence as actors in the policy debate during the 2008-09 crisis.

\footnotetext{
${ }^{36}$ Heinz et al. (1993); Salisbury et al. (1989).
} 
There are also some direct policy implications to this debate when it comes to recent proposals and attempts to totally or partially shut the revolving door between jobs on the Hill (or in other top government offices) and jobs in lobbying. On the one hand, revolving door lobbyists might be those that have the most issue expertise due to their prior experience; on the other hand, revolving door lobbyists might be those with the most personal contacts and the most influence on lawmakers.

This paper combines some purely descriptive analysis with some more ambitious attempts to get inside the black box of the lobbying process. The main takeaway from our analysis is that a pure issue expertise view of lobbying does not fit the data well. Instead, maintaining connections to politicians appears central to what lobbyists do. Such connections however need not necessarily raise a flag about unethical or illegal practices. We do see evidence of lobbyists' prior knowledge and expertise driving whom they decide to connect to, maybe a sign that connections are needed for efficient communication between informed lobbyists and time- and attention-constrained lawmakers. But we do also see evidence of lobbyists' job assignments being driven by whom they know rather what they know. This finding is mirrored in the returns to connections being larger than returns to expertise.

One might wonder whether, even if our results do not support an expertise view of what lobbyists do, the evidence is compatible with a scenario in which lobbyists, not experts themselves, report to politicians the information produced by expert researchers working for the lobbying firm. Such view of lobbyists as mere "messengers" is, we believe, incompatible with the large fees assessed for their services. The price tag attached to lobbyists services suggest that they bring to the table a complementary resource, perhaps reputation, credibility or political savvy, in the transmission of information. ${ }^{37}$ We believe the mechanism by which information and reputation combine in creating value in the services of lobbyist is intriguing and deserves attention in future theoretical research.

\footnotetext{
${ }^{37}$ Birnbaum (2005): "Starting salaries have risen to about $\$ 300,000$ a year for the best-connected aides eager to 'move downtown' [to K street in 2005] from Capitol Hill or the Bush Administration." [The Road to Riches Is Called K Street, 6/22/2005, The Washington Post]
} 


\section{References}

Ainsworth, Scott (1993) "Regulating Lobbyists and Interest Group Influence” Journal of Politics, Vol. 55(1), pp. 41-56.

Apollonio, Dorie, Bruce E. Cain and Lee Drutman (2008). “Access and Lobbying: Looking Beyond the Corruption Paradigm”. Hastings Constitutional Law Quarterly, Volume 36, issue 1.

Ansolabehere, S., J. Snyder, and M. Tripathi (2003). "Are PAC contributions and lobbying linked? New Evidence from the 1995 Lobby Disclosure Act”. Business and Politics 4(2):131155.

Austen-Smith, David (1987). "Interest Groups, Campaign Contributions and Probabilistic Voting." Public Choice 54(2): 123-39

Austen-Smith, David (1993). "Information and Influence: Lobbying for Agendas and Votes." American Journal of Political Science 37:799-833.

Austen-Smith, David (1994). “Strategic Transmission of Costly Information”, Econometrica 62, pp. 955-963.

Austen-Smith, David (1995). "Campaign Contributions and Access." American Political Science Review 89:566-81.

Austen-Smith, David, and J.S. Banks (2002). "Costly signaling and cheap talk in models of political influence”, European Journal of Political Economy 18: pp. 263-280.

Austen-Smith, David and John R. Wright (1994). "Counteractive Lobbying." American Journal of Political Science 38(1): pp. 25-44.

Austen-Smith, David and John R. Wright (1996). "Theory and Evidence for Counteractive Lobbying." American Journal of Political Science 40(2): pp. 543-564.

Baron David P. (1989) "Service-induced campaign contributions and the electoral equilibrium", Quarterly Journal of Economics 104(1), pp. 45-73

Baron, David P. (1994). "Electoral competition with informed and uninformed voters", American Political Science Review 88(1), pp. 33-47.

Baumgartner, F.R. and B. Leech (2001) " Interest Niches and Policy Bandwagons: Patterns of Interest Group Involvement in National Politics" Journal of Politics 63 (4), pp. 1191-1213.

Bennedsen, M. and S.E. Feldmann, Lobbying legislatures, Journal of Political Economy 110 (2002) (4), pp. 919-948. 
Besley, Tim, and Steve Coate (2001) "Lobbying and welfare in a representative democracy", Review of Economic Studies 68, pp. 67-82.

Besley, Tim, and Ian Preston (2007) "Electoral Bias and Policy Choice: Theory and Evidence” Quarterly Journal of Economics, 122(4), pp. 1473-1510.

Blanes-i-Vidal, Jordi, Mirko Draca, Christian Fons-Rosen (2010) "Revolving Door Lobbyists", mimeo LSE.

Bombardini, M. (2008). "Firm Heterogeneity and Lobby Participation." Journal of International Economics, 75 (2), pp.329-348

Bombardini, M. and F. Trebbi (2009) "Votes or Money? Theory and Evidence from the US Congress" mimeo University of British Columbia.

Bombardini, M. and F. Trebbi (2008) " Competition and Political Organization: Together or Alone in Lobbying for Trade Policy?" mimeo University of British Columbia.

Calvert, R.L. (1985) "The value of biased information: a rational choice model of political advice", Journal of Politics 47, pp. 530-555.

Crawford,V., and J. Sobel, "Strategic Information Transmission", Econometrica 50, pp. 14311451.

Dixit, A., G.M. Grossman and E. Helpman (1996) "Common agency and coordination: general theory and application to government policy making”, Journal of Political Economy 105 (4), pp. 752-769.

Drutman, Lee J. (2010) "The Business of America is Lobbying: The Expansion of Corporate Political Activity and the Future of American Pluralism” PhD Thesis, Berkeley.

Gawande, K. and U. Bandyopadhyay (2000). "Is Protection for Sale? Evidence on the GrossmanHelpman Theory of Endogenous Protection." Review of Economics and Statistics 82(1): 139-52.

Goldberg, P. K. and G. Maggi (1999). "Protection for Sale: An Empirical Investigation." American Economic Review 89(5): 1135-55.

Grossman, G. M. and E. Helpman (1994). "Protection for Sale." American Economic Review 84(4): 833-50.

Grossman, G.M. and E. Helpman (1995) "Trade Wars and Trade Talks" Journal of Political Economy 103, pp. 675-708.

Grossman G.M., and E. Helpman, (1996) "Electoral competition and special interest politics", Review of Economic Studies 63 (2), pp. 265-286. 
Grossman G.M. and E. Helpman, Special Interest Politics, MIT Press, Cambridge (2001).

Grenzke, J. M. (1989). "PAC’s and the Congressional Supermarket: The Currency Is Complex." American Journal of Political Science 33:1-24.

Hall, Richard L., Frank W. Wayman (1990) "Buying Time: Moneyed Interests and the Mobilization of Bias in Congressional Committees" The American Political Science Review Vol. 84, No. 3, pp. 797-820

Hansen, J. M. (1991) "Gaining Access: Congress and the Farm Lobby, 1919-1981”. Chicago: University of Chicago Press.

Heinz, John P., Edward O. Laumann, Robert L. Nelson, Robert H. Salisbury (1993) “The Hollow Core: Private Interests in National Policy Making” Harvard University Press

Herndon, J. F. (1982) "Access, Record and Competition as Influences on Interest Group Contributions to Congressional Campaigns." The Journal of Politics 44:996-1019.

Hrebenar, Ronald and Bryson Morgan (2009) "Lobbying in America” ABC-Clio Inc. Santa Barbara, California.

Igan D., Mishra P., Tressel T. (2009), "A Fistful of Dollars: Lobbying and the Financial Crisis", IMF WP/09/287.

McGrath, Conor, (2006) "The Ideal Lobbyists: Personal characteristics of effective lobbyists" Journal of Communication Management Vol. 10 No. 1, pp. 67-79

Mian, Atif, Amir Sufi and Francesco Trebbi (2010), "The political economy of the subprime mortgage credit expansion”, NBER WP 16107.

Langbein, L. I. (1986) "Money and Access: Some Empirical Evidence." The Journal of Politics

48:1052-62.

Lohmann, S. (1995) "Information, access, and contributions: a signaling model of lobbying”, Public Choice 85 (1995) (3-4), pp. 267-284.

Potters, J. and F. Van Winden (1990) "Modeling Political Pressure as Transmission of Information" European Journal of Political Economy 6, pp. 61-88

Potters, J. and F. Van Winden (1992). "Lobbying and asymmetric information" Public Choice 74(3), pp. 269-292

Salisbury, Robert H., Paul Johnson, John P. Heinz, Edward O. Laumann and Robert L. Nelson. 1989. "Who You Know versus What You Know: The Uses of Government Experience for Washington Lobbyists” American Journal of Political Science Vol. 33, No. 1, pp. 175-195 
Snyder, James M. (1990). "Campaign Contributions as Investments: The House of Representatives, 1980-1986." Journal of Political Economy 98(6): 1195-227.

Snyder, James M. (1991) "On buying legislatures", Economics and Politics 3 (2), pp. 93-109.

Stewart, Charles III and Jonathan Woon. 2009. Congressional Committee Assignments, 103rd to 111th Congresses, 1993-2009.

Strömberg, D. (2008) "How the electoral college influences campaigns and policy: the probability of being Florida" American Economic Review 98 (3), 769-807.

Wright John R. (1990) "Contributions, Lobbying, and Committee Voting in the U.S. House of Representatives" The American Political Science Review, Vol. 84, No. 2, pp. 417-43 
Table 1: The Lobbyists

Summary Statistics

\begin{tabular}{|c|c|c|c|}
\hline Variable & Obs & Mean & Std. \\
\hline In-house lobbyist & 36982 & 0.416 & 0.493 \\
\hline Number of lobbying records/year & 36982 & 4.692 & 9.755 \\
\hline Number of active years & 36982 & 3.898 & 2.880 \\
\hline Tenure & 36982 & 1.709 & 1.605 \\
\hline $\begin{array}{l}\text { Any biographical information on } \\
\text { www.lobbyists.info }\end{array}$ & 13720 & 0.940 & 0.238 \\
\hline Republican & 13720 & 0.106 & 0.308 \\
\hline Democrat & 13720 & 0.092 & 0.289 \\
\hline Former Member of Congress & 13720 & 0.012 & 0.109 \\
\hline \multicolumn{4}{|l|}{ Of wich: } \\
\hline Republican & 13720 & 0.006 & 0.079 \\
\hline Democrat & 13720 & 0.006 & 0.074 \\
\hline Senate & 13720 & 0.003 & 0.056 \\
\hline House & 13720 & 0.010 & 0.099 \\
\hline \multicolumn{4}{|l|}{ Past Experience in/as: } \\
\hline White House & 13720 & 0.023 & 0.149 \\
\hline Aide & 13720 & 0.110 & 0.314 \\
\hline Clerk & 13720 & 0.014 & 0.119 \\
\hline Counsel & 13720 & 0.077 & 0.267 \\
\hline House (but not as house representative) & 13720 & 0.007 & 0.082 \\
\hline Senate (but not as senator) & 13720 & 0.103 & 0.304 \\
\hline \multicolumn{4}{|l|}{ Experience in the: } \\
\hline $1960 \mathrm{~s}$ & 13720 & 0.014 & 0.116 \\
\hline 1970 s & 13720 & 0.048 & 0.213 \\
\hline $1980 s$ & 13720 & 0.068 & 0.251 \\
\hline $1990 \mathrm{~s}$ & 13720 & 0.081 & 0.273 \\
\hline $2000 s$ & 13720 & 0.063 & 0.243 \\
\hline
\end{tabular}


Former

Member of

Year In House Republican Democrat Congress

Sample: All

$\begin{array}{llll}1999 & 0.491 & 0.118 & 0.108 \\ 2000 & 0.595 & 0.119 & 0.109 \\ 2001 & 0.563 & 0.122 & 0.115 \\ 2002 & 0.561 & 0.122 & 0.112 \\ 2003 & 0.555 & 0.122 & 0.113 \\ 2004 & 0.556 & 0.125 & 0.110 \\ 2005 & 0.558 & 0.128 & 0.107 \\ 2006 & 0.425 & 0.125 & 0.104 \\ 2007 & 0.359 & 0.119 & 0.104 \\ 2008 & 0.379 & 0.114 & 0.102\end{array}$

Sample: External Lobbyists

\begin{tabular}{|c|c|c|c|c|c|c|c|c|c|c|c|c|c|}
\hline 1999 & 0.147 & 0.144 & 0.026 & 0.012 & 0.014 & 0.006 & 0.022 & 0.046 & 0.173 & 0.030 & 0.161 & 0.039 & 0.175 \\
\hline 2000 & 0.158 & 0.166 & 0.032 & 0.014 & 0.017 & 0.009 & 0.025 & 0.047 & 0.194 & 0.035 & 0.184 & 0.047 & 0.196 \\
\hline 2001 & 0.160 & 0.169 & 0.034 & 0.017 & 0.017 & 0.008 & 0.028 & 0.052 & 0.188 & 0.034 & 0.177 & 0.049 & 0.192 \\
\hline 2002 & 0.168 & 0.169 & 0.034 & 0.018 & 0.017 & 0.008 & 0.029 & 0.054 & 0.192 & 0.028 & 0.171 & 0.046 & 0.192 \\
\hline 2003 & 0.172 & 0.167 & 0.031 & 0.016 & 0.015 & 0.008 & 0.026 & 0.051 & 0.187 & 0.028 & 0.164 & 0.041 & 0.189 \\
\hline 2004 & 0.176 & 0.160 & 0.028 & 0.014 & 0.014 & 0.006 & 0.024 & 0.047 & 0.190 & 0.026 & 0.156 & 0.038 & 0.190 \\
\hline 2005 & 0.185 & 0.153 & 0.026 & 0.013 & 0.013 & 0.007 & 0.022 & 0.043 & 0.187 & 0.023 & 0.143 & 0.036 & 0.190 \\
\hline 2006 & 0.159 & 0.131 & 0.019 & 0.010 & 0.009 & 0.005 & 0.016 & 0.036 & 0.163 & 0.019 & 0.120 & 0.027 & 0.160 \\
\hline 2007 & 0.146 & 0.129 & 0.017 & 0.009 & 0.008 & 0.005 & 0.014 & 0.032 & 0.153 & 0.017 & 0.109 & 0.023 & 0.150 \\
\hline 2008 & 0.141 & 0.127 & 0.015 & 0.008 & 0.008 & 0.004 & 0.013 & 0.030 & 0.148 & 0.017 & 0.100 & 0.022 & 0.144 \\
\hline \multicolumn{14}{|c|}{ Sample: In-House Lobbyists } \\
\hline 1999 & 0.076 & 0.056 & 0.005 & 0.003 & 0.002 & 0.001 & 0.004 & 0.015 & 0.077 & 0.005 & 0.047 & 0.008 & 0.065 \\
\hline 2000 & 0.084 & 0.057 & 0.005 & 0.003 & 0.002 & 0.001 & 0.005 & 0.014 & 0.084 & 0.005 & 0.042 & 0.008 & 0.070 \\
\hline 2001 & 0.084 & 0.062 & 0.003 & 0.002 & 0.001 & 0.001 & 0.003 & 0.013 & 0.093 & 0.005 & 0.044 & 0.006 & 0.075 \\
\hline 2002 & 0.078 & 0.057 & 0.004 & 0.002 & 0.001 & 0.001 & 0.004 & 0.012 & 0.086 & 0.004 & 0.041 & 0.007 & 0.071 \\
\hline 2003 & 0.074 & 0.060 & 0.004 & 0.003 & 0.002 & 0.001 & 0.004 & 0.014 & 0.083 & 0.003 & 0.040 & 0.008 & 0.067 \\
\hline 2004 & 0.076 & 0.063 & 0.005 & 0.003 & 0.001 & 0.001 & 0.004 & 0.014 & 0.085 & 0.003 & 0.041 & 0.008 & 0.067 \\
\hline 2005 & 0.074 & 0.063 & 0.004 & 0.003 & 0.002 & 0.001 & 0.004 & 0.013 & 0.085 & 0.003 & 0.040 & 0.007 & 0.067 \\
\hline 2006 & 0.070 & 0.060 & 0.005 & 0.002 & 0.002 & 0.001 & 0.004 & 0.012 & 0.075 & 0.002 & 0.036 & 0.010 & 0.063 \\
\hline 2007 & 0.064 & 0.055 & 0.004 & 0.002 & 0.002 & 0.001 & 0.004 & 0.011 & 0.070 & 0.003 & 0.033 & 0.010 & 0.059 \\
\hline 2008 & 0.065 & 0.056 & 0.005 & 0.002 & 0.002 & 0.001 & 0.005 & 0.011 & 0.072 & 0.002 & 0.033 & 0.009 & 0.060 \\
\hline
\end{tabular}

Experience in/as:

0.017
0.018
0.018
0.019
0.018
0.016
0.015
0.014
0.013
0.012

0.008
0.008
0.009
0.010
0.010
0.009
0.008
0.007
0.006
0.006

$\begin{array}{lll}0.009 & 0.004 & 0.015 \\ 0.009 & 0.005 & 0.015\end{array}$

$\begin{array}{llll}0.033 & 0.134 & 0.019 & 0.114\end{array}$

$0.026 \quad 0.130$

$\begin{array}{llllllll}0.005 & 0.015 & 0.030 & 0.136 & 0.019 & 0.110 & 0.027 & 0.130\end{array}$

$\begin{array}{lllllllll}0.009 & 0.004 & 0.015 & 0.032 & 0.139 & 0.019 & 0.109 & 0.027 & 0.132\end{array}$

$\begin{array}{lllllllll}0.009 & 0.004 & 0.016 & 0.033 & 0.139 & 0.016 & 0.105 & 0.026 & 0.131 \\ 0.008 & 0.004 & 0.015 & 0.032 & 0.135 & 0.015 & 0.101 & 0.024 & 0.128\end{array}$

$\begin{array}{lllllllll}0.007 & 0.004 & 0.013 & 0.028 & 0.135 & 0.013 & 0.091 & 0.021 & 0.127\end{array}$

$\begin{array}{lllllllll}0.006 & 0.004 & 0.012 & 0.027 & 0.130 & 0.013 & 0.088 & 0.020 & 0.123\end{array}$

$\begin{array}{lllllllll}0.006 & 0.003 & 0.011 & 0.025 & 0.125 & 0.013 & 0.083 & 0.019 & 0.119\end{array}$

$\begin{array}{lllllllll}0.006 & 0.003 & 0.010 & 0.023 & 0.121 & 0.012 & 0.077 & 0.017 & 0.114\end{array}$

\begin{tabular}{lllllll} 
Of Which: & \multicolumn{1}{l}{ White } & & \\
\hline \multirow{2}{*}{ Republican } & & & & \\
& Democrat & Senator & House Rep. House Aide Clerk Counsel House Senate
\end{tabular}

$\begin{array}{lllllllll}0.007 & 0.003 & 0.014 & 0.030 & 0.136 & 0.014 & 0.097 & 0.022 & 0.127\end{array}$ 
Table 3: 'Trends in Lobbyists' Expertise

\begin{tabular}{|c|c|c|c|c|c|c|c|c|c|}
\hline \multicolumn{5}{|c|}{ Panel A: All } & \multicolumn{5}{|c|}{ Panel B: At Least 4 Active Years } \\
\hline Year & Specialist & Issue-Based HHI & $\begin{array}{l}\text { Number of Issues } \\
\text { of Specialization }\end{array}$ & Generalist & Year & Specialist & $\begin{array}{c}\text { Issue- } \\
\text { Based HHI }\end{array}$ & $\begin{array}{c}\text { Number of } \\
\text { Issues of } \\
\text { Specialization }\end{array}$ & Generalist \\
\hline 1999 & 0.24 & 0.33 & 0.33 & 0.32 & 1999 & 0.17 & 0.32 & 0.19 & 0.23 \\
\hline 2000 & 0.22 & 0.33 & 0.29 & 0.29 & 2000 & 0.17 & 0.32 & 0.20 & 0.23 \\
\hline 2001 & 0.22 & 0.35 & 0.27 & 0.25 & 2001 & 0.18 & 0.33 & 0.21 & 0.23 \\
\hline 2002 & 0.22 & 0.34 & 0.26 & 0.25 & 2002 & 0.19 & 0.33 & 0.22 & 0.23 \\
\hline 2003 & 0.23 & 0.35 & 0.28 & 0.24 & 2003 & 0.19 & 0.34 & 0.23 & 0.22 \\
\hline 2004 & 0.23 & 0.35 & 0.29 & 0.24 & 2004 & 0.20 & 0.33 & 0.23 & 0.22 \\
\hline 2005 & 0.24 & 0.35 & 0.31 & 0.25 & 2005 & 0.20 & 0.33 & 0.24 & 0.22 \\
\hline 2006 & 0.26 & 0.35 & 0.34 & 0.26 & 2006 & 0.20 & 0.33 & 0.23 & 0.21 \\
\hline 2007 & 0.28 & 0.34 & 0.36 & 0.27 & 2007 & 0.19 & 0.32 & 0.22 & 0.21 \\
\hline 2008 & 0.29 & 0.34 & 0.40 & 0.29 & 2008 & 0.19 & 0.32 & 0.21 & 0.21 \\
\hline Across all years & 0.25 & 0.34 & 0.32 & 0.27 & Across all years & 0.19 & 0.33 & 0.22 & 0.22 \\
\hline \multicolumn{6}{|c|}{ Panel C: External Lobbyists } & \multicolumn{3}{|c|}{ Panel D: In-House Lobbyists } & \\
\hline Year & Specialist & Issue-Based HHI & $\begin{array}{l}\text { Number of Issues } \\
\text { of Specialization }\end{array}$ & Generalist & Year & Specialist & $\begin{array}{c}\text { Issue- } \\
\text { Based HHI }\end{array}$ & $\begin{array}{c}\text { Number of } \\
\text { Issues of } \\
\text { Specialization }\end{array}$ & Generalist \\
\hline 1999 & 0.28 & 0.39 & 0.35 & 0.19 & 1999 & 0.20 & 0.28 & 0.30 & 0.46 \\
\hline 2000 & 0.29 & 0.43 & 0.33 & 0.09 & 2000 & 0.18 & 0.27 & 0.26 & 0.44 \\
\hline 2001 & 0.27 & 0.43 & 0.31 & 0.07 & 2001 & 0.18 & 0.28 & 0.24 & 0.39 \\
\hline 2002 & 0.27 & 0.42 & 0.30 & 0.08 & 2002 & 0.18 & 0.28 & 0.23 & 0.38 \\
\hline 2003 & 0.27 & 0.42 & 0.31 & 0.07 & 2003 & 0.19 & 0.29 & 0.26 & 0.37 \\
\hline 2004 & 0.28 & 0.42 & 0.31 & 0.07 & 2004 & 0.19 & 0.29 & 0.26 & 0.37 \\
\hline 2005 & 0.28 & 0.41 & 0.31 & 0.09 & 2005 & 0.22 & 0.30 & 0.31 & 0.38 \\
\hline 2006 & 0.28 & 0.38 & 0.33 & 0.15 & 2006 & 0.23 & 0.31 & 0.34 & 0.39 \\
\hline 2007 & 0.30 & 0.37 & 0.38 & 0.18 & 2007 & 0.22 & 0.30 & 0.34 & 0.42 \\
\hline 2008 & 0.31 & 0.36 & 0.39 & 0.21 & 2008 & 0.26 & 0.30 & 0.41 & 0.41 \\
\hline Across all years & 0.29 & 0.40 & 0.34 & 0.13 & Across all years & 0.20 & 0.29 & 0.29 & 0.40 \\
\hline
\end{tabular}


Table 4: Trends in Lobbyists' Connections (through Campaign Contributions) to Politicians

\begin{tabular}{|c|c|c|c|c|c|c|c|}
\hline \multicolumn{4}{|c|}{ Panel A: All } & \multicolumn{4}{|c|}{ Panel B: At Least 4 Active Years } \\
\hline Year & Any & Number & Many $(>=5)$ & Year & Any & Number & $\operatorname{Many}(>=5)$ \\
\hline 1999 & 0.22 & 1.04 & 0.06 & 1999 & 0.29 & 1.49 & 0.09 \\
\hline 2000 & 0.22 & 1.05 & 0.07 & 2000 & 0.28 & 1.38 & 0.09 \\
\hline 2001 & 0.24 & 1.19 & 0.07 & 2001 & 0.28 & 1.41 & 0.09 \\
\hline 2002 & 0.24 & 1.18 & 0.07 & 2002 & 0.27 & 1.34 & 0.08 \\
\hline 2003 & 0.30 & 1.49 & 0.09 & 2003 & 0.33 & 1.70 & 0.11 \\
\hline 2004 & 0.30 & 1.44 & 0.09 & 2004 & 0.33 & 1.66 & 0.10 \\
\hline 2005 & 0.28 & 1.48 & 0.09 & 2005 & 0.32 & 1.78 & 0.11 \\
\hline 2006 & 0.27 & 1.47 & 0.09 & 2006 & 0.34 & 1.91 & 0.12 \\
\hline 2007 & 0.32 & 1.58 & 0.10 & 2007 & 0.39 & 2.11 & 0.13 \\
\hline 2008 & 0.29 & 1.41 & 0.09 & 2008 & 0.39 & 2.10 & 0.13 \\
\hline Across all years & 0.27 & 1.34 & 0.08 & Across all years & 0.32 & 1.69 & 0.11 \\
\hline \multicolumn{4}{|c|}{ Panel C: External Lobbyists } & \multicolumn{4}{|c|}{ Panel D: In-House Lobbyists } \\
\hline Year & Any & Number & Many $(>=5)$ & Year & Any & Number & Many $(>=5)$ \\
\hline 1999 & 0.31 & 1.66 & 0.10 & 1999 & 0.13 & 0.39 & 0.02 \\
\hline 2000 & 0.35 & 1.98 & 0.12 & 2000 & 0.14 & 0.42 & 0.03 \\
\hline 2001 & 0.36 & 2.15 & 0.14 & 2001 & 0.15 & 0.44 & 0.02 \\
\hline 2002 & 0.37 & 2.12 & 0.14 & 2002 & 0.15 & 0.45 & 0.02 \\
\hline 2003 & 0.44 & 2.65 & 0.17 & 2003 & 0.19 & 0.55 & 0.03 \\
\hline 2004 & 0.43 & 2.60 & 0.17 & 2004 & 0.19 & 0.52 & 0.03 \\
\hline 2005 & 0.42 & 2.72 & 0.17 & 2005 & 0.16 & 0.49 & 0.03 \\
\hline 2006 & 0.37 & 2.23 & 0.14 & 2006 & 0.15 & 0.43 & 0.02 \\
\hline 2007 & 0.39 & 2.18 & 0.14 & 2007 & 0.19 & 0.51 & 0.03 \\
\hline 2008 & 0.36 & 1.99 & 0.12 & 2008 & 0.18 & 0.46 & 0.02 \\
\hline Across all years & 0.38 & 2.21 & 0.14 & Across all years & 0.16 & 0.47 & 0.03 \\
\hline
\end{tabular}


Table 5: Determinants of Lobbyists' Expertise

\begin{tabular}{|c|c|c|c|c|c|c|c|c|c|c|c|c|}
\hline \multirow{4}{*}{$\begin{array}{l}\text { Sample: } \\
\text { Restrict to at Least } 4 \text { Active } \\
\text { Years? }\end{array}$} & \multicolumn{6}{|c|}{ Dependent Variable: Specialist $(\mathrm{Y}=1)$} & \multicolumn{6}{|c|}{ Dependent Variable: Issue-Based HHI } \\
\hline & \multicolumn{2}{|c|}{ All } & \multicolumn{2}{|c|}{ External } & \multicolumn{2}{|c|}{ In-House } & \multicolumn{2}{|c|}{ All } & \multicolumn{2}{|c|}{ External } & \multicolumn{2}{|c|}{ In-House } \\
\hline & & & & & & & & & & & & \\
\hline & $\begin{array}{l}\text { No } \\
(1)\end{array}$ & $\begin{array}{l}\text { Yes } \\
(2)\end{array}$ & $\begin{array}{l}\text { No } \\
\text { (3) }\end{array}$ & $\begin{array}{l}\text { Yes } \\
(4)\end{array}$ & $\begin{array}{l}\text { No } \\
(5)\end{array}$ & $\begin{array}{l}\text { Yes } \\
(6)\end{array}$ & $\begin{array}{l}\text { No } \\
\text { (7) }\end{array}$ & $\begin{array}{l}\text { Yes } \\
(8)\end{array}$ & $\begin{array}{l}\text { No } \\
(9)\end{array}$ & $\begin{array}{l}\text { Yes } \\
(10)\end{array}$ & $\begin{array}{l}\text { No } \\
\text { (11) }\end{array}$ & $\begin{array}{l}\text { Yes } \\
(12)\end{array}$ \\
\hline \multicolumn{13}{|l|}{ Former Member of } \\
\hline Congress & $\begin{array}{c}-0.02 \\
{[0.040]}\end{array}$ & $\begin{array}{c}-0.03 \\
{[0.040]}\end{array}$ & $\begin{array}{c}-0.06 \\
{[0.042]}\end{array}$ & $\begin{array}{c}-0.05 \\
{[0.042]}\end{array}$ & $\begin{array}{c}0.36 \\
{[0.129]^{* *}}\end{array}$ & $\begin{array}{c}0.19 \\
{[0.142]}\end{array}$ & $\begin{array}{c}-0.01 \\
{[0.028]}\end{array}$ & $\begin{array}{c}-0.04 \\
{[0.030]}\end{array}$ & $\begin{array}{c}-0.03 \\
{[0.030]}\end{array}$ & $\begin{array}{c}-0.06 \\
{[0.031]}\end{array}$ & $\begin{array}{c}0.15 \\
{[0.093]}\end{array}$ & $\begin{array}{c}0.18 \\
{[0.112]}\end{array}$ \\
\hline Republican & $\begin{array}{c}-0.04 \\
{[0.016]^{*}}\end{array}$ & $\begin{array}{c}-0.04 \\
{[0.017]^{* *}}\end{array}$ & $\begin{array}{c}-0.04 \\
{[0.018]^{*}}\end{array}$ & $\begin{array}{c}-0.05 \\
{[0.018]^{*}}\end{array}$ & $\begin{array}{c}-0.04 \\
{[0.036]}\end{array}$ & $\begin{array}{c}-0.04 \\
{[0.044]}\end{array}$ & $\begin{array}{c}-0.06 \\
{[0.012]^{* *}}\end{array}$ & $\begin{array}{c}-0.08 \\
{[0.013]^{* *}}\end{array}$ & $\begin{array}{c}-0.08 \\
{[0.013]^{* *}}\end{array}$ & $\begin{array}{c}-0.10 \\
{[0.014]^{* *}}\end{array}$ & $\begin{array}{c}-0.04 \\
{[0.026]}\end{array}$ & $\begin{array}{c}-0.04 \\
{[0.035]}\end{array}$ \\
\hline Democrat & $\begin{array}{c}-0.05 \\
{[0.017]^{* *}}\end{array}$ & $\begin{array}{c}-0.06 \\
{[0.018]^{* *}}\end{array}$ & $\begin{array}{c}-0.06 \\
{[0.019]^{* *}}\end{array}$ & $\begin{array}{c}-0.07 \\
{[0.019]^{* *}}\end{array}$ & $\begin{array}{c}-0.01 \\
{[0.042]}\end{array}$ & $\begin{array}{c}-0.04 \\
{[0.051]}\end{array}$ & $\begin{array}{c}-0.07 \\
{[0.012]^{* *}}\end{array}$ & $\begin{array}{c}-0.08 \\
{[0.014]^{* *}}\end{array}$ & $\begin{array}{c}-0.09 \\
{[0.013]^{* *}}\end{array}$ & $\begin{array}{c}-0.10 \\
{[0.014]^{* *}}\end{array}$ & $\begin{array}{c}-0.03 \\
{[0.031]}\end{array}$ & $\begin{array}{c}-0.06 \\
{[0.040]}\end{array}$ \\
\hline \multicolumn{13}{|l|}{ Experience in/as: } \\
\hline House (not rep) & $\begin{array}{c}0.02 \\
{[0.048]}\end{array}$ & $\begin{array}{c}0.09 \\
{[0.047]}\end{array}$ & $\begin{array}{c}0.02 \\
{[0.051]}\end{array}$ & $\begin{array}{c}0.08 \\
{[0.049]}\end{array}$ & $\begin{array}{c}0.02 \\
{[0.136]}\end{array}$ & $\begin{array}{c}0.27 \\
{[0.178]}\end{array}$ & $\begin{array}{c}0.03 \\
{[0.034]}\end{array}$ & $\begin{array}{c}0.05 \\
{[0.036]}\end{array}$ & $\begin{array}{c}0.03 \\
{[0.036]}\end{array}$ & $\begin{array}{c}0.04 \\
{[0.036]}\end{array}$ & $\begin{array}{c}-0.02 \\
{[0.099]}\end{array}$ & $\begin{array}{c}0.18 \\
{[0.141]}\end{array}$ \\
\hline Senate (not senator) & $\begin{array}{c}-0.01 \\
{[0.016]}\end{array}$ & $\begin{array}{c}0.03 \\
{[0.016]}\end{array}$ & $\begin{array}{c}0.00 \\
{[0.017]}\end{array}$ & $\begin{array}{c}0.04 \\
{[0.018]^{*}}\end{array}$ & $\begin{array}{c}-0.05 \\
{[0.038]}\end{array}$ & $\begin{array}{c}-0.02 \\
{[0.046]}\end{array}$ & $\begin{array}{c}-0.02 \\
{[0.011]}\end{array}$ & $\begin{array}{c}-0.01 \\
{[0.012]}\end{array}$ & $\begin{array}{c}-0.02 \\
{[0.012]}\end{array}$ & $\begin{array}{c}-0.01 \\
{[0.013]}\end{array}$ & $\begin{array}{c}-0.03 \\
{[0.027]}\end{array}$ & $\begin{array}{c}-0.04 \\
{[0.036]}\end{array}$ \\
\hline White House & $\begin{array}{c}-0.09 \\
{[0.027]^{* *}}\end{array}$ & $\begin{array}{c}-0.05 \\
{[0.026]^{*}}\end{array}$ & $\begin{array}{c}-0.10 \\
{[0.029]^{* *}}\end{array}$ & $\begin{array}{c}-0.06 \\
{[0.027]^{*}}\end{array}$ & $\begin{array}{c}-0.05 \\
{[0.079]}\end{array}$ & $\begin{array}{c}0.07 \\
{[0.091]}\end{array}$ & $\begin{array}{c}-0.04 \\
{[0.019]^{*}}\end{array}$ & $\begin{array}{c}-0.03 \\
{[0.020]}\end{array}$ & $\begin{array}{c}-0.05 \\
{[0.020]^{*}}\end{array}$ & $\begin{array}{c}-0.04 \\
{[0.020]^{*}}\end{array}$ & $\begin{array}{c}-0.05 \\
{[0.058]}\end{array}$ & $\begin{array}{c}0.02 \\
{[0.072]}\end{array}$ \\
\hline Aide & $\begin{array}{c}0.00 \\
{[0.016]}\end{array}$ & $\begin{array}{c}0.03 \\
{[0.016]^{*}}\end{array}$ & $\begin{array}{l}-0.01 \\
{[0.018]}\end{array}$ & $\begin{array}{c}0.04 \\
{[0.018]^{*}}\end{array}$ & $\begin{array}{c}0.03 \\
{[0.039]}\end{array}$ & $\begin{array}{c}0.01 \\
{[0.045]}\end{array}$ & $\begin{array}{c}-0.02 \\
{[0.011]}\end{array}$ & $\begin{array}{c}0.00 \\
{[0.012]}\end{array}$ & $\begin{array}{c}-0.04 \\
{[0.013]^{* *}}\end{array}$ & $\begin{array}{c}0.00 \\
{[0.013]}\end{array}$ & $\begin{array}{c}0.03 \\
{[0.028]}\end{array}$ & $\begin{array}{c}0.01 \\
{[0.036]}\end{array}$ \\
\hline Clerk & $\begin{array}{c}0.05 \\
{[0.034]}\end{array}$ & $\begin{array}{c}-0.03 \\
{[0.038]}\end{array}$ & $\begin{array}{c}0.05 \\
{[0.035]}\end{array}$ & $\begin{array}{c}-0.03 \\
{[0.039]}\end{array}$ & $\begin{array}{c}-0.04 \\
{[0.127]}\end{array}$ & $\begin{array}{c}-0.06 \\
{[0.179]}\end{array}$ & $\begin{array}{c}0.04 \\
{[0.024]}\end{array}$ & $\begin{array}{c}0.03 \\
{[0.029]}\end{array}$ & $\begin{array}{c}0.03 \\
{[0.025]}\end{array}$ & $\begin{array}{c}0.03 \\
{[0.029]}\end{array}$ & $\begin{array}{c}-0.05 \\
{[0.092]}\end{array}$ & $\begin{array}{c}-0.12 \\
{[0.141]}\end{array}$ \\
\hline Counsel & $\begin{array}{c}-0.02 \\
{[0.016]}\end{array}$ & $\begin{array}{c}0.00 \\
{[0.016]}\end{array}$ & $\begin{array}{c}-0.04 \\
{[0.018]^{*}}\end{array}$ & $\begin{array}{c}0.00 \\
{[0.018]}\end{array}$ & $\begin{array}{c}0.03 \\
{[0.044]}\end{array}$ & $\begin{array}{c}-0.02 \\
{[0.052]}\end{array}$ & $\begin{array}{c}0.02 \\
{[0.012]}\end{array}$ & $\begin{array}{c}0.03 \\
{[0.012]^{*}}\end{array}$ & $\begin{array}{c}0.01 \\
{[0.012]}\end{array}$ & $\begin{array}{c}0.02 \\
{[0.013]}\end{array}$ & $\begin{array}{c}0.00 \\
{[0.032]}\end{array}$ & $\begin{array}{c}-0.03 \\
{[0.041]}\end{array}$ \\
\hline Experience in: & $\begin{array}{c}0.07 \\
{[0.036]}\end{array}$ & $\begin{array}{c}0.07 \\
{[0.036]^{*}}\end{array}$ & $\begin{array}{c}0.06 \\
{[0.038]}\end{array}$ & $\begin{array}{c}0.06 \\
{[0.037]}\end{array}$ & $\begin{array}{c}0.05 \\
{[0.124]}\end{array}$ & $\begin{array}{c}0.14 \\
{[0.148]}\end{array}$ & $\begin{array}{c}0.08 \\
{[0.026]^{* *}}\end{array}$ & $\begin{array}{c}0.08 \\
{[0.027]^{* *}}\end{array}$ & $\begin{array}{c}0.08 \\
{[0.027]^{* *}}\end{array}$ & $\begin{array}{c}0.07 \\
{[0.028]^{*}}\end{array}$ & $\begin{array}{c}0.13 \\
{[0.090]}\end{array}$ & $\begin{array}{c}0.08 \\
{[0.117]}\end{array}$ \\
\hline 1970s & $\begin{array}{c}-0.03 \\
{[0.021]}\end{array}$ & $\begin{array}{c}0.02 \\
{[0.021]}\end{array}$ & $\begin{array}{c}-0.03 \\
{[0.022]}\end{array}$ & $\begin{array}{c}0.02 \\
{[0.022]}\end{array}$ & $\begin{array}{c}-0.05 \\
{[0.068]}\end{array}$ & $\begin{array}{c}-0.02 \\
{[0.075]}\end{array}$ & $\begin{array}{c}0.03 \\
{[0.015]^{*}}\end{array}$ & $\begin{array}{c}0.04 \\
{[0.016]^{*}}\end{array}$ & $\begin{array}{c}0.04 \\
{[0.016]^{*}}\end{array}$ & $\begin{array}{c}0.04 \\
{[0.016]^{*}}\end{array}$ & $\begin{array}{c}-0.08 \\
{[0.049]}\end{array}$ & $\begin{array}{c}-0.06 \\
{[0.059]}\end{array}$ \\
\hline $1980 \mathrm{~s}$ & $\begin{array}{c}-0.03 \\
{[0.018]}\end{array}$ & $\begin{array}{c}0.00 \\
{[0.018]}\end{array}$ & $\begin{array}{c}-0.03 \\
{[0.019]}\end{array}$ & $\begin{array}{c}-0.01 \\
{[0.019]}\end{array}$ & $\begin{array}{c}-0.01 \\
{[0.055]}\end{array}$ & $\begin{array}{c}0.04 \\
{[0.059]}\end{array}$ & $\begin{array}{c}0.01 \\
{[0.013]}\end{array}$ & $\begin{array}{c}0.01 \\
{[0.013]}\end{array}$ & $\begin{array}{c}0.00 \\
{[0.014]}\end{array}$ & $\begin{array}{c}0.00 \\
{[0.014]}\end{array}$ & $\begin{array}{c}0.01 \\
{[0.040]}\end{array}$ & $\begin{array}{c}0.03 \\
{[0.047]}\end{array}$ \\
\hline $1990 \mathrm{~s}$ & $\begin{array}{c}-0.02 \\
{[0.019]}\end{array}$ & $\begin{array}{c}0.02 \\
{[0.019]}\end{array}$ & $\begin{array}{c}-0.03 \\
{[0.020]}\end{array}$ & $\begin{array}{c}0.01 \\
{[0.020]}\end{array}$ & $\begin{array}{c}0.01 \\
{[0.051]}\end{array}$ & $\begin{array}{c}0.06 \\
{[0.059]}\end{array}$ & $\begin{array}{c}-0.02 \\
{[0.013]}\end{array}$ & $\begin{array}{c}0.00 \\
{[0.014]}\end{array}$ & $\begin{array}{c}-0.02 \\
{[0.014]}\end{array}$ & $\begin{array}{c}-0.01 \\
{[0.015]}\end{array}$ & $\begin{array}{c}0.01 \\
{[0.037]}\end{array}$ & $\begin{array}{c}0.05 \\
{[0.047]}\end{array}$ \\
\hline $2000 \mathrm{~s}$ & $\begin{array}{c}0.05 \\
{[0.020]^{*}}\end{array}$ & $\begin{array}{c}-0.02 \\
{[0.021]}\end{array}$ & $\begin{array}{c}0.06 \\
{[0.022]^{* *}}\end{array}$ & $\begin{array}{c}-0.01 \\
{[0.023]}\end{array}$ & $\begin{array}{c}-0.04 \\
{[0.050]}\end{array}$ & $\begin{array}{c}-0.14 \\
{[0.061]^{*}}\end{array}$ & $\begin{array}{c}0.01 \\
{[0.014]}\end{array}$ & $\begin{array}{c}-0.02 \\
{[0.016]}\end{array}$ & $\begin{array}{c}0.01 \\
{[0.015]}\end{array}$ & $\begin{array}{c}-0.01 \\
{[0.017]}\end{array}$ & $\begin{array}{c}-0.01 \\
{[0.036]}\end{array}$ & $\begin{array}{c}-0.06 \\
{[0.048]}\end{array}$ \\
\hline R-Squared & 0.00 & 0.00 & 0.01 & 0.01 & 0.00 & 0.01 & 0.01 & 0.02 & 0.03 & 0.03 & 0.00 & 0.01 \\
\hline Observations & 13,720 & 8,004 & 9,325 & 5,788 & 4,395 & 2,216 & 13,720 & 8,004 & 9,325 & 5,788 & 4,395 & 2,216 \\
\hline
\end{tabular}

The regressions also include an "experience" dummy.

Standard errors in brackets

* significant at $5 \%$; ** significant at $1 \%$ 
Table 6: Determinants of Lobbyists' Connections to Politicians (through Campaign Contributions)

Dependent Variable: Any Connection? (Y=1)

Sample:

Restrict to at Least 4

Active Years?

Former Memb of

Congress

Republican

Democrat

Experience in/as:

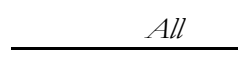

$$
\text { External }
$$

No

No Yes

(2)

(3)

Yes

0.12

$[0.041]^{* *}$

0.10

$0.15-0.048$

$[0.017]^{* *} \quad[0.021]^{* *}$

$0.19 \quad 0.19$

$[0.018]^{* *} \quad[0.022]^{* *}$

House (not rep)

Senate (not senator)

White Hous

$\begin{array}{cc}0.10 & 0.07 \\ {[0.049]^{*}} & {[0.057]} \\ 0.09 & 0.08 \\ {[0.016]^{* *}} & {[0.020]^{* *}}\end{array}$

$[0.028]^{* *} \quad[0.032]^{* *}$

Aide

$[0.017]^{*} \quad[0.020]$

$0.05 \quad 0.03$

Counsel

$0.12 \quad 0.10$

Experience in:

$0.07-0.06$

$[0.038]$

1970

0.02

1980s

$[0.019]^{* *} \quad[0.021]$

$1990 \mathrm{~s}$

$[0.019]^{* *} \quad[0.023]^{* *}$

2000 s

$-0.05$

$0.020]^{*}$

0.09

-0.04
$[0.026]$

0.08
8,004

$0.10-0.09$

$[0.044]^{*} \quad[0.049]$

$0.12 \quad 0.11$

$[0.019]^{* *} \quad[0.022]^{* *}$

$[0.020]^{* *} \quad[0.023]^{* *}$

\section{$0.09 \quad 0.05$}

[0.053] [0.058]

$0.08 \quad 0.07$

$[0.018]^{* *} \quad[0.021]^{* *}$

$0.15 \quad 0.13$

$[0.030]^{* *} \quad[0.032]^{* *}$

$0.04 \quad 0.03$

$[0.018]^{*} \quad[0.021]$

$\begin{array}{cc}0.02 & 0.01 \\ {[0.036]} & {[0.046]}\end{array}$

$0.09 \quad 0.07$

$[0.018]^{* *} \quad[0.021]^{* *}$

$$
\begin{array}{ll}
0.05 & 0.05
\end{array}
$$

$[0.040] \quad[0.044]$

$0.10 \quad 0.10$

$[0.023]^{* *} \quad[0.025]^{* *}$

$0.10 \quad 0.07$

$[0.020]^{* *} \quad[0.022]^{* *}$

$0.09 \quad 0.07$

$[0.021]^{* *} \quad[0.023]^{* *}$

$-0.05 \quad-0.03$

$[0.022]^{*} \quad[0.027]$

R-squared

The regressions also include an experience dummy and a constant.

Standard errors in brackets

* significant at $5 \%$; ** significant at $1 \%$

Dependent Variable: Many (>=5) Connections? (Y=1)

\begin{tabular}{cc}
\multicolumn{2}{c}{ In-House } \\
\hline No & Yes \\
$(5)$ & $(6)$ \\
& \\
0.15 & 0.05 \\
{$[0.124]$} & {$[0.174]$} \\
0.18 & 0.15 \\
{$[0.035]^{* *}$} & {$[0.054]^{* *}$} \\
0.10 & 0.15 \\
{$[0.041]^{*}$} & {$[0.063]^{*}$}
\end{tabular}

\begin{tabular}{cc}
\multicolumn{2}{c}{ All } \\
\hline No & Yes \\
$(7)$ & $(8)$ \\
& \\
0.14 & 0.12 \\
{$[0.024]^{* *}$} & {$[0.032]^{* *}$} \\
0.10 & 0.11 \\
{$[0.010]^{* *}$} & {$[0.014]^{* *}$} \\
0.14 & 0.17 \\
{$[0.010]^{* *}$} & {$[0.014]^{* *}$}
\end{tabular}

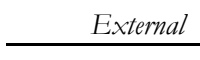

No Yes

(9) (10)

$0.13 \quad 0.12$

$[0.029]^{* *}[0.038]^{* *}$

$0.10 \quad 0.12$

$[0.012]^{* *}[0.017]^{* *}$

$0.15 \quad 0.18$

$[0.013]^{* *}[0.017]^{* *}$

$\begin{array}{ll}-0.08 & -0.10\end{array}$

[0.131] [0.219]

$0.07 \quad 0.13$

[0.036] [0.056 $]^{*}$

$0.23 \quad 0.26$

$[0.076]^{* *} \quad[0.112]^{*}$

$-0.04 \quad-0.09$

$[0.037] \quad[0.055]$

$\begin{array}{cc}0.05 & 0.03 \\ {[0.122]} & {[0.219]}\end{array}$

$0.10 \quad 0.08$

$[0.042]^{*} \quad[0.064]$

$0.12 \quad 0.06$

[0.120] [0.182]

$[0.065] \quad[0.092]$

$\begin{array}{ll}0.05 & 0.04\end{array}$

[0.053] [0.073]

$0.09 \quad 0.08$
0.050

[0.050] [0.073]

$\begin{array}{ll}-0.06 & -0.06\end{array}$

$[0.048] \quad[0.075$

0.03

\begin{tabular}{cc}
0.03 & 0.03 \\
4,395 & 2,216 \\
\hline
\end{tabular}

[0.029]* [0.038]*

$0.04 \quad 0.05$
$0.009 *$

$[0.016]^{* *}[0.021]^{* *}$

$-0.01 \quad-0.01$

[0.010] [0.013]

$[0.020] \quad[0.031]$

$0.03 \quad 0.03$

$[0.010]^{* *} \quad[0.013]^{*}$

$0.08 \quad 0.10$

$[0.022]^{* *}[0.029]^{* *}$

$0.04 \quad 0.04$

$[0.013]^{* *} \quad[0.017]^{*}$

$0.06 \quad 0.05$

$[0.011]^{* *}[0.014]^{* *}$

$0.04 \quad 0.03$

$[0.011]^{* *} \quad[0.015]^{*}$

$-0.02 \quad-0.02$
$0.012]$

[0.012] [0.017]

$\begin{array}{ll}0.08 & 0.08\end{array}$

$\begin{array}{ll}0.08 & 720 \quad 8,004\end{array}$

$\begin{array}{ll}0.08 & 0.07\end{array}$

$[0.035]^{*} \quad[0.044]$

$0.05 \quad 0.05$

$[0.012]^{* *}[0.016]^{* *}$

$0.10 \quad 0.10$

$[0.020]^{* *}[0.025]^{* *}$

$0.00 \quad-0.01$

[0.012] [0.016]

$-0.01 \quad-0.01$
$0.024]$

[0.024] [0.036]

[0.012] [0.016]

$0.08 \quad 0.10$

$[0.026]^{* *}[0.034]^{* *}$

$0.04 \quad 0.04$

$[0.015]^{* *} \quad[0.020]$

$\begin{array}{ll}0.05 & 0.04\end{array}$

$[0.013]^{* *} \quad[0.017]^{*}$

$[0.014]^{* *} \quad[0.018]$

$[0.018$

$0.07 \quad[0.021$

$\begin{array}{ll}0.07 & 0.07 \\ 9,325 & 5,788\end{array}$

$[0.009]^{* *}[0.013]^{* *}$

$0.10 \quad 0.11$

$[0.015] \quad[0.021]$
In-House

No Yes

(11) (12)

$0.16 \quad 0.04$
$[0.036] *$

$[0.036]^{* *} \quad[0.049]$

$0.010]^{* *} \quad[0.015]^{* *}$

$\begin{array}{ll}0.02 & 0.02\end{array}$

[0.012] [0.018]

$-0.02 \quad-0.04$
$[0.038]$

[0.038] [0.062]

$\begin{array}{ll}-0.01 & 0.00\end{array}$

[0.011] [0.016

$0.07 \quad 0.03$

$[0.022]^{* *} \quad[0.032$

$\begin{array}{ll}-0.02 & -0.02\end{array}$

[0.011] [0.016]

$[0.035]-0.00$

$\begin{array}{cc}{[0.035]} & {[0.062} \\ 0.00 & 0.00\end{array}$

[0.012] [0.018]

$\begin{array}{ll}0.06 & 0.07\end{array}$

[0.035] [0.051]

$-0.02 \quad-0.01$
$[0.019$

[0.019] [0.026]

$\begin{array}{ll}-0.02-0.00 \\ {[0.015]} & 0.020\end{array}$

$[0.015] \quad[0.020]$

$0.00 \quad-0.01$

[0.014] [0.021]

$-0.01 \quad-0.02$

[0.014] [0.021]

$\begin{array}{cc}0.02 & 0.01 \\ 4,395 & 2,216\end{array}$ 
Table 7: Who Makes Campaign Contributions to Whom?

The Role of Party and House/Senate Links

Dependent Variable: Lobbyist Makes at Least One Campaign Contribution to that Legislator in that Congress

\section{Congress:}

Republican Congressman

Republican Lobbyist

Republican Congressman*Republican Lobbyist

Democratic Lobbyist

Republican Congressman*Democratic Lobbyist

Senator

Lobbyist Has Senate Experience

Lobbyist Has House Experience

Senator*Lobbyist Has Senate Experience

House Representative*Lobbyist Has House Experience

Congressman Fixed Effects

Lobbyist Fixed Effects

R-squared

Observations

Standard errors are clustered at the lobbyist level.

$*$ significant at $5 \%$; ** significant at $1 \%$

\section{8th}

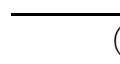

(2)

$-0.001$

$[0.0001]^{* *}$

$-0.002$

$[0.0003]^{* *}$

0.008

$[0.0006]^{* *}$

0.011

$[0.0008]^{* *}$

$-0.011$

$[0.0008]^{* *}$

0.004

$[0.0002]^{* *}$

$-0.0001$

[0.0004]

0.006

$[0.0020]^{* *}$

0.010

$[0.0009]^{* *}$

$-0.004$

[0.0015]*

No

$\mathrm{No}$

0.00

$4,575,967$

0.010

Yes

No

0.02
(3)

$-0.001$

$[0.0001]^{* *}$

$-0.002$

$[0.0003]^{* *}$

$0.008 \quad 0.008$

$[0.0006]^{* *} \quad[0.0006]^{* *}$

0.011

$[0.0008]^{* *}$

$-0.011$

$[0.0008]^{* *}$

$-0.011$

$[0.0008]^{* *}$

0.004

$[0.0002]^{* *}$

$-0.0001$

[0.0004]

0.006

$[0.0020]^{* *}$

$[0.0009]^{* *}$

$-0.004$

$[0.0015]^{*}$

$4,575,967$

$4,575,967$
0.010

$[0.0009]^{* *}$

$-0.004$

[0.0015]*

\begin{tabular}{|c|c|c|}
\hline \multicolumn{3}{|c|}{107 th } \\
\hline (4) & $(5)$ & (6) \\
\hline-0.0002 & & -0.0002 \\
\hline$[0.0001]^{*}$ & & {$[0.0001]^{*}$} \\
\hline-0.002 & -0.002 & \\
\hline$[0.0003]^{* *}$ & {$[0.0003]^{* *}$} & \\
\hline 0.007 & 0.007 & 0.007 \\
\hline$[0.0006]^{* *}$ & {$[0.0006]^{* *}$} & {$[0.0006]^{* *}$} \\
\hline 0.008 & 0.008 & \\
\hline$[0.0008]^{* *}$ & {$[0.0008]^{* *}$} & \\
\hline-0.009 & -0.009 & -0.009 \\
\hline$[0.0007]^{* *}$ & {$[0.0007]^{* *}$} & {$[0.0007]^{* *}$} \\
\hline 0.002 & & 0.002 \\
\hline$[0.0001]^{* *}$ & & {$[0.0001]^{* *}$} \\
\hline 0.0002 & 0.0002 & \\
\hline [0.0004] & [0.0004] & \\
\hline 0.007 & 0.007 & \\
\hline$[0.0022]^{* *}$ & {$[0.0022]^{* *}$} & \\
\hline 0.009 & 0.009 & 0.009 \\
\hline$[0.0009]^{* *}$ & {$[0.0009]^{* *}$} & {$[0.0009]^{* *}$} \\
\hline-0.004 & -0.004 & -0.004 \\
\hline$[0.0017]^{*}$ & {$[0.0017]^{*}$} & {$[0.0017]^{*}$} \\
\hline No & Yes & No \\
\hline No & No & Yes \\
\hline 0.00 & 0.01 & 0.02 \\
\hline $3,979,756$ & $3,979,756$ & $3,979,756$ \\
\hline
\end{tabular}

$3,979,756$

$3,979,756$ 
Congress

Dependent V ariable:

Lobbyist made at least one campaign contribution to that Congressman in Congress $(t)$ ? $(\mathrm{Y}=1)$

Republican Lobbyist

Republican Congressman*Republican Lobbyist

Democratic Lobbyist

Republican Congressman*Democratic Lobbyist

Lobbyist Has Senate Experience

Senator*Lobbyist has Senate Experience

Lobbyist Has House Experience

House Representative*Lobbyist has House Experience

Republican Congressman

Senator

Constant

R-squared

Observations

Lobbyist F.E.

Congressman F.E.s 108th

Number of Issues Covered by the
Legislator in Congress ( $t)$ that the
Lobbyists Covers in Congress ( $t)$

(1)

(2)
Lobbyist Works on All the

Issues Covered by the

Legislator in Congress ( $t$ )

$$
(Y=1)
$$

(3)

(4)

0.913

$\begin{array}{ll}0.029 & 0.019\end{array}$
[0.0531]*

0.576

$[0.0538]^{* *}$

0.032

$[0.0032]^{* *}$

0.452

$[0.0542]^{* *}$

0.043

$[0.0036]^{* *}$

0.045

[0.0513]

0.299

$[0.0334]^{* *}$

0.312

[0.1726]

$-0.277$

$[0.0781]^{* *}$

0.435

[0.0261]**

0.036

$[0.0032]^{* *}$

0.038

$[0.0034]^{* *}$

0.304

$[0.0336]^{* *}$

$-0.279$

-0.279
$0.0782]^{* *}$

0.083

$[0.0010]^{* *}$

0.828

$[0.0102]^{* *}$

1.0338

$[0.0138]^{* *}$

0.21

4,575,967

No

0.9766

$[0.0027]^{* *}$

0.42

4,575,967

Yes
$[0.0024]^{* *}[0.0031]^{* *}$

0.014

$[0.0018]^{* *}$

$\begin{array}{ll}0.001 & 0.001\end{array}$

$[0.0002]^{* *} \quad[0.0002]^{* *}$

0.014

$[0.0019]^{* *}$

$0.001 \quad 0.001$

$[0.0002]^{* *}[0.0002]^{* *}$

0.004

[0.0023]

$-0.014$

$[0.0020]^{* *}$

$-0.009$

$[0.0010]^{* *}$

0.010

[0.0046]*

0.019

0.019
$[0.0001]^{*}$

$-0.102$

$[0.0007]^{* *}$
$0.1116 \quad 0.1235$

$[0.0006]^{* *} \quad[0.0002]^{* *}$

0.76

0.04

$4,575,967$

$\mathrm{No}$

575,967

Yes
107 th

Number of Issues Covered by the Legislator in Congress (t) that the Lobbyists Covers in Congress ( $t)$$$
\text { (5) }
$$

(6)

\subsection{3}

$[0.0670]^{* *}$

0.519

$[0.0616]^{* *}$

0.019

$[0.0028]^{* *}$

0.521

$[0.0641]^{* *}$

0.037

$[0.0034]^{* *}$

0.088

[0.0589]

0.326

$[0.0383]^{* *}$

0.205

[0.1767]

$-0.228$

$[0.0795]^{* *}$

\subsection{0}

[0.0361]**

0.023

$[0.0028]^{* *}$

0.031

[0.0031]**

0.331

[0.0384]**

$-0.230$

$[0.0798]^{* *}$

0.056

[0.0008]**

0.850

$[0.0115]^{* *}$

1.049

1.0088

[0.0152] $]^{* *}$

[0.0030]**

0.23

0.39

3,979,756

3,979,756

No
Lobbyist Works on All the

Issues Covered by the

Legislator in Congress ( $t$ ) $(Y=1)$

$$
\text { (7) (8) }
$$

Yes
No $\begin{array}{ll}0.024 & 0.017\end{array}$

$[0.0027]^{* *}[0.0039]^{* *}$

0.011

$[0.0018]^{* *}$

$0.002 \quad 0.002$

$[0.0003]^{* *}[0.0003]^{* *}$

0.013

$[0.0018]^{* *}$

$0.002 \quad 0.002$

$[0.0003]^{* *}[0.0003]^{* *}$

0.003

[0.0022]

$\begin{array}{ll}-0.012 \quad-0.012 \\ {[0.0020]+*} & 0.00201 * *\end{array}$

$[0.0020]^{* *}[0.0020]^{* *}$

$-0.008$

$[0.0010]^{* *}$

$0.010 \quad 0.010$

$[0.0042]^{*} \quad[0.0042]^{*}$

0.048

$0.0001]^{* *}$
-0.101

$[0.0007]^{* *}$

$0.1386 \quad 0.1342$

$[0.0006]^{* *}[0.0001]^{* *}$

$\begin{array}{ll}0.81 & 0.03\end{array}$

3,979,756 3,979,756

No Yes

Ctandard errors are clustered at the lobbyist level.

* significant at $5 \%$; ** significant at $1 \%$ 
Table 9: Do Connections through Campaign Contributions Predict Overlapping Issues between Lobbyists and Congressmen? Heterogeneity of Effect Across Lobbyists and Congressmen

Sample:

Lobbyist is a Former
Member of Congress? External Lobbyist?

Congressman is Lobbyist is Connected

Member of Congress? External Lobbyist? Specialist?

connected to at least to at least 5 Members

$\begin{array}{lllllllll}\text { Yes } & \text { No } & \text { Yes } & \text { No } & \text { Yes } & \text { No } & \text { Yes } & \text { No } & \text { Yes }\end{array}$

(1) (2)

(3)

(4)

(5)

(6)

(7)

(8)

(9)

Lobbyist made at least one campaign contribution to that

Congressman in Congress $(t)$ ? $(\mathrm{Y}=1)$

\begin{tabular}{|c|c|c|c|c|c|c|c|c|c|}
\hline 0.0373 & 0.0317 & 0.039 & 0.0057 & 0.0604 & 0.0256 & 0.034 & 0.0302 & 0.0202 & 0.0163 \\
\hline$[0.0093]^{* *}$ & {$[0.0025]^{* *}$} & {$[0.0028]^{* *}$} & [0.0034] & {$[0.0066]^{* *}$} & {$[0.0024]^{* *}$} & {$[0.0027]^{* *}$} & {$[0.0031]^{* *}$} & {$[0.0025]^{* *}$} & {$[0.0027]^{* *}$} \\
\hline Yes & Yes & Yes & Yes & Yes & Yes & Yes & Yes & Yes & Yes \\
\hline 0.75 & 0.76 & 0.76 & 0.76 & 0.8 & 0.76 & 0.52 & 0.8 & 0.77 & 0.76 \\
\hline 74,752 & $4,509,064$ & $2,310,888$ & $2,272,928$ & $1,129,456$ & $3,454,360$ & 784,900 & $3,798,916$ & 602,104 & $3,981,712$ \\
\hline
\end{tabular}

Congressman F.E.s

07th Congress

R-squared

Observations

$$
\text { 107th Congress }
$$

Sample:

\section{Lobbyist is a Former}

Member of Congress? External Lobbyist?

Yes No Yes No

Lobbyist is a

Congressman is

Lobbyist is Connected

Specialist?

connected to at least

to at least 5 Members

\begin{tabular}{ccrrr}
\multicolumn{2}{c}{ Specialist? } & \multicolumn{2}{c}{40 Lobbyists? } & \multicolumn{2}{c}{ of Congress? } \\
Yes No & Yes & No & Yes
\end{tabular}

Lobbyist made at least one campaign contribution to that

Congressman in Congress $(t)$ ? $(\mathrm{Y}=1)$

$\begin{array}{cccccccccc}0.0337 & 0.0252 & 0.0312 & 0.0057 & 0.0549 & 0.0185 & 0.0245 & 0.0277 & 0.0135 & 0.0125 \\ {[0.0087]^{* *}} & {[0.0028]^{* *}} & {[0.0030]^{* *}} & {[0.0044]} & {[0.0068]^{* *}} & {[0.0028]^{* *}} & {[0.0029]^{* *}} & {[0.0034]^{* *}} & {[0.0026]^{* *}} & {[0.0033]^{* *}}\end{array}$

Congressman F.E.s

R-squared

$0.81-0.81$

Observations

$\begin{array}{lccc}74,054 & 3,925,469 & 0.81 & 0.81 \\ 2,027,987 & 1,971,536\end{array}$

$\begin{array}{cc}0.84 & 0.81 \\ 943,885 & 3,055,638\end{array}$

Yes

$[0.0034]$

$\begin{array}{cc}\text { Yes } & \text { Yes }\end{array}$

Standard errors are clustered at the lobbyist level.

* significant at $5 \%$;* significant at $1 \%$ 
Table 10a: Do Lobbyists Follow Politicians They Are Connected to as Those Politicians Switch Committee Assignments: Dependent V ariable: Number of new issues for the legislator in Congress ( $t+1)$ that the Lobbyists covers in Congress ( $t+1)$

\begin{tabular}{|c|c|c|c|c|c|c|c|c|}
\hline & (1) & (2) & (3) & (4) & (5) & (6) & (7) & (8) \\
\hline \multicolumn{9}{|l|}{$\begin{array}{l}\text { Lobbyists made at least one campaign } \\
\text { contribution to that Congressman in }\end{array}$} \\
\hline Congress $(t) ?(\mathrm{Y}=1)$ & $\begin{array}{c}0.359 \\
{[0.046]^{* *}}\end{array}$ & $\begin{array}{c}0.342 \\
{[0.047]^{* *}}\end{array}$ & $\begin{array}{c}0.118 \\
{[0.043]^{* *}}\end{array}$ & $\begin{array}{c}0.201 \\
{[0.046]^{* *}}\end{array}$ & $\begin{array}{c}0.188 \\
{[0.044]^{* *}}\end{array}$ & $\begin{array}{c}0.100 \\
{[0.033]^{* *}}\end{array}$ & $\begin{array}{c}0.106 \\
{[0.033]^{* *}}\end{array}$ & $\begin{array}{c}0.306 \\
{[0.057]^{* *}}\end{array}$ \\
\hline \multicolumn{9}{|l|}{$\begin{array}{l}\text { Number of new issues for the legislator in } \\
\text { Congress }(t+1) \text { that the Lobbyist covers in }\end{array}$} \\
\hline Congress $(t)$ & $\begin{array}{c}0.64 \\
{[0.009]^{* *}}\end{array}$ & $\begin{array}{c}0.6 \\
{[0.011]^{* *}}\end{array}$ & $\begin{array}{c}0.587 \\
{[0.011]^{* *}}\end{array}$ & $\begin{array}{c}0.677 \\
{[0.013]^{* *}}\end{array}$ & $\begin{array}{c}0.676 \\
{[0.013]^{* *}}\end{array}$ & $\begin{array}{c}0.638 \\
{[0.008]^{* *}}\end{array}$ & $\begin{array}{c}0.637 \\
{[0.008]^{* *}}\end{array}$ & \\
\hline Specialist & & & $\begin{array}{c}-0.249 \\
{[0.033]^{* *}}\end{array}$ & $\begin{array}{c}-0.255 \\
{[0.054]^{* *}}\end{array}$ & $\begin{array}{c}-0.245 \\
{[0.055]^{* *}}\end{array}$ & & & \\
\hline Internal & & & $\begin{array}{c}0.063 \\
{[0.021]^{* *}}\end{array}$ & $\begin{array}{l}-0.008 \\
{[0.025]}\end{array}$ & $\begin{array}{c}0.044 \\
{[0.028]}\end{array}$ & & & \\
\hline Number of active congresses & & & $\begin{array}{c}0.21 \\
{[0.007]^{* *}}\end{array}$ & & & & & \\
\hline Average Lobbyist Revenue & & & $\begin{array}{c}0.00001 \\
{[0.000]^{* *}}\end{array}$ & & & & & \\
\hline Lobbyist is Former Congressman & & & & & $\begin{array}{c}0.112 \\
{[0.086]}\end{array}$ & & & \\
\hline $\begin{array}{l}\text { Number of issues covered by the legislator } \\
\text { in Congress }(t) \text { that the Lobbyists covers in }\end{array}$ & & & & & & & & \\
\hline Congress $(t)$ & & & & & & & $\begin{array}{c}-0.007 \\
{[0.001]^{* *}}\end{array}$ & \\
\hline $\begin{array}{l}\text { Interactions Party Affiliat. * Party in Power } \\
\text { (Full Set) }\end{array}$ & No & No & No & No & Yes & No & No & No \\
\hline Congress F.E.s & Yes & Yes & Yes & Yes & Yes & Yes & Yes & Yes \\
\hline Lobbyist F.E.s & No & No & No & No & No & Yes & Yes & Yes \\
\hline Congressman F.E.s & No & Yes & Yes & Yes & Yes & No & No & No \\
\hline Lobbyists.Info Sample & No & No & No & Yes & Yes & No & No & No \\
\hline Constant & 0.025 & 0.137 & -0.688 & 0.185 & 0.124 & 0.53 & 0.571 & 1.883 \\
\hline & [0.019] & {$[0.020]^{* *}$} & {$[0.036]^{* *}$} & {$[0.031]^{* *}$} & {$[0.034]^{* *}$} & {$[0.028]^{* *}$} & {$[0.028]^{* *}$} & {$[0.019]^{* *}$} \\
\hline R-squared & 0.57 & 0.58 & 0.6 & 0.68 & 0.68 & 0.67 & 0.67 & 0.18 \\
\hline Observations & 513,000 & 513,000 & 513,000 & 265,938 & 265,351 & 513,000 & 513,000 & 513,000 \\
\hline
\end{tabular}

Sample is restricted to Congressmen that switch committee assignments between two consecutive Congresses.

Standard errors are clustered at the lobbyist level. For computational reasons for each politician a sample of the 1000 closest lobbyists is considered.

* significant at $5 \%$;* significant at $1 \%$ 
Table 10b: Heterogeneity in Following Connected Politicians. Dependent Variable: Number of new issues for the legislator in Congress ( $t+1)$ that the Lobbyists covers in Congress $(t+1)$

Sample:

\begin{tabular}{|c|c|c|c|c|c|c|c|c|c|}
\hline \multicolumn{2}{|c|}{$\begin{array}{l}\text { Lobbyist is a } \\
\text { Specialist? }\end{array}$} & \multicolumn{2}{|c|}{ External Lobbyist? } & \multicolumn{2}{|c|}{$\begin{array}{l}\text { Congressman is } \\
\text { connected to at least } \\
40 \text { Lobbyists? }\end{array}$} & \multicolumn{2}{|c|}{$\begin{array}{c}\text { Congressman is a } \\
\text { Senator? }\end{array}$} & \multicolumn{2}{|c|}{$\begin{array}{c}\text { Congressman moves } \\
\text { into fewer than } 20 \\
\text { new issues? }\end{array}$} \\
\hline Yes & No & Yes & No & Yes & No & Yes & No & Yes & No \\
\hline (1) & (2) & (3) & (4) & (5) & (6) & (7) & (8) & (9) & (10) \\
\hline
\end{tabular}

Lobbyists made at least one

campaign contribution to that Congressman in Congress

$(t) ?(\mathrm{Y}=1)$

$\begin{array}{cccccccccc}0.028 & 0.105 & 0.101 & 0.175 & 0.104 & 0.04 & 0.106 & 0.115 & 0.094 & 0.046 \\ {[0.106]} & {[0.034]^{* *}} & {[0.034]^{* *}} & {[0.109]} & {[0.038]^{* *}} & {[0.053]} & {[0.043]^{*}} & {[0.043]^{* *}} & {[0.023]^{* *}} & {[0.184]}\end{array}$

Number of new issues for the

legislator in Congress $(t+1)$ that

the Lobbyist covers in Congress

$(t)$

$\begin{array}{cccccccccc}0.486 & 0.648 & 0.633 & 0.646 & 0.64 & 0.632 & 0.621 & 0.64 & 0.603 & 0.271 \\ {[0.035]^{* *}} & {[0.008]^{* *}} & {[0.011]^{* *}} & {[0.012]^{* *}} & {[0.008]^{* *}} & {[0.009]^{* *}} & {[0.010]^{* *}} & {[0.008]^{* *}} & {[0.007]^{* *}} & {[0.019]^{* *}}\end{array}$

Number of issues covered by

the legislator in Congress $(t)$

that the Lobbyists covers in

Congress $(t)$

$\begin{array}{cccccccccc}-0.01 & -0.006 & -0.009 & 0 & -0.011 & -0.004 & -0.015 & -0.004 & -0.002 & -0.1 \\ {[0.003]^{* *}} & {[0.001]^{* *}} & {[0.001]^{* *}} & {[0.001]} & {[0.001]^{* *}} & {[0.001]^{* *}} & {[0.001]^{* *}} & {[0.001]^{* *}} & {[0.001]^{* *}} & {[0.009]^{* *}} \\ \text { Yes } & \text { Yes } & \text { Yes } & \text { Yes } & \text { Yes } & \text { Yes } & \text { Yes } & \text { Yes } & \text { Yes } & \text { Yes } \\ \text { Yes } & \text { Yes } & \text { Yes } & \text { Yes } & \text { Yes } & \text { Yes } & \text { Yes } & \text { Yes } & \text { Yes } & \text { Yes } \\ 0.556 & 0.572 & 0.58 & 0.548 & 0.564 & 0.596 & 0.691 & 0.535 & 0.446 & 4.892 \\ {[0.091]^{* *}} & {[0.029]^{* *}} & {[0.042]^{* *}} & {[0.034]^{* *}} & {[0.028]^{* *}} & {[0.030]^{* *}} & {[0.031]^{* *}} & {[0.029]^{* *}} & {[0.017]^{* *}} & {[0.186]^{* *}} \\ 0.59 & 0.68 & 0.68 & 0.67 & 0.68 & 0.68 & 0.68 & 0.68 & 0.63 & 0.79 \\ 40,635 & 472,365 & 263,639 & 249,361 & 267,000 & 246,000 & 120,000 & 393,000 & 461,000 & 52,000\end{array}$

Congress F.E.s

Lobbyist F.E.s

Constant

R-squared

$40,635 \quad 472,365$

Sample is restricted to Congressmen that switch committee assignments between two consecutive Congresses.

Standard errors are clustered at the lobbyist level. For computational reasons for each politician a sample of the 1000 closest lobbyists is considered.

* significant at $5 \%$; ** significant at $1 \%$ 
Table 10c: Do Lobbyists Follow Freshmen They Are Connected to as Those Politicians Are Elected and Gain Committee Assignments? Dependent Variable: Number of issues for the legislator in Congress ( $t+1)$ that the Lobbyists covers in Congress ( $t+1)$

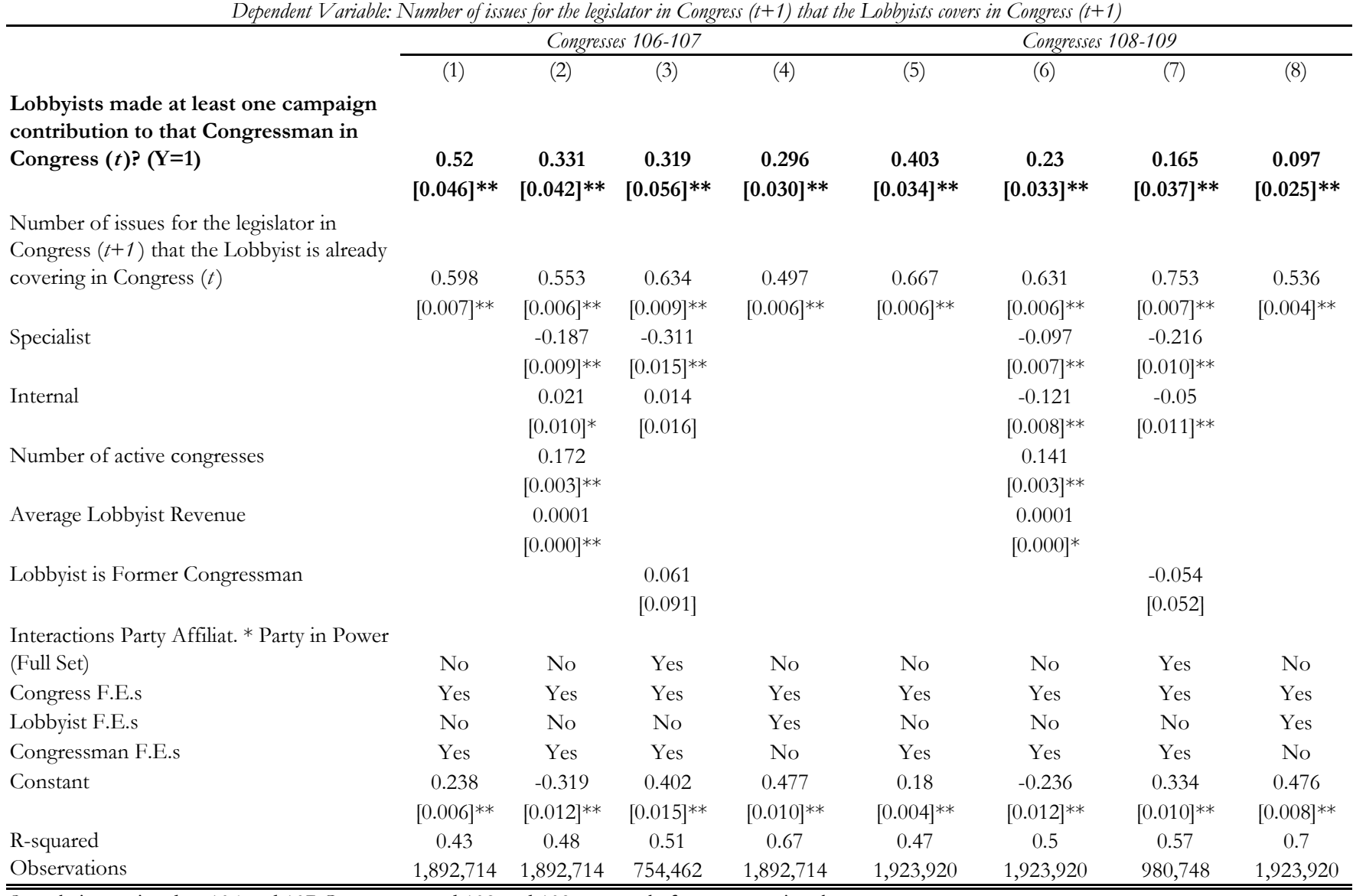

Sample is restricted to 106 and 107 Congresses and 108 and 109 separately for computational reasons.

Standard errors are clustered at the lobbyist level.

* significant at $5 \%$;* significant at $1 \%$ 
Table 11: Do Lobbyists Establish Connections (though Campaign Contributions) to Politicians as the Politicians are Assigned to the Lobbyists' Area of Expertise?

Dependent Variable:

Lobbyist made at least one campaign contribution to the Congressman in Congress ( $(t+1)(Y=1)$

(1)

$(2)$

(3)

(4)

(4)

(5)

(6)

(7)

(8)

(9)

$(10)$

(11)

Sample:

All

All

All

Lobbyist is a Specialist?

External Lobbyist?

Lobbyist is a Former

Congressman is

Number of issues covered by the

legislator in Congress $(t+1)$ that the

Lobbyists covers in Congress $(t)$

$\begin{array}{rrrrrrrrrrr}0.6882 & 0.6510 & 0.5926 & 0.6282 & 0.5893 & 1.0569 & 0.1821 & 2.1665 & 0.8904 & 0.8188 & 0.1616\end{array}$

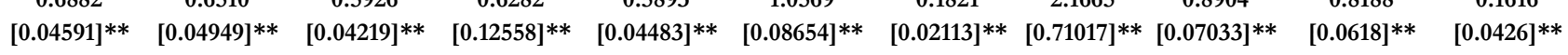

Lobbyist made at least one campaign contribution to that Congressman in

Congress $(t)$ ? $(\mathrm{Y}=1)$

Number of issues covered by the

legislator in Congress $(t)$ that the

Lobbyists covers in Congress $(t)$

$\begin{array}{ccccccccccc}0.2769 & 0.2762 & 0.2620 & 0.2992 & 0.2492 & 0.2723 & 0.2204 & 0.2951 & 0.2792 & 0.2432 & 0.3035 \\ {[0.0058]^{* *}} & {[0.0058]^{* *}} & {[0.0058]^{* *}} & {[0.0117]^{* *}} & {[0.0066]^{* *}} & {[0.0065]^{* *}} & {[0.0124]^{* *}} & {[0.0298]^{* *}} & {[0.0071]^{* *}} & {[0.0062]^{* *}} & {[0.012]^{* *}}\end{array}$

Congress F.E.s

Congressmen F.E.s

Lobbyist F.E.s

R-squared

$[0.0058]^{* *}$

$\begin{array}{cc}0.1115 & 0.1393 \\ {[0.03511]^{* *}} & {[0.03800]^{* *}}\end{array}$

0.0096

0.1228

$-0.0009$

$-0.0605$

$0.0628-1.0607$

$-0.0460$

$-0.2485$

0.0287

Yes Yes

No $\quad$ Yes

No No

$0.06 \quad 0.07$

Yes Yes

No No

Yes Yes

0.08

Yes
0.10

Yes

[0.07488] [0.02085

Yes $\quad$ [0.72557] $\quad[0.057$

[0.0543]

$[0.0423$

$3,758,268 \quad 3,758,268 \quad 3,758,268$

$1,073,836$

No No

Yes

No No No

Yes Yes Yes

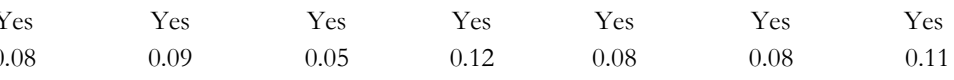

Yes

No

Sample is restricted to Congressmen that switch committee assionments between 107 and 108 Congresses for computational reasons.

Standard errors are clustered at the lobbyist level. Coefficients and s.e. for number of issues covered by the legislator in Congress $(t+1)$ and $(t)$ that the Lobbyists covers in Congress $(t)$ are $(\mathrm{x} 1000)$.

* significant at $5 \%$;* significant at $1 \%$ 
Table 12: Dollar Shares Across Lobbyists' Types

\begin{tabular}{|c|c|c|c|c|c|c|c|}
\hline \multicolumn{8}{|c|}{ Full Sample Shares } \\
\hline Year & & Total Lobbying & Connected & $\begin{array}{c}\text { Very } \\
\text { Connected }\end{array}$ & Specialist & $\begin{array}{l}\text { Not Connected } \\
\text { Specialist }\end{array}$ & $\begin{array}{c}\text { Connected } \\
\text { Not Specialist }\end{array}$ \\
\hline 1999 & $\$$ & $1,650,000,000$ & $37 \%$ & $14 \%$ & $22 \%$ & $13 \%$ & $28 \%$ \\
\hline 2000 & $\$$ & $1,760,000,000$ & $37 \%$ & $13 \%$ & $19 \%$ & $12 \%$ & $29 \%$ \\
\hline 2001 & $\$$ & $1,820,000,000$ & $38 \%$ & $14 \%$ & $19 \%$ & $11 \%$ & $30 \%$ \\
\hline 2002 & $\$$ & $2,040,000,000$ & $37 \%$ & $14 \%$ & $18 \%$ & $11 \%$ & $30 \%$ \\
\hline 2003 & $\$$ & $2,430,000,000$ & $42 \%$ & $17 \%$ & $18 \%$ & $10 \%$ & $34 \%$ \\
\hline 2004 & $\$$ & $2,420,000,000$ & $45 \%$ & $18 \%$ & $20 \%$ & $11 \%$ & $36 \%$ \\
\hline 2005 & $\$$ & $2,850,000,000$ & $43 \%$ & $18 \%$ & $21 \%$ & $11 \%$ & $34 \%$ \\
\hline 2006 & $\$$ & $3,300,000,000$ & $44 \%$ & $17 \%$ & $20 \%$ & $11 \%$ & $35 \%$ \\
\hline 2007 & $\$$ & $3,360,000,000$ & $47 \%$ & $19 \%$ & $23 \%$ & $12 \%$ & $37 \%$ \\
\hline 2008 & $\$$ & $3,040,000,000$ & $42 \%$ & $16 \%$ & $24 \%$ & $15 \%$ & $33 \%$ \\
\hline \multicolumn{8}{|c|}{ External Lobbyists Only Shares } \\
\hline 1999 & $\$$ & $909,000,000$ & $48 \%$ & $21 \%$ & $24 \%$ & $13 \%$ & $36 \%$ \\
\hline 2000 & $\$$ & $698,000,000$ & $57 \%$ & $27 \%$ & $27 \%$ & $13 \%$ & $42 \%$ \\
\hline 2001 & $\$$ & $777,000,000$ & $58 \%$ & $29 \%$ & $27 \%$ & $12 \%$ & $43 \%$ \\
\hline 2002 & $\$$ & $856,000,000$ & $57 \%$ & $27 \%$ & $26 \%$ & $12 \%$ & $43 \%$ \\
\hline 2003 & $\$$ & $1,060,000,000$ & $65 \%$ & $34 \%$ & $26 \%$ & $11 \%$ & $50 \%$ \\
\hline 2004 & $\$$ & $1,130,000,000$ & $65 \%$ & $34 \%$ & $28 \%$ & $12 \%$ & $48 \%$ \\
\hline 2005 & $\$$ & $1,330,000,000$ & $63 \%$ & $35 \%$ & $28 \%$ & $12 \%$ & $47 \%$ \\
\hline 2006 & $\$$ & $2,090,000,000$ & $56 \%$ & $25 \%$ & $23 \%$ & $11 \%$ & $43 \%$ \\
\hline 2007 & $\$$ & $2,330,000,000$ & $56 \%$ & $25 \%$ & $26 \%$ & $12 \%$ & $42 \%$ \\
\hline 2008 & $\$$ & $1,910,000,000$ & $54 \%$ & $24 \%$ & $26 \%$ & $13 \%$ & $41 \%$ \\
\hline
\end{tabular}

Notes: Shares of total lobbying amount reported by different types of lobbyists. 
Table 13: Valuing Expertise and Connections - Lobbying Report Analysis

External Lobbying Only

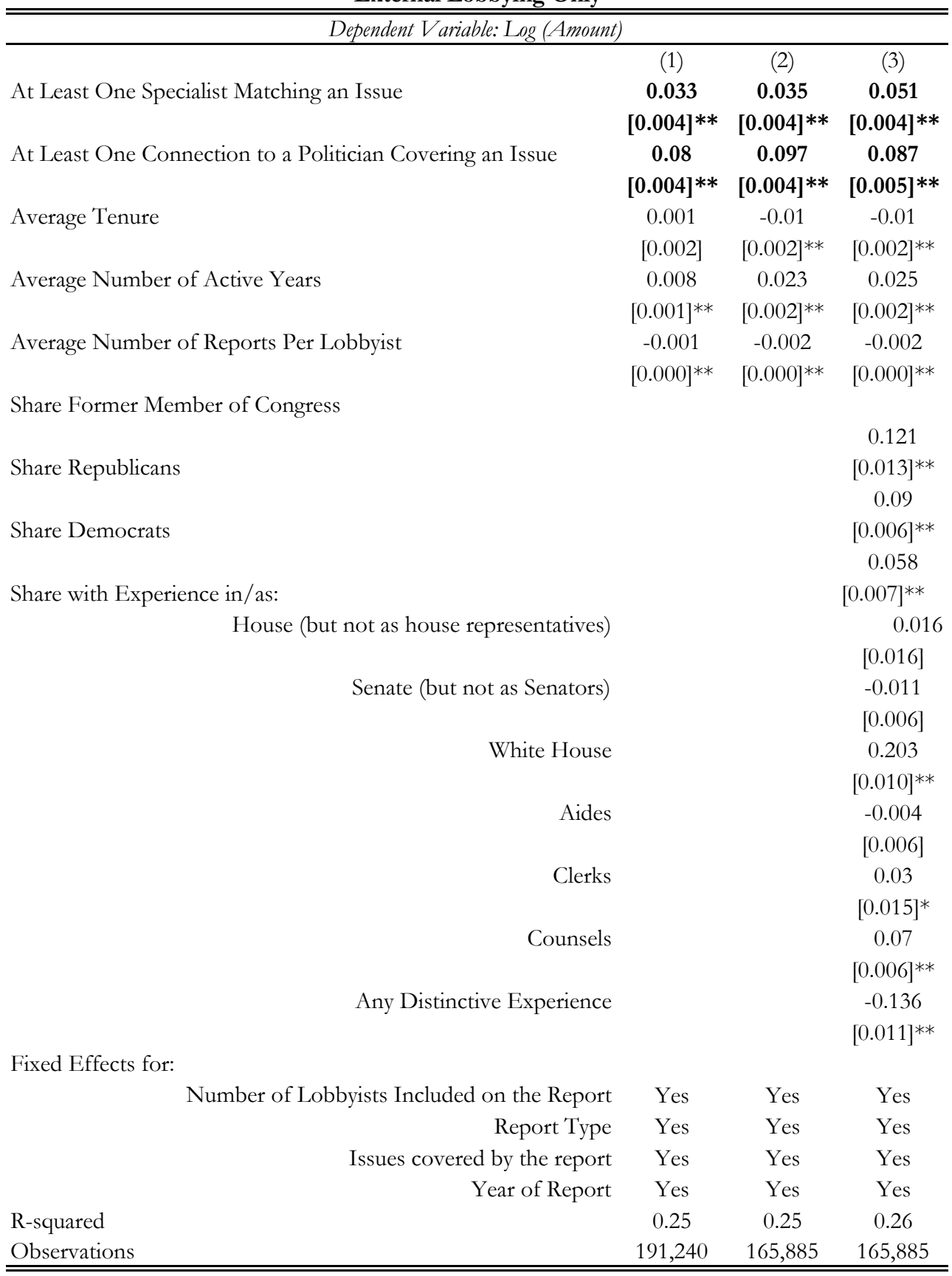

Clustered standard errors in brackets

* significant at 5\%; ** significant at $1 \%$

Also included are dummies for lobbyists' experience in the 1960s, 1970s, 1980s, 1990s and 2000s.

Any dinstinctive experience indicates any experience detail reported in the Lobbyists.info records. 
Table 14: Valuing Expertise and Connections - Lobbyist-Level Analysis

External Lobbyists with at least 6 Years of Active Experience Only

\begin{tabular}{|c|c|c|c|c|c|c|c|c|c|c|c|c|}
\hline \multicolumn{13}{|c|}{ Dependent Variable: Lobbyist's Estimated Fixed Effect } \\
\hline & (1) & (2) & (3) & (4) & (5) & $(6)$ & (7) & (8) & (9) & (10) & (11) & (12) \\
\hline \multirow[t]{2}{*}{ Issue-Based HHI } & -0.233 & -0.227 & -0.218 & -0.231 & -0.214 & -0.218 & & & & & & \\
\hline & {$[0.026]^{* *}$} & {$[0.029]^{* *}$} & {$[0.027]^{* *}$} & {$[0.023]^{* *}$} & {$[0.025]^{* *}$} & {$[0.029]^{* *}$} & & & & & & \\
\hline \multirow{2}{*}{ Specialist } & & & & & & & -0.012 & -0.016 & -0.005 & -0.02 & -0.027 & -0.009 \\
\hline & & & & & & & {$[0.017]$} & {$[0.019]$} & {$[0.022]$} & {$[0.017]$} & {$[0.021]$} & {$[0.020]$} \\
\hline \multirow[t]{2}{*}{ At Least One Connection } & 0.07 & 0.03 & 0.009 & & & & 0.095 & 0.062 & 0.043 & & & \\
\hline & {$[0.017]^{* *}$} & {$[0.020]$} & {$[0.019]$} & & & & {$[0.016]^{* *}$} & {$[0.019]^{* *}$} & {$[0.022]$} & & & \\
\hline \multirow[t]{2}{*}{ At Least Five Connections } & & & & 0.076 & 0.073 & 0.055 & & & & 0.098 & 0.094 & 0.073 \\
\hline & & & & {$[0.016]^{* *}$} & {$[0.017]^{* *}$} & {$[0.019]^{* *}$} & & & & {$[0.017]^{* *}$} & {$[0.020]^{* *}$} & {$[0.020]^{* *}$} \\
\hline \multirow[t]{2}{*}{ Number of Active Years } & -0.014 & -0.012 & -0.006 & -0.018 & -0.017 & -0.009 & -0.01 & -0.008 & -0.005 & -0.014 & -0.013 & -0.006 \\
\hline & {$[0.008]$} & {$[0.008]$} & {$[0.008]$} & {$[0.007]^{*}$} & {$[0.007]^{*}$} & {$[0.008]$} & {$[0.007]$} & {$[0.008]$} & [0.009] & {$[0.008]$} & [0.009] & {$[0.008]$} \\
\hline \multirow[t]{2}{*}{ Tenure } & 0.031 & 0.04 & 0.033 & 0.045 & 0.045 & 0.036 & 0.03 & 0.033 & 0.026 & 0.042 & 0.044 & 0.031 \\
\hline & {$[0.016]$} & {$[0.017]^{*}$} & {$[0.015]^{*}$} & {$[0.014]^{* *}$} & {$[0.014]^{* *}$} & {$[0.016]^{*}$} & {$[0.015]^{*}$} & {$[0.017]^{*}$} & [0.019] & {$[0.015]^{* *}$} & {$[0.018]^{*}$} & {$[0.017]$} \\
\hline \multirow[t]{2}{*}{ Former Memb. Of Congress } & & & 0.017 & & & 0.036 & & & 0.085 & & & 0.052 \\
\hline & & & {$[0.048]$} & & & {$[0.050]$} & & & {$[0.058]$} & & & [0.053] \\
\hline \multirow[t]{2}{*}{ Republican } & & & 0.039 & & & 0.032 & & & 0.061 & & & 0.071 \\
\hline & & & {$[0.024]$} & & & {$[0.025]$} & & & {$[0.028]^{*}$} & & & {$[0.026]^{* *}$} \\
\hline \multirow[t]{2}{*}{ Democrat } & & & 0.034 & & & 0.03 & & & 0.046 & & & 0.053 \\
\hline & & & {$[0.025]$} & & & {$[0.026]$} & & & [0.029] & & & {$[0.027]^{*}$} \\
\hline \multicolumn{13}{|l|}{ Experience in/as: } \\
\hline \multirow[t]{2}{*}{ House (but not as House Rep.) } & & & -0.012 & & & -0.024 & & & -0.001 & & & 0.016 \\
\hline & & & {$[0.061]$} & & & {$[0.064]$} & & & {$[0.074]$} & & & {$[0.067]$} \\
\hline \multirow[t]{2}{*}{ Senate (but not as Senator) } & & & 0.019 & & & 0.016 & & & 0.02 & & & 0.013 \\
\hline & & & {$[0.022]$} & & & {$[0.023]$} & & & {$[0.027]$} & & & {$[0.024]$} \\
\hline \multirow[t]{2}{*}{ White House } & & & 0.133 & & & 0.119 & & & 0.127 & & & 0.145 \\
\hline & & & {$[0.034]^{* *}$} & & & {$[0.036]^{* *}$} & & & {$[0.041]^{* *}$} & & & {$[0.038]^{* *}$} \\
\hline \multirow[t]{2}{*}{ Aide } & & & -0.048 & & & -0.045 & & & -0.03 & & & -0.03 \\
\hline & & & {$[0.022]^{*}$} & & & {$[0.023]$} & & & {$[0.027]$} & & & {$[0.024]$} \\
\hline \multirow[t]{2}{*}{ Clerk } & & & 0.108 & & & 0.133 & & & 0.103 & & & 0.11 \\
\hline & & & {$[0.047]^{*}$} & & & {$[0.049]^{* *}$} & & & {$[0.057]$} & & & {$[0.052]^{*}$} \\
\hline \multirow[t]{2}{*}{ Counsel } & & & 0.036 & & & 0.033 & & & 0.044 & & & 0.043 \\
\hline & & & {$[0.022]$} & & & {$[0.023]$} & & & {$[0.026]$} & & & {$[0.024]$} \\
\hline \multirow[t]{2}{*}{ Any Distinctive Experience } & & & -0.071 & & & -0.04 & & & -0.067 & & & -0.063 \\
\hline & & & {$[0.038]$} & & & {$[0.040]$} & & & {$[0.046]$} & & & {$[0.042]$} \\
\hline \multirow[t]{2}{*}{ Constant } & 15.055 & 15.027 & 15.064 & 15.067 & 15.052 & 15.044 & 14.928 & 14.924 & 14.959 & 14.964 & 14.953 & 14.968 \\
\hline & {$[0.040]^{* *}$} & {$[0.046]^{* *}$} & {$[0.056]^{* *}$} & {$[0.035]^{* *}$} & {$[0.039]^{* *}$} & {$[0.059]^{* *}$} & {$[0.036]^{* *}$} & {$[0.043]^{* *}$} & {$[0.066]^{* *}$} & {$[0.036]^{* *}$} & {$[0.046]^{* *}$} & {$[0.060]^{* *}$} \\
\hline Observations & 3,926 & 2,830 & 2,830 & 3,926 & 2,830 & 2,830 & 3,926 & 2,830 & 2,830 & 3,926 & 2,830 & 2,830 \\
\hline
\end{tabular}

Median regressions, Standard errors in brackets

* significant at $5 \%$; ** significant at $1 \%$

Each observation is weighted by the inverse of the standard error on the estimated fixed effects we use as dependent variable.

Also included are dummies for lobbyists' experience in the 1960s, 1970s, 1980s, 1990s and 2000s.

Any dinstinctive experience indicates any experience detail reported in the Lobbyists.info records. 
Table 15a: Issue Booms and Expertise - Issue Analysis

\begin{tabular}{lcc}
\hline \hline & Dependent Variable & \\
\hline & $\Delta$ Log total lobbyists in issue & Log total lobbyists in issue \\
& $(1)$ & $(2)$ \\
$\Delta$ Log total amount in issue & 0.501 & \\
& {$[0.062]^{* *}$} & 0.491 \\
Log total amount in issue & & {$[0.066]^{* *}$} \\
& & \\
Issue Specific Trend & No & Yes \\
Issue F.E.s & No & Yes \\
Observations & 684 & 760 \\
R-squared & 0.49 & 0.98 \\
\hline \hline
\end{tabular}

$\Delta$ Log total amount in issue $\quad-0.021$

$$
[0.007]^{* *}
$$

Log total amount in issue $\quad-0.022$

$[0.006]^{* *}$

Issue Specific Trend

Issue F.E.s

No Yes

Observations

No Yes

R-squared

684

760

Standard errors are clustered at the issue level.

* significant at 5\%; ** significant at $1 \%$

Table 15b: Issue Booms and Expertise - Lobbyist Analysis

\begin{tabular}{lcc}
\hline \hline & Dependent Variable & \\
\hline & Log per Lobbyist & Log per Lobbyist \\
& Amount & Amount \\
& $(1)$ & $(2)$ \\
$\mathrm{i}$ [Total amount in issue $\mathrm{i}$ *Specialist in issue i] & 0.000035 & \\
& {$[0.000097]$} & \\
$\Sigma \mathrm{i}[$ Log total amount in issue $\mathrm{i} *$ Specialist in issue i] & & -4254.96 \\
& & {$[9040.62]$} \\
Year F.E.s & Yes & Yes \\
Lobbyist F.E.s & Yes & Yes \\
Observations & 144,137 & 144,137 \\
R-squared & 0.48 & 0.48 \\
\hline \hline
\end{tabular}

Standard errors are clustered at the issue level.

* significant at 5\%; ** significant at $1 \%$ 
Figure 1A: Distribution of the Share of Specialists Across Lobbying Organizations

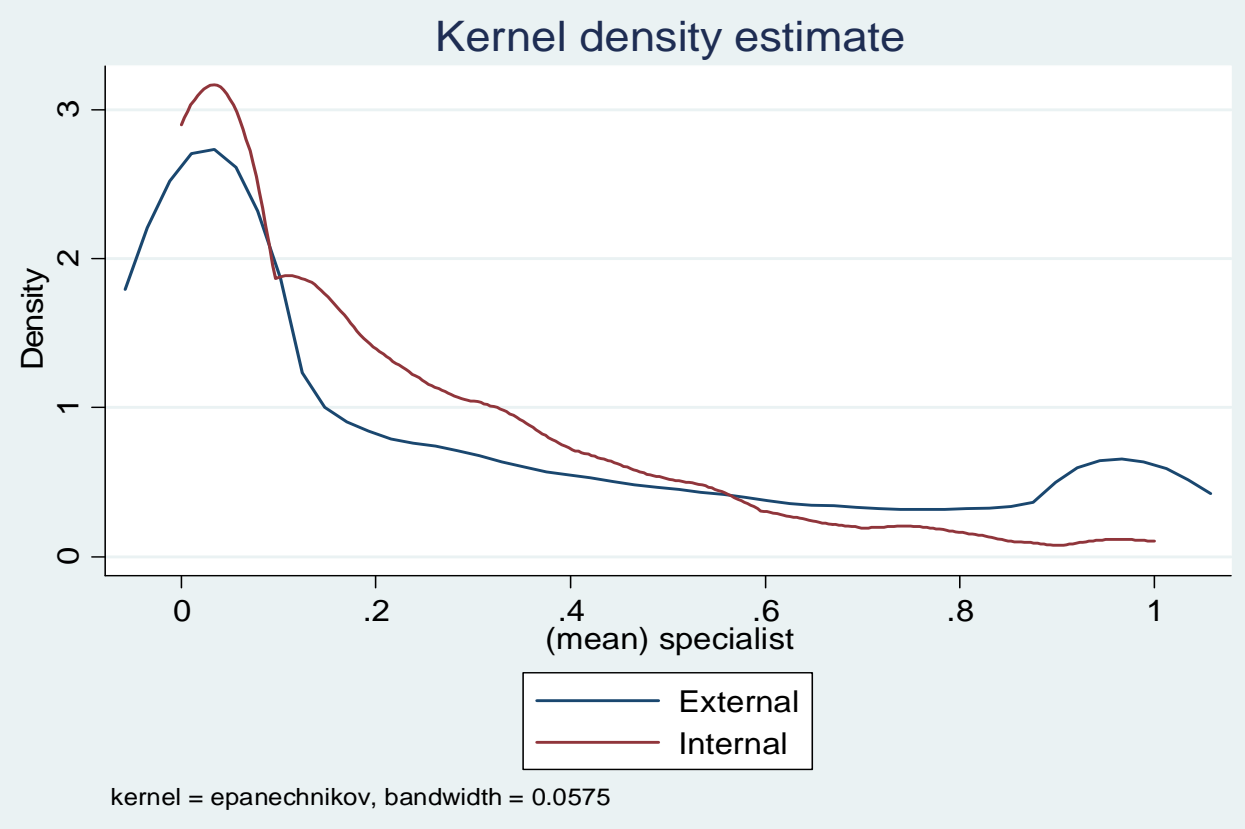

Figure 1B: Distribution of the Share of Lobbyists with at least one Connection to Politicians Across Lobbying Organizations

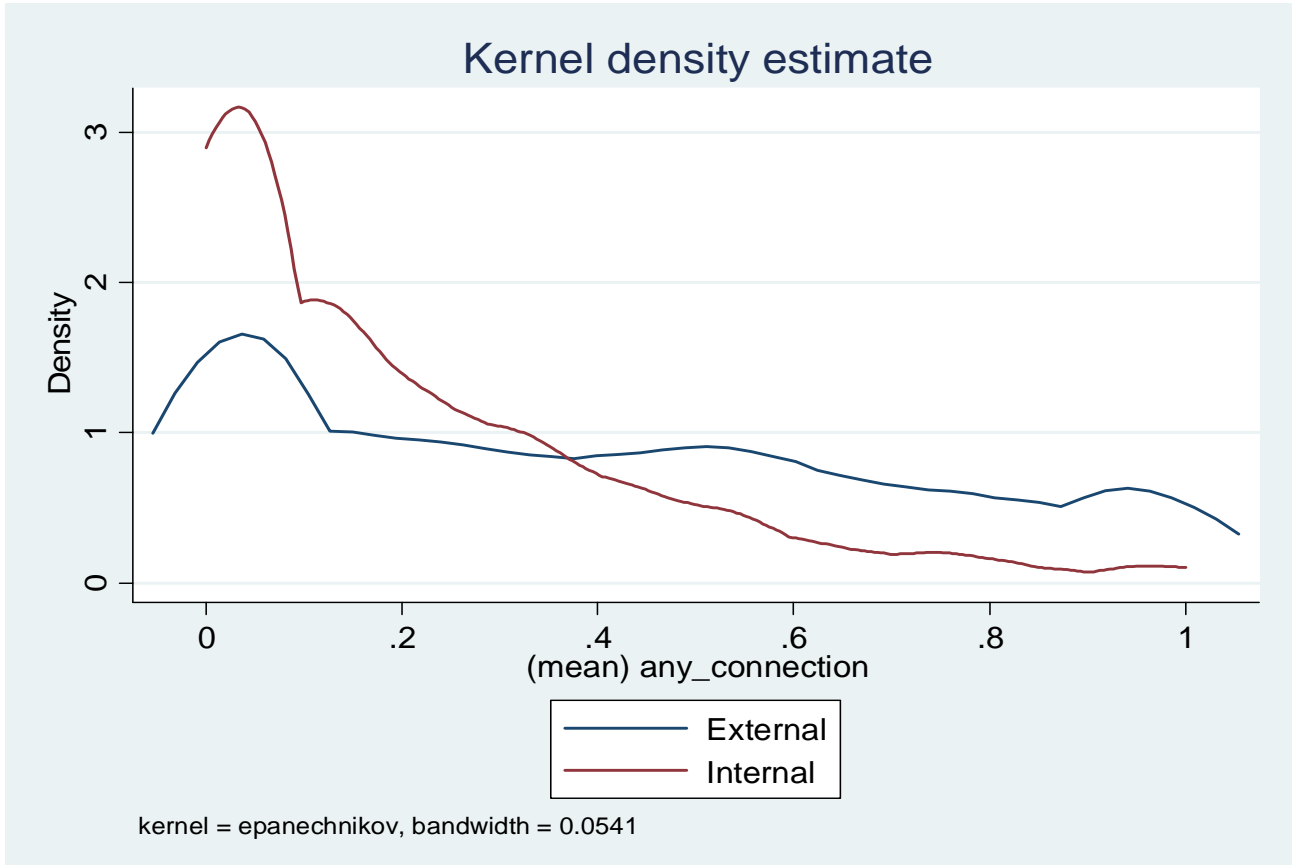

Note: :"External" refers to external lobbying; "Internal" refers to in-house lobbying. We restrict the sample to those organizations that employ at least 2 lobbyists over the sample period. See text for details. 
Figure 2: Distribution of External Lobbyists' Estimated Value Added by Level of Expertise

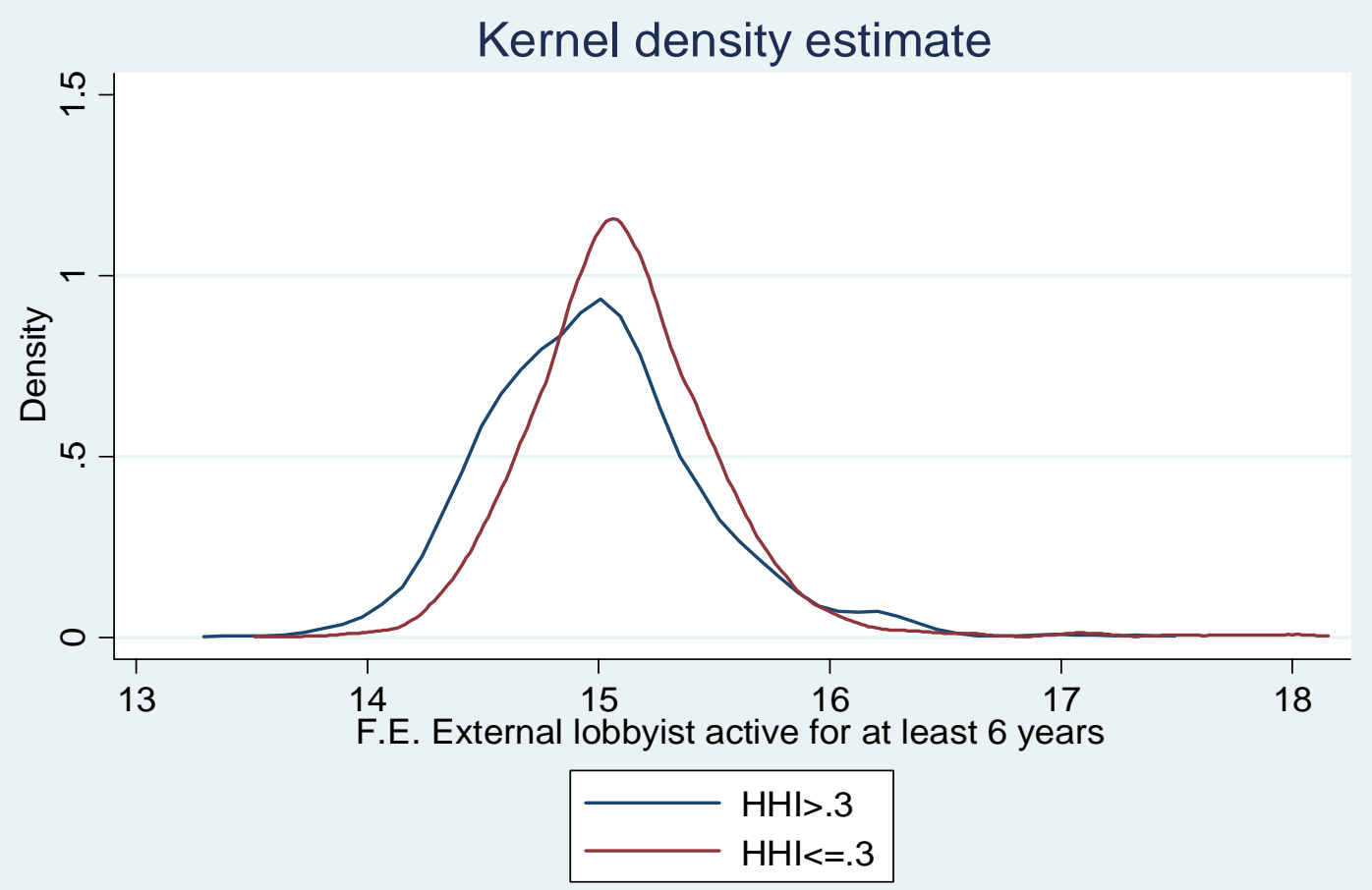

kernel $=$ epanechnikov, bandwidth $=0.0874$
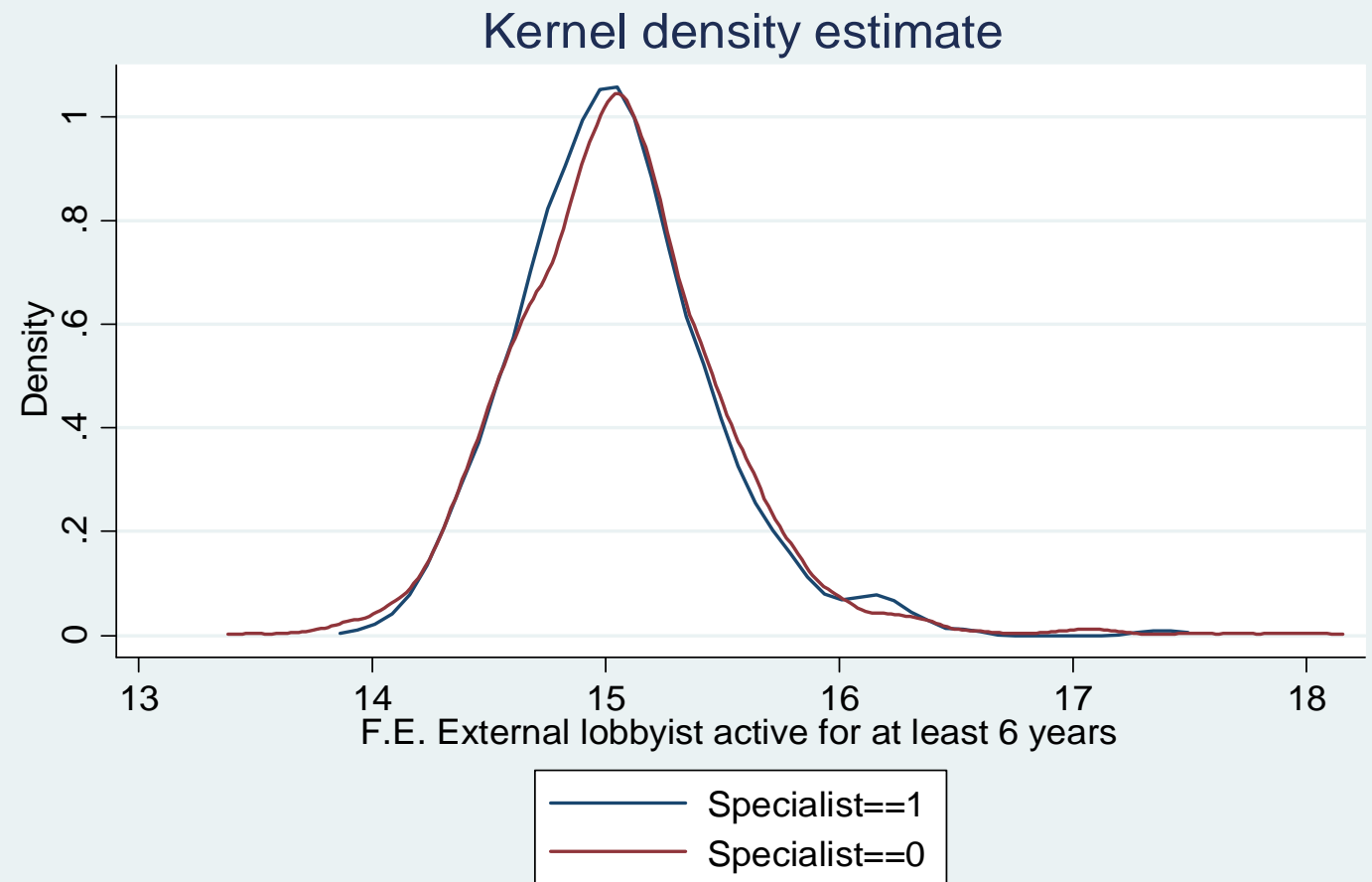

kernel $=$ epanechnikov, bandwidth $=0.0879$

Note: Lobbyists fixed effects were only computed for external lobbyists that are active in at least 6 out of the 10 sample years. See text for details. 
Figure 3: Distribution of External Lobbyists' Estimated Value Added By Level of Connections (through Campaign Contributions) to Politicians
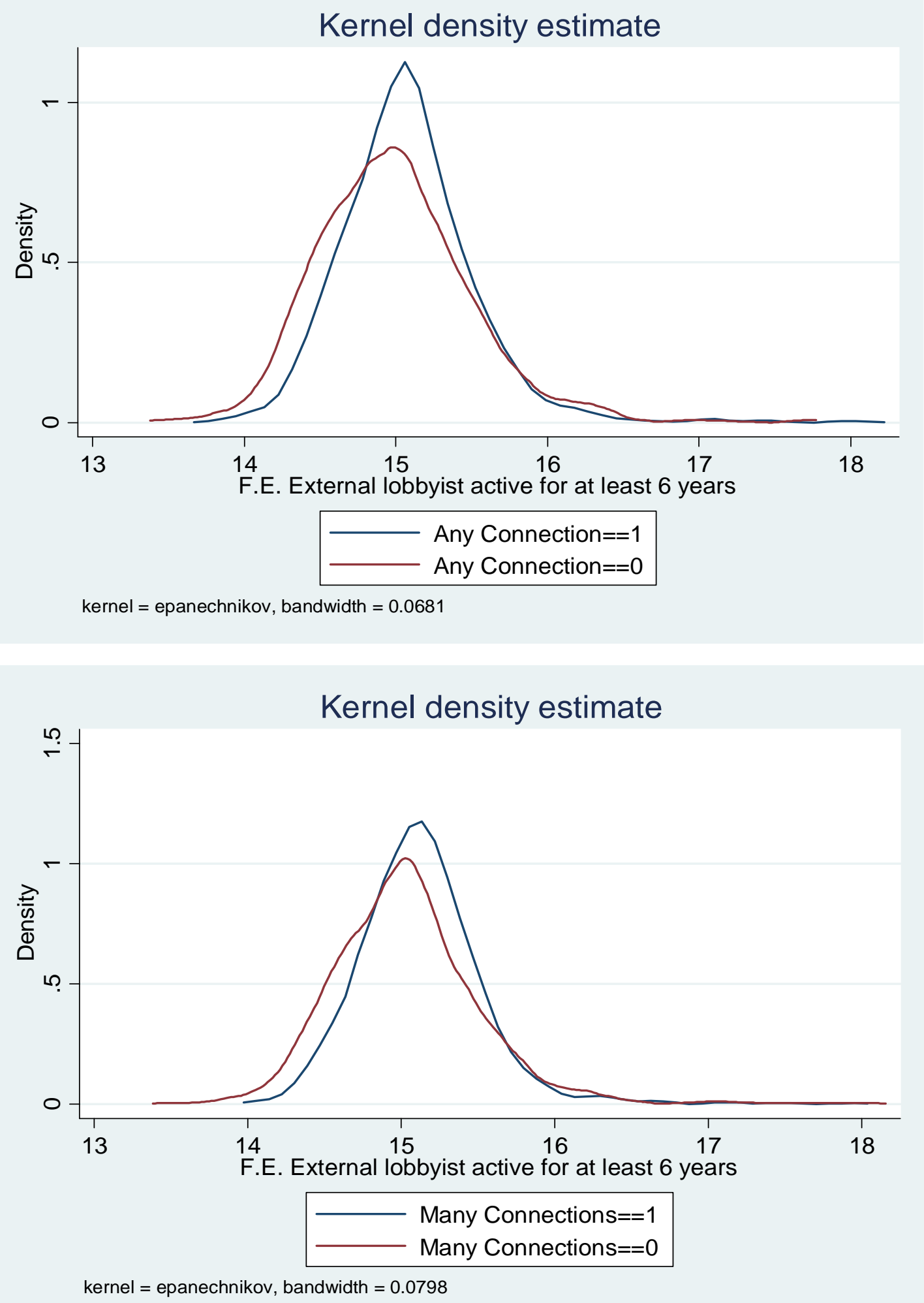

Note: Lobbyists fixed effects were only computed for external lobbyists that are active in at least 6 out of the 10 sample years. See text for details. 
Figure 4: Republican Lobbyist Revenue Premium

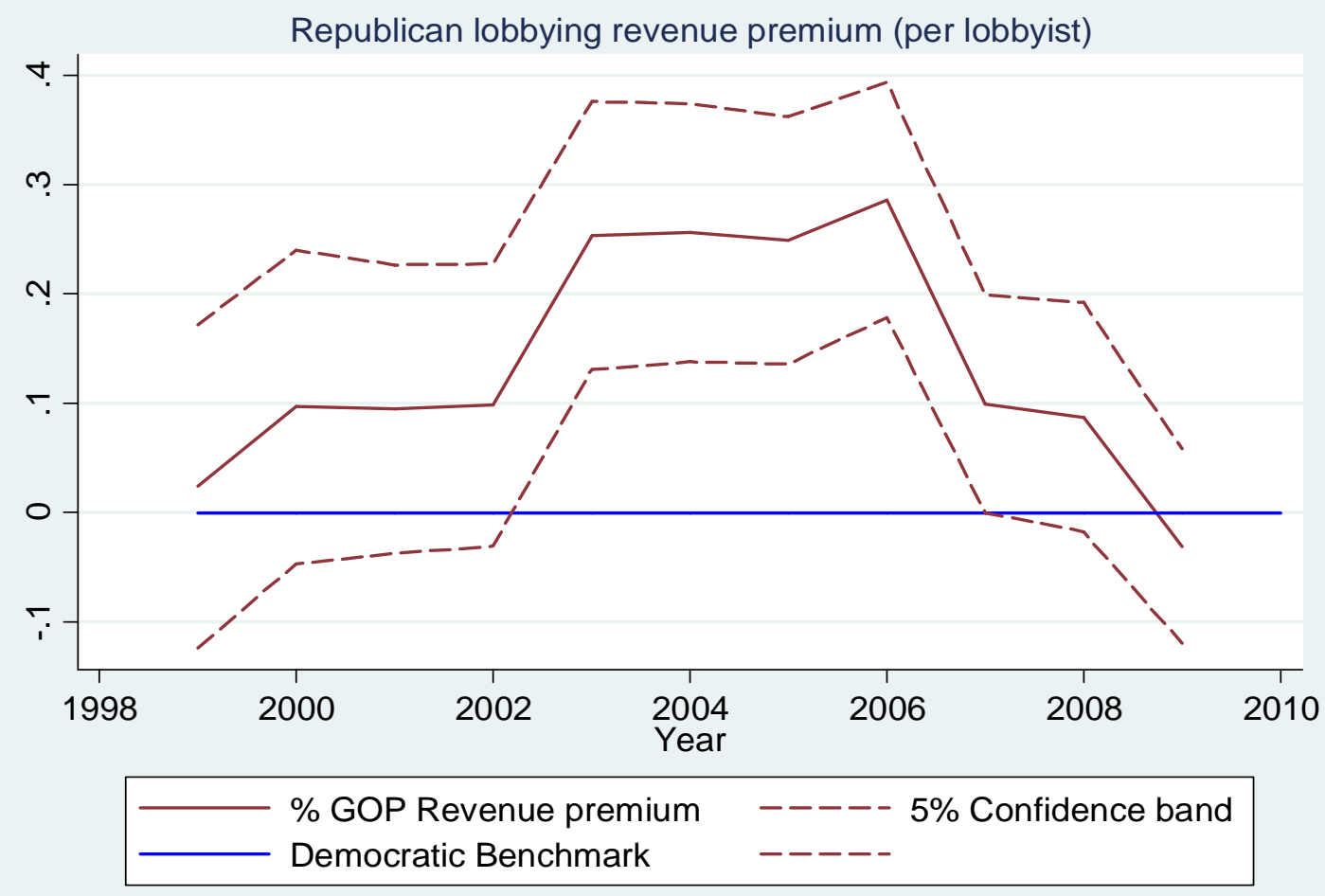


Appendix Table A1: Trends in Total Lobbying Expenses

\begin{tabular}{lccc}
\hline \hline Year & Internal & External & All \\
1999 & 1098 & 900 & 1994 \\
2000 & 1291 & 766 & 2055 \\
2001 & 1233 & 841 & 2072 \\
2002 & 1372 & 917 & 2288 \\
2003 & 1568 & 1098 & 2665 \\
2004 & 1443 & 1141 & 2584 \\
2005 & 1638 & 1303 & 2941 \\
2006 & 1526 & 1776 & 3303 \\
2007 & 1118 & 2145 & 3263 \\
2008 & 1122 & 1726 & 2847 \\
\hline \hline
\end{tabular}

Notes: All figures are in millions of 2006 dollars. 
Appendix Table A2: Political Cycles and Republican and Democratic Lobbyists

\begin{tabular}{lccccccc}
\hline \hline Year & \multicolumn{3}{c}{ Lobbying Expenses } & & \multicolumn{3}{c}{ Number of Lobbyists } \\
\cline { 2 - 3 } & Republican & Democratic & Gap & & Republican & Democratic & Gap \\
1999 & 127.84 & 113.86 & 13.98 & & 589 & 530 & 59 \\
2000 & 157.64 & 122.94 & 34.70 & & 619 & 556 & 63 \\
2001 & 167.53 & 152.00 & 15.53 & & 659 & 614 & 45 \\
2002 & 201.22 & 168.73 & 32.49 & & 711 & 646 & 65 \\
2003 & 262.22 & 209.42 & 52.80 & & 795 & 722 & 73 \\
2004 & 305.84 & 212.25 & 93.59 & & 881 & 766 & 115 \\
2005 & 373.71 & 263.05 & 110.66 & & 1022 & 848 & 174 \\
2006 & 521.13 & 293.00 & 228.13 & & 1110 & 920 & 190 \\
2007 & 449.21 & 370.07 & 79.14 & & 1178 & 1029 & 149 \\
2008 & 368.94 & 404.62 & -35.69 & & 1230 & 1097 & 133 \\
\hline \hline
\end{tabular}

Lobbying expenses are in millions of dollars. 


\begin{tabular}{|c|c|c|c|c|c|c|}
\hline Firm & Employee name & Position & Issue & Bar & $\begin{array}{c}\text { Issue- } \\
\text { specific } \\
\text { Training }\end{array}$ & $\begin{array}{c}\text { Registered } \\
\text { lobbyist }\end{array}$ \\
\hline Cassidy \& Assoc. & Boylan, John & $\begin{array}{l}\text { Senior Vice President } \\
\text { Founder \& Executive }\end{array}$ & aerospace & 0 & 1 & 1 \\
\hline Cassidy \& Assoc. & Cassidy, Gerald S. J. & $\begin{array}{l}\text { Chairman } \\
\text { Vice President and Deputy }\end{array}$ & aerospace & 1 & 0 & 1 \\
\hline Cassidy \& Assoc. & Edwards, Shawn & Director of Cassidy Defense & aerospace & 0 & 0 & 1 \\
\hline Cassidy \& Assoc. & Hegarty,Mark & Senior Vice President & aerospace & 0 & 1 & 1 \\
\hline Cassidy \& Assoc. & McNamara, Dan & Executive Vice President & aerospace & 0 & 0 & 1 \\
\hline Cassidy \& Assoc. & Meyers, George & $\begin{array}{l}\text { Vice President } \\
\text { Executive Vice President } \\
\text { and Director of Defense }\end{array}$ & aerospace & 0 & 1 & 1 \\
\hline Cassidy \& Assoc. & Paul, Terry & $\begin{array}{l}\text { Group } \\
\text { Senior Vice Chairman \& }\end{array}$ & aerospace & 0 & 1 & 1 \\
\hline Cassidy \& Assoc. & Russo, Marty & Chief Executive Officer & aerospace & 1 & 0 & 1 \\
\hline Cassidy \& Assoc. & Simmons, Vernon & Vice President & aerospace & 0 & 1 & 1 \\
\hline Cassidy \& Assoc. & Videnieks, Markus & Vice President & $\begin{array}{l}\text { aerospace } \\
\text { energy efficiency, power }\end{array}$ & 0 & 0 & 1 \\
\hline Cassidy \& Assoc. & Anderson, Kai & Executive Vice President & $\begin{array}{l}\text { storage, green buildings } \\
\text { energy efficiency, power }\end{array}$ & 0 & 1 & 1 \\
\hline Cassidy \& Assoc. & Burlij, Emily & Associate & $\begin{array}{l}\text { storage, green buildings } \\
\text { energy efficiency, power }\end{array}$ & 1 & 0 & 1 \\
\hline Cassidy \& Assoc. & Crespo, Jacqueline & Senior Associate & $\begin{array}{l}\text { storage, green buildings } \\
\text { energy efficiency, power }\end{array}$ & 0 & 1 & 0 \\
\hline Cassidy \& Assoc. & Dennis, Tom & Executive Vice President & storage, green buildings & 0 & 0 & 1 \\
\hline Cassidy \& Assoc. & Anderson, Kai & Executive Vice President & nuclear power & 0 & 1 & 1 \\
\hline Cassidy \& Assoc. & Burlij, Emily & Associate & nuclear power & 1 & 0 & 1 \\
\hline Cassidy \& Assoc. & Crespo, Jacqueline & Senior Associate & nuclear power & 0 & 1 & 0 \\
\hline Cassidy \& Assoc. & Dennis, Tom & Executive Vice President & nuclear power & 0 & 0 & 1 \\
\hline Cassidy \& Assoc. & Anderson, Kai & Executive Vice President & technology & 0 & 1 & 1 \\
\hline Cassidy \& Assoc. & Boylan, John & Senior Vice President & technology & 0 & 1 & 1 \\
\hline Cassidy \& Assoc. & Chapman, Justin & Account Coordinator & technology & 0 & 0 & 0 \\
\hline Cassidy \& Assoc. & Crespo, Jacqueline & Senior Associate & technology & 0 & 1 & 0 \\
\hline Cassidy \& Assoc. & Dennis, Tom & $\begin{array}{l}\text { Executive Vice President } \\
\text { Vice President and Deputy }\end{array}$ & technology & 0 & 0 & 1 \\
\hline Cassidy \& Assoc. & Edwards, Shawn & $\begin{array}{l}\text { Director of Cassidy Defense } \\
\text { Vice Chairman \& Chief }\end{array}$ & technology & 0 & 0 & 1 \\
\hline Cassidy \& Assoc. & Hartley, Gregg L. & Operating Officer & technology & 0 & 0 & 1 \\
\hline Cassidy \& Assoc. & Hegarty,Mark & Senior Vice President & technology & 0 & 1 & 1 \\
\hline & & Executive Vice President for & & & & \\
\hline Cassidy \& Assoc. & Hochstein, Amos & International Operations & technology & 0 & 0 & 1 \\
\hline Cassidy \& Assoc. & Ide, Betsy & Vice President & technology & 0 & 0 & 1 \\
\hline Cassidy \& Assoc. & Levy, Dawn & Senior Vice President & technology & 0 & 0 & 1 \\
\hline Cassidy \& Assoc. & McNamara, Dan & Executive Vice President & technology & 0 & 0 & 1 \\
\hline Cassidy \& Assoc. & Meyers, George & Vice President & technology & 0 & 1 & 1 \\
\hline Cassidy \& Assoc. & Neal, Laura & $\begin{array}{l}\text { Senior Vice President } \\
\text { Executive Vice President } \\
\text { and Director of Defense }\end{array}$ & technology & 0 & 0 & 1 \\
\hline Cassidy \& Assoc. & Paul, Terry & $\begin{array}{l}\text { Group } \\
\text { Senior Vice Chairman \& }\end{array}$ & technology & 0 & 1 & 1 \\
\hline Cassidy \& Assoc. & Russo, Marty & Chief Executive Officer & technology & 1 & 0 & 1 \\
\hline Cassidy \& Assoc. & Simmons, Vernon & Vice President & technology & 0 & 1 & 1 \\
\hline Cassidy \& Assoc. & Sutton, Barbara & Executive Vice President & technology & 0 & 0 & 1 \\
\hline Cassidy \& Assoc. & Temple, Roy & Senior Vice President & technology & 1 & 0 & 1 \\
\hline Patton Boggs LLP & Chambers, Scott & Partner & biotechnology & 1 & 1 & 0 \\
\hline Patton Boggs LLP & Chism, B. Dell & Patent Agent & biotechnology & 0 & 1 & 0 \\
\hline Patton Boggs LLP & McKeague, W. John & Associate & biotechnology & 1 & 1 & 0 \\
\hline
\end{tabular}




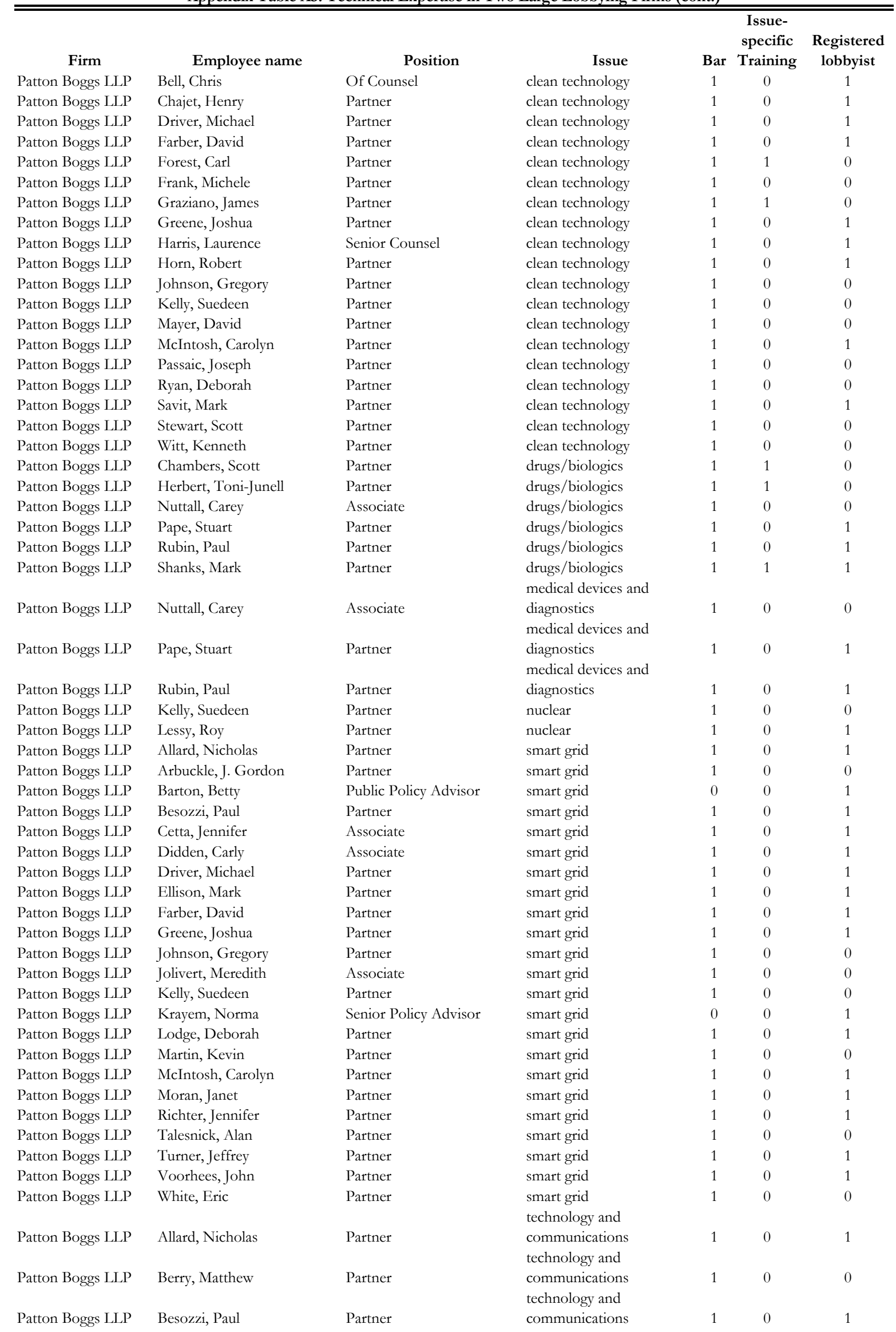




\begin{tabular}{|c|c|c|c|c|c|c|}
\hline Firm & Employee name & Position & Issue & Bar & $\begin{array}{c}\text { Issue- } \\
\text { specific } \\
\text { Training }\end{array}$ & $\begin{array}{c}\text { Registered } \\
\text { lobbyist }\end{array}$ \\
\hline Patton Boggs LLP & Bright, William & Public Policy Advisor & $\begin{array}{l}\text { technology and } \\
\text { communications } \\
\text { technology and }\end{array}$ & 1 & 0 & 1 \\
\hline Patton Boggs LLP & Cetta, Jennifer & Associate & $\begin{array}{l}\text { communications } \\
\text { technology and }\end{array}$ & 1 & 0 & 1 \\
\hline Patton Boggs LLP & Desai, Monica & Partner & $\begin{array}{l}\text { communications } \\
\text { technology and }\end{array}$ & 1 & 0 & 0 \\
\hline Patton Boggs LLP & Didden, Carly & Associate & $\begin{array}{l}\text { communications } \\
\text { technology and }\end{array}$ & 1 & 0 & 1 \\
\hline Patton Boggs LLP & Ellison, Mark & Partner & $\begin{array}{l}\text { communications } \\
\text { technology and }\end{array}$ & 1 & 0 & 1 \\
\hline Patton Boggs LLP & Forest, Carl & Partner & $\begin{array}{l}\text { communications } \\
\text { technology and }\end{array}$ & 1 & 1 & 0 \\
\hline Patton Boggs LLP & Gavin, Stephen Diaz & Partner & $\begin{array}{l}\text { communications } \\
\text { technology and }\end{array}$ & 1 & 0 & 1 \\
\hline Patton Boggs LLP & Graziano, James & Partner & $\begin{array}{l}\text { communications } \\
\text { technology and }\end{array}$ & 1 & 1 & 0 \\
\hline Patton Boggs LLP & Hager, Robert & Partner & $\begin{array}{l}\text { communications } \\
\text { technology and }\end{array}$ & 1 & 0 & 1 \\
\hline Patton Boggs LLP & Harris, Laurence & Senior Counsel & $\begin{array}{l}\text { communications } \\
\text { technology and }\end{array}$ & 1 & 0 & 1 \\
\hline Patton Boggs LLP & Ireland, Kathleen & Public Policy Counselor & $\begin{array}{l}\text { communications } \\
\text { technology and }\end{array}$ & 0 & 0 & 1 \\
\hline Patton Boggs LLP & Kim, Hwan & Partner & $\begin{array}{l}\text { communications } \\
\text { technology and }\end{array}$ & 1 & 0 & 0 \\
\hline Patton Boggs LLP & King, Ryan & Associate & $\begin{array}{l}\text { communications } \\
\text { technology and }\end{array}$ & 1 & 0 & 0 \\
\hline Patton Boggs LLP & Lane, Margaret & Senior Paralegal & $\begin{array}{l}\text { communications } \\
\text { technology and }\end{array}$ & 0 & 0 & 0 \\
\hline Patton Boggs LLP & Lodge, Deborah & Partner & $\begin{array}{l}\text { communications } \\
\text { technology and }\end{array}$ & 1 & 0 & 1 \\
\hline Patton Boggs LLP & Martin, Kevin & Partner & $\begin{array}{l}\text { communications } \\
\text { technology and }\end{array}$ & 1 & 0 & 0 \\
\hline Patton Boggs LLP & Moran, Janet & Partner & $\begin{array}{l}\text { communications } \\
\text { technology and }\end{array}$ & 1 & 0 & 1 \\
\hline Patton Boggs LLP & Reeder, James & Senior Counsel & $\begin{array}{l}\text { communications } \\
\text { technology and }\end{array}$ & 1 & 0 & 1 \\
\hline Patton Boggs LLP & Reisenfeld, Kenneth & Partner & $\begin{array}{l}\text { communications } \\
\text { technology and }\end{array}$ & 1 & 0 & 0 \\
\hline Patton Boggs LLP & Richter, Jennifer & Partner & $\begin{array}{l}\text { communications } \\
\text { technology and }\end{array}$ & 1 & 0 & 1 \\
\hline Patton Boggs LLP & Sachs, Lesley Bowling & Associate & $\begin{array}{l}\text { communications } \\
\text { technology and }\end{array}$ & 1 & 0 & 0 \\
\hline Patton Boggs LLP & Stolbach, Richard & Partner & $\begin{array}{l}\text { communications } \\
\text { technology and }\end{array}$ & 1 & 0 & 0 \\
\hline Patton Boggs LLP & Turner, Jeffrey & Partner & $\begin{array}{l}\text { communications } \\
\text { technology and }\end{array}$ & 1 & 0 & 1 \\
\hline Patton Boggs LLP & Yarowsky, Jonathan & Partner & communications & 1 & 0 & 1 \\
\hline
\end{tabular}

Notes: Employee listings and biographies as of November 2010. Bar indicates bar associaion membership.

Issue-specific training indicates the academic or professional technical background, including military.

Reference web pages: http://www.pattonboggs.com/attorneys/List.aspx and http://www.cassidy.com/team/ 


\section{Appendix A1: Lobbying Report Issue List}

\author{
ACC Accounting \\ ADV Advertising \\ AER Aerospace \\ AGR Agriculture \\ ALC Alcohol \& Drug Abuse \\ ANI Animals \\ APP Apparel/Clothing Industry/Textiles \\ ART Arts/Entertainment \\ AUT Automotive Industry \\ AVI Aviation/Aircraft/ Airlines \\ BAN Banking \\ BNK Bankruptcy \\ BEV Beverage Industry \\ BUD Budget/Appropriations \\ CHM Chemicals/Chemical Industry \\ CIV Civil Rights/Civil Liberties \\ CAW Clean Air \& Water (Quality) \\ CDT Commodities (Big Ticket) \\ COM Communications/ Broadcasting/Radio/TV \\ CPI Computer Industry \\ CSP Consumer Issues/Safety/ Protection \\ CON Constitution \\ CPT Copyright/Patent/ Trademark \\ DEF Defense \\ DOC District of Columbia \\ DIS Disaster Planning/Emergencies \\ ECN Economics/Economic Development \\ EDU Education \\ ENG Energy/Nuclear \\ ENV Environmental/Superfund \\ FAM Family Issues/Abortion/ Adoption \\ FIR Firearms/Guns/ Ammunition \\ FIN Financial Inst.s/Investments/Securities \\ FOO Food Industry (Safety, Labeling, etc.) \\ FOR Foreign Relations \\ FUE Fuel/Gas/Oil \\ GAM Gaming/Gambling/ Casino \\ GOV Government Issues
}

HCR Health Issues

HOU Housing

IMM Immigration

IND Indian/Native American Affairs

INS Insurance

LBR Labor Issues/Antitrust/ Workplace

LAW Law Enforcement/Crime/ Criminal Justice

MAN Manufacturing

MAR Marine/Maritime/ Boating/Fisheries

MIA Media (Information/ Publishing)

MED Medical/Disease Research/ Clinical Labs

MMM Medicare/Medicaid

MON Minting/Money/ Gold Standard

NAT Natural Resources

PHA Pharmacy

POS Postal

RRR Railroads

RES Real Estate/Land Use/Conservation

REL Religion

RET Retirement

ROD Roads/Highway

SCI Science/Technology

SMB Small Business

SPO Sports/Athletics

TAX Taxation/Internal Revenue Code

TEC Telecommunications

TOB Tobacco

TOR Torts

TRD Trade (Domestic \& Foreign)

TRA Transportation

TOU Travel/Tourism

TRU Trucking/Shipping

URB Urban Development/ Municipalities

UNM Unemployment

UTI Utilities

VET Veterans

WAS Waste (hazard/solid/interstate/nuclear)

WEL Welfare 


\section{Appendix A2: Sample Lobbying Report}

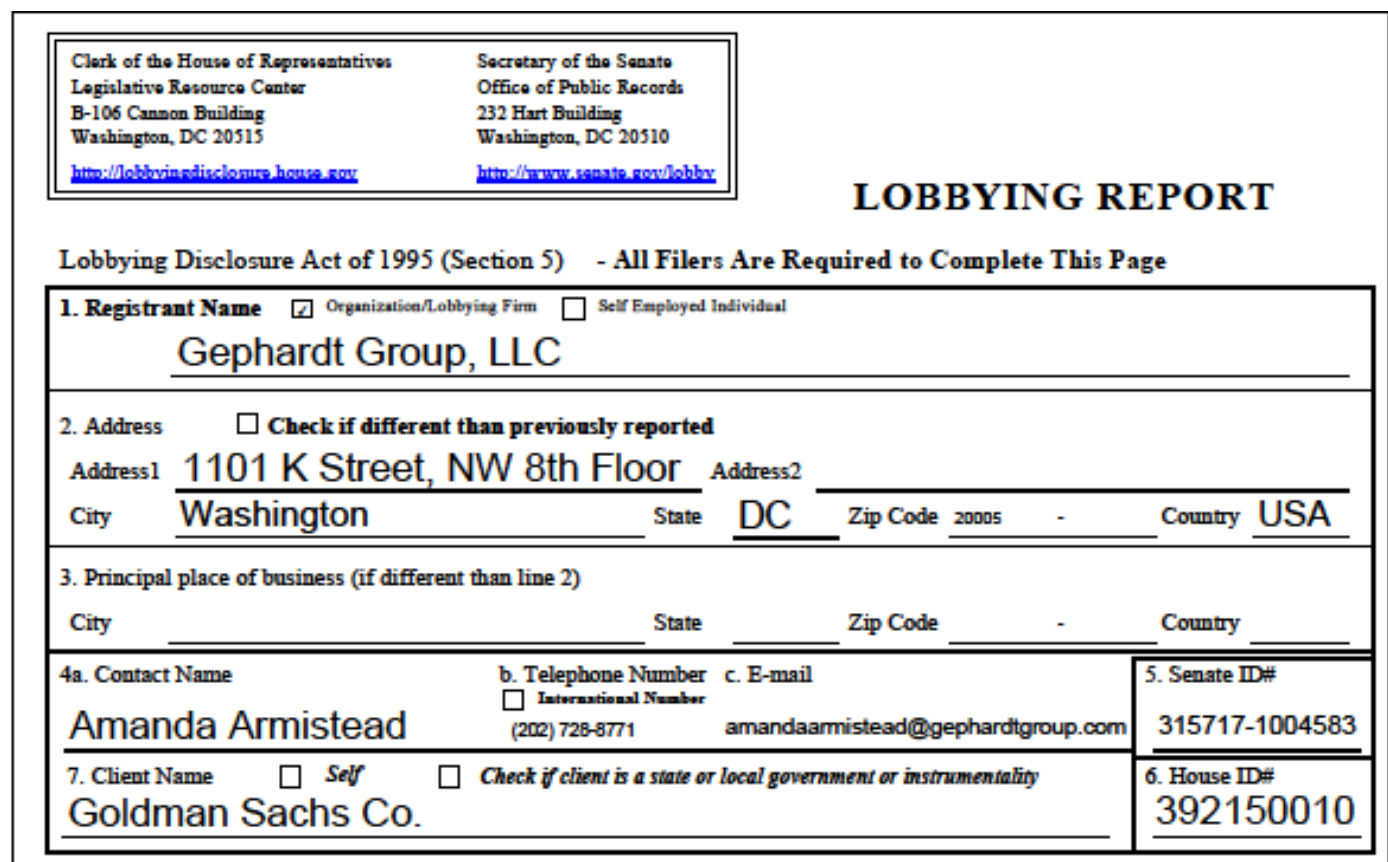

$\begin{array}{lllllll}\text { TYPE OF REPORT 8. Year } & 2008 \text { Q1 (1/1-3/31) } \square & \text { Q2 (4/1-6/30) } \square \quad \text { Q3 (7/1-9/30) } \square \quad \text { Q4 (10/1-12/31) } \square\end{array}$ 9. Check if this filing amends a previously filed version of this report
10. Check if this is a Termination Report
Termination Date
11. No Lobbying Issue Activity

INCOME OR EXPENSES - YOU MUST complete either Line 12 or Line 13

\begin{tabular}{l|l} 
12. Lobbying & 13. Organizations
\end{tabular}

INCOME relating to lobbying activities for this reporting period was:

Lens than $55000 \quad \square$

$\underline{\$ 5,000 \text { or more }} \quad \square \$ \$ 70,000.00$

Provide a good faith estimate, rounded to the nearest $\$ 10,000$, of all lobbying related income from the client (including all payments to the registrant by any other entity for lobbying activities on behalf of the client).

EXPENSE relating to lobbying activities for this reporting period were:

Lens than $\$ 5,000 \quad \square$

$\$ 5,000$ or moro $\square \$$

14. REPORTING Check box to indicate expense accounting method See instructions for description of options.

$\square$ Method A. Reporting amounts using LDA definitions only

$\square$ Method B. Roporting amounts under saction 6033(b)(8) of the Internal Revomuo Code

Method C. Roporting amounts under saction 162(0) of the Internal Rovomue Codo

Signature Fled Electronicaly

Date 01/15/2009

Printed Name and Title Amanda Armistead, Executive Assistant

-6.0.1f

Page 1 _ of 2 


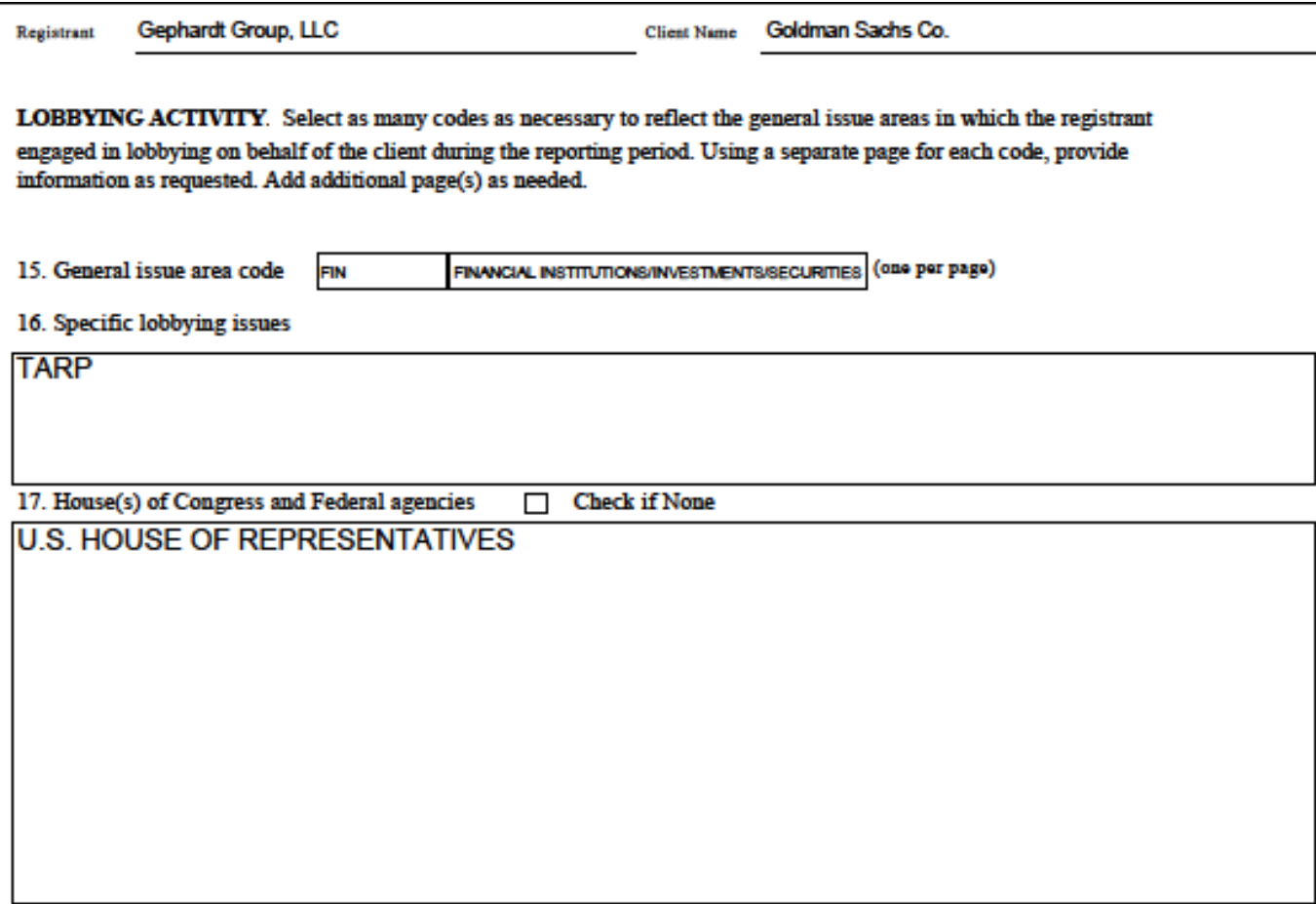

18. Name of each individual who acted as a lobbyist in this issue area

\begin{tabular}{|c|c|c|c|c|}
\hline First Name & Last Name & Suffix & Covared Official Position (if applicablo) & Now \\
\hline Thomas & ODomell & & & $\square$ \\
\hline \multirow[t]{8}{*}{ Fuchard } & Gephart: & & & $\square$ \\
\hline & & & & $\square$ \\
\hline & & & & $\square$ \\
\hline & & & & $\square$ \\
\hline & & & & $\square$ \\
\hline & & & & $\square$ \\
\hline & & & & $\square$ \\
\hline & & & & $\square$ \\
\hline
\end{tabular}

19. Interest of each foreign entity in the specific issues listed on line 16 above $\square$ Check if None

Printed Name and Title Amanda Armistead, Executive Assistant 


\title{
Appendix A3: Chamber, Congressional Committee, Lobbying Issues
}

\author{
House, Agriculture: AGR, FOO, TOB, ANI, CDT \\ House, Appropriations: BUD \\ House, Armed Services (103rd, 109-110th): AER, DEF, HOM, INT \\ House, National Security (104th - 108th): AER, DEF, HOM, INT \\ House, Banking, Finance and Urban Affairs (103rd): HOU, FIN, INS, RES, MON, BAN, BNK, URB, GAM \\ House, Banking and Financial Services (104th - 106th): HOU, FIN, INS, RES, TUE, BAN, BNK, URB, GAM \\ House, Financial Services (106th - 110th): HOU, FIN, INS, RES, WED, BAN, BNK, URB, GAM \\ House, Budget: BUD \\ House, District of Columbia (103rd): DOC \\ House, Education and Labor (103rd, 110th): EDU, FAM, LBR, RET, ALC, WEL, REL, ART \\ House, Economic and Educational Opportunities (104th): EDU, FAM, LBR, RET, ALC, WEL, REL, ART \\ House, Education and the Workplace (105th - 109th): EDU, FAM, LBR, RET, ALC, WEL, REL, ART \\ House, Energy and Commerce (103rd, 107th - 110th): ACC, CSP, ENG, TEC, FOO, FUE, ALC, MMM, MED, \\ ENV, SPO, TRD, TOU, HCR, CAW, WAS, UTI, PHA, MAN, ADV, MIA, CPI, COM, CDT, CHM, BEV, AUT, \\ APP \\ House, Commerce (104th - 106th): ACC, CSP, ENG, TEC, FOO, FUE, ALC, MMM, MED, ENV, SPO, TRD, \\ TOU, HCR, CAW, WAS, UTI, PHA, MAN, ADV, MIA, CPI, COM, CDT, CHM, BEV, AUT, APP \\ House, Foreign Affairs (103rd, 110th): FOR, ECN, REL \\ House, International Relations (104th - 109th): FOR, ECN, REL \\ House, Government Operations (103rd): GOV, POS, DOC \\ House, Government Reform and Oversight (104th - 109th): GOV, POS, DOC \\ House, Oversight and Government Reform (110th): GOV, POS, DOC \\ House, House Administration (103rd, 109-110th): GOV \\ House, House Oversight (104th - 108th): GOV \\ House, Judiciary: LAW, CON, CPT, IMM, CIV, TOR, FIR \\ House, Merchant Marine and Fisheries (103rd): MAR \\ House, Natural Resources (103rd, 110th): MAR, NAT, IND, RES, GAM, CDT \\ House, Resources (104h - 109th): APR, NAT, IND, RES, GAM, CDT \\ House, Post Office and Civil Service (103rd): POS \\ House, Public Works and Transportation (103rd): MAR, RRR, ROD, TRA, TRU, DIS \\ House, Transportation and Infrastructure (104th - 110th): APR, RRR, ROD, TRA, TRU, DIS \\ House, Rules, GOV \\ House, Science, Space, and Technology (103rd): ENG, SCI, AER, AVI, CPI \\ House, Science (104th - 109th): ENG, SCI, AER, AVI, CPI \\ House, Science and Technology (110th): ENG, SCI, AER, AVI, CPI \\ House, Small Business: SMB \\ House, Standards of Official Conduct: GOV \\ House, Veterans Affairs: VET \\ House, Ways and Means: UNM, TRD, TAX, WEL, RET \\ House, Intelligence (Select): INT, HOM \\ House, Homeland Security (Select 107th and 108th; Standing, 109th-110th): HOM \\ House, Energy Independence and Global Warming (Select, 110th): ENG, FUE, CDT, CAW, ENV \\ House, Investigate the Voting Irregularities of August 2, 2007 (Select, 110th): GOV \\ Senate, Agriculture, Nutrition, and Forestry: AGR, FOO, TOB, ANI, CDT \\ Senate, Appropriations: BUD \\ Senate, Armed Services: AER, DEF, HOM, INT
}


Senate, Banking, Housing, and Urban Affairs: HOU, URB, INS, RES, GAM, BAN, CDT, FIN, TRD, ECN, MON, BNK, ACC

Senate, Budget: BUD

Senate, Commerce, Science, and Transportation: AVI, ADV, AER, APP, AUT, COM, CPI, CSP, MAN, MAR, MIA, RRR, ROD, SCI, TEC, SPO, PHA, TRD, TRA, TOU, TRU, CHM, BEV

Senate, Energy and Natural Resources: ENG, NAT, FUE, WAS, CDT, UTI

Senate, Environment and Public Works: ENV, DIS, CAW, ROD, ECN, WAS

Senate, Finance: UNM, TRD, TAX, WEL, RET, MMM

Senate, Foreign Relations: FOR, ECN, REL

Senate, Governmental Affairs (103rd to 108th): GOV, HOM, INT, POS

Senate, Homeland Security and Governmental Affairs (109th): GOV, HOM, INT, POS

Senate, Judiciary: LAW, CON, CPT, IMM, CIV, TOR, FIR

Senate, Labor and Human Resources (103rd to 106th): EDU, FAM, LBR, RET, ALC, WEL, REL, ART, HCR, MED

Senate, Health, Education, Labor, and Pensions (107th to 109th): EDU, FAM, LBR, RET, ALC, WEL, REL, ART, HCR, MED

Senate, Rules and Administration: GOV

Senate, Small Business (103rd to 107th): SMB

Senate, Small Business and Entrepreneurship (108th and 109th): SMB

Senate, Veterans Affairs: VET

Senate, Aging (Special): RET, HCR

Senate, Intelligence (Select): INT, HOM

Senate, Ethics (Select): GOV

Senate, Indian Affairs (Select): IND, GAM

Joint, Library: GOV

Joint, Printing: GOV

Joint, Taxation: TAX

Joint, Economic: ECN 